CENTRE FOR COMPARATIVE ECONOMICS

E\&BWP

\author{
UCL SSEES \\ Centre for Comparative Economics
}

\title{
Corruption and Management Practices Firm Level Evidence
}

\author{
Daphne Athanasoulia \\ Antoine Goujard ${ }^{b}$ \\ ${ }^{a}$ University College London, UK \\ ${ }^{b} \mathrm{OECD}$, Economics Department
}

Economics and Business Working Paper No.121

January 2013

Centre for Comparative Economics UCLSchool of Slavonic and East European Studies Gower Street, London, WC1E 6BT Tel: +44 (0)20 76798519 Fax: +44 (0)20 76798777 


\title{
Corruption and management practices Firm level evidence
}

\author{
Daphne Athanasouli, Antoine Goujard* \\ January 2013
}

\begin{abstract}
We argue that corruption can decrease aggregate productivity by deteriorating firm management practices. We investigate the impact of regional corruption on the management quality of firms within the manufacturing sector in Central and Eastern Europe. To do this we construct a new data set merging a survey of firm management practices and regional measures of corruption from population and firm surveys. The empirical challenge is that bribing practices in the public sector may evolve in response to firm behaviors, and regional corruption is measured with error. To identify causal effects, our preferred specifications use a difference-in-differences instrumental variable methodology. We measure the manufacturing industries' sensitivity to corruption using their level of dependence to contract institutions. Controlling for regional and manufacturing industry - country fixed effects, we find that firms in more contract dependent industries located in more corrupt regions tend to have lower management quality, more centralized decision-making process and lower level of education of administrative workers. In more corrupt regions, contract dependent firms are also characterized by lower investments in $\mathrm{R} \& \mathrm{D}$ and smaller product markets. Using falsification tests, we show that contract dependent firms do not appear more affected than other firms by business barriers such as transport infrastructure, level of taxes and tax administration, or access to finance. By contrast, contract dependent firms systemically report corruption as a more severe barrier in doing business, and particularly corruption in the judicial system.
\end{abstract}

Keywords:

JEL Classification: management, institutions, corruption, firm governance.

H11, K42, L2.

\footnotetext{
*University College of London, daphne.athanasouli.09@ucl.ac.uk.

OECD, Economics Department, antoine.goujard@gmail.com.

We are grateful to Julia Korosteleva, Svetlana Makarova, Tomasz Mickiewicz, and Helena Schweiger, for their helpful suggestions and comments. We would also like to thank Elodie Douarin, Daniel Treisman, Zohal Hessami and seminar and conference participants at UCL SSEES, the RES PhD Presentation 2013 Meeting, the $6^{\text {th }}$ CESifo workshop on Political Economy, the 2012 Asian Meeting of the Econometric Society, and the BMRCQASS Conference 2012 at Brunel University, for their comments. Finally, we would like to thank Pauline Grosjean and Elena Nikolova for helping us with the data. This paper will be presented at the Royal Economic Society Conference in April 2013. The views expressed are those of the authors and do not necessarily reflect those of the OECD or its member countries.
} 


\section{Introduction}

The impact of corruption on economic performance is a key issue in development economics, central to the evaluation and design of public policies. A large existing literature investigates the determinants of corruption, and its effect on entrepreneurship. Corruption may deter entrepreneurial activity, private investment, tax revenues, waist resources and obstruct the implementation of necessary regulations. ${ }^{1}$ The World Bank estimates that 1 trillion USD, around 3.3\% World GDP, is spent on bribes every year (World Bank, 2004). However, most of the existing empirical evidence on the effect of corruption on economic performance is based on cross-country studies. This empirical strategy provides incomplete evidence of the driving mechanisms behind the impact of corruption on economic performance. Corruption may have important efficiency costs for the economy, additional to the amount of bribes paid to public officials. Therefore, the effect of corruption on firm performance, and the associated underlying mechanisms, need to be assessed when designing anticorruption and development policies (Olken and Pande, 2011, Sequeira, 2012).

This paper estimates the effect of regional corruption on firm management quality within the manufacturing sector. We construct a new data set merging measures of management quality and management practices in Central and Eastern Europe at the firm level, measures of regional corruption from household and firm surveys, and measures of sensitivity to corruption based on the contract dependence of different manufacturing industries. The precise identification of the impact of corruption on firm management quality and performance is difficult. Bribing practices can partly be a response to a dysfunctional political or economic environment. We use a difference-in-differences identification strategy, based on the different level of exposure to corruption in order to circumvent this endogeneity issue. By comparing firms that operate within the same region but have different exposure and dependence to public services, we are able to determine the precise channels through which corruption affects firm performance. We determine the firm's exposure to corruption and the institutional environment based on the level of contract dependence within their industry. We find a strong association between industry's contract dependence and manager's evaluations of corruption as a barrier in doing business. Based on this relationship, we estimate difference-in-differences instrumental-variables specifications, which display a sizable effect of corruption on management quality, management practices and firm development. The purpose of this strategy is twofold. First, it allows us to distinguish the effect of corruption on firms that is exogenous to firm behavior and is based on contract dependence from other endogenous forms of corruption, such as state capture. Second, this strategy determines the mechanisms through which exposure to corruption can impose barriers on firm performance, management practices and overall management quality

Our identification strategy delivers four main results. First, without controlling for the endogeneity of corrupt practices, we find a robust negative correlation between management quality and corruption. For the assessment of corruption we use two measures of corruption based on managers' evaluation of corruption as a barrier in doing business and the frequency of

\footnotetext{
${ }^{1}$ See among recent examples: Svensson (2003), Fisman and Svensson (2007), Bertrand et al. (2007), the reviews of Olken and Pande (2011) and Banerjee et al. (2012) and references therein.
} 
corruption, and a household measure of the frequency of corruption when interacting with public authorities. Second, we confirm the negative relationship between corruption and management quality by using our preferred difference-in-differences specification within regions. In more corrupt regions, firms with higher contract dependence have substantially worse management practices than firms with lower contract dependence. We find that for a typical establishment, with median contract dependence, an increase of regional corruption from the level observed in West Ukraine to the level observed in East Ukraine, would decrease management quality by roughly one standard-deviation. These large estimates do not appear to be driven by omitted variables or measurement error. Third, we explore specific forms of managerial organization. Contract dependent establishments located in more corrupt regions are characterized by a lower quality of management, a substantially more centralized decision-making process and lower level of education of administrative employees. In corrupt regions, contract dependent firms are also characterized by lower development prospects. This is depicted in the reduced planning of production targets, lower investments in $\mathrm{R} \& \mathrm{D}$ and smaller product markets. These findings indicate that management practices are a possible channel through which corruption affects firm performance.

We examine the deterrence of management practices as a possible transmission channel for the negative relationship between corruption and firm performance. To do this, this paper builds on three main strands of the literature. The first strand of the literature relates management practices and firm growth. Management practices are strongly linked to firm performance (Bloom and Van Reenen, 2007). Improvements in management are associated with higher annual sales growth, profitability and survival rates (Bloom and Van Reenen, 2010). Recent experimental evidence from India identifies a causal impact of management quality on firm productivity (Bloom et al., 2011). Management practices are affected by the firm's ownership structure (multinational firms and private ownership), competition and human capital (Bloom et al., 2010a,b). Bloom and Van Reenen (2007) also find that firm productivity and management quality in developing countries are significantly lower than in developed countries.

A second strand of the literature relates the institutional setting and firm organization. Institutional quality and corruption may affect firm organization. Firstly, corruption could divert firm inputs from their main economic activity. For example, Dal Bo and Rossi (2007) shows that firms distributing electricity, in more corrupt countries, employ more labor inputs to produce the same level of output. The uncertainty of a corrupt business environment, where government officials are able to capture benefits from firms, may also discourage firm investment and expansion strategies (Ades and Di Tella, 1997). In addition, the illegality of corruption and the need for secrecy could drive firms to adopt specific corporate governance structures and obstruct change and innovation (Murphy et al., 1993). Managers may seek to conceal financial information and firm operations, or limit employee involvement in the decision making process, to reduce the risk of information leakages and minimize rent seeking from public officials.

Finally, a recent literature examines the determinants of vertical integration and centralization of firms across countries. Trust is related to centralization within multinational firms Bloom et al. (2009). Acemoglu et al. (2010) and Bloom et al. (2009) find that countries with higher level of inter-individual trust and higher level of product market competition favor less 
centralized multinational firms, while countries with weak contracting institutions, severe contract enforcement problems, and sufficient financial development tend to favor more vertically integrated firms.

This paper makes three important contributions. First, we estimate how management practices depend on the quality of the business environment, based on the interactions that occur between the firms and the state. Transition countries provide an ideal experiment to study the linkages between firm behavior and corruption. Communism bequeathed weak legal and political institutions. As a result, transition countries are still characterized by various forms of corruption and ineffective institutions (Slinko et al., 2005). Based on our measures of corruption at the regional level, we find evidence supporting that each firm adopts its own best practices.

Second, we focus on regional corruption, in contrast to most of the existing literature that uses measures of corruption either at the country level or at the firm level. The use of this regional variation allows us to control for country specific heterogeneity and to estimate more precisely the effect of corruption. The institutional set-up differs significantly across the transition countries of the study. Russia underwent substantial political and institutional decentralization in the 1990s, through which its administrative regions gained some legislative and regulatory autonomy (Shleifer and Treisman, 2005), while Uzbekistan maintained a (more) centralized legislation. As argued by Shleifer and Vishny (1993), very high and heterogeneous corruption levels can occur when weak state governments do not control their local administration authorities. Therefore, we are able to exploit substantial heterogeneity in the level of corruption across countries and regions.

Finally, our difference-in-differences identification strategy isolates one of the mechanisms that is driving the relationship between corruption and firm performance. We isolate the effect of corruption on firm management quality by looking at manufacturing industries with different levels of contract dependence and exposure to the institutional environment. Theorists argue that corruption and deficient contract institutions increase the risks of moral hazard in the contracts between the firms and their suppliers, thus elevating the costs of contract dependent inputs (Acemoglu et al., 2007). Therefore we expect that corruption will disproportionately hurt firms typically dependent on contracts for their production process.

The paper is organized as follows. Section 2 discusses our assumptions about the relationship between corruption and management practices. Section 3 describes the measures of corruption and management practices and some summary statistics. Section 4 describes our difference-in-differences identification strategy. Section 5 describes our main empirical findings on the effects of corruption on management practices. Section 6 investigates the effect of corruption on specific management practices, the centralization of the firm decision process, and firm performance. Section 7 concludes.

\section{Theoretical mechanisms}

Corruption is expected to deteriorate management quality through two main channels. First, firms may adapt their structures according to regional institutions and corruption, which can lead to inefficiencies. Corruption may urge managers to engage in activities that are not directly 
productive, such as alluring public officials through unofficial payments or gifts in exchange for various services. These additional operational costs from corruption can cause a distortion of firm resources and activities away from efficiency. Firms may also choose specific forms of governance to deal with the conditions of a corrupt business environment and maintain the secrecy of any illegal interactions with the state. Isomorphic pressures can also have a strong effect on organizational strategies and culture, and institutional pressures may lead to mimetic behaviors (Frumkin and Galaskiewicz, 2004). Corruption and the expectation of unofficial payments and gifts depict an environment of favor-for-favors that can create inefficiencies in firms and influence their internal structure through management practices. Second, some firms may pay bribes to outbid competing parties in public procurement and influence government decrees to increase their market share. The resulting regulations would not impose sufficient pressure for the adoption of more competitive firm structures. This can obstruct the development of effective firm strategies, incentives for firm restructuring, and employee empowerment, resulting in lower management quality. For example, Yakovlev and Zhuravskaya (2012) show that the most corrupt regions in Russia delay or circumvent the implementation of liberalization policies. This generates considerable inefficiency, as incumbents may be favored over new entrants or innovative firms. Consequently we expect that firms operating in more corrupt regions will have lower management quality.

Turning to specific forms of management, we expect the impact of corruption to be spread on the management of the production process and human resource management. Managers would be expected to trade off aspects of operational efficiency in order to deal with public sector corruption. First, exposure to corruption could negatively impact performance monitoring. For example, in the presence of widespread corruption there may be less incentives for monitoring the production process, in order to minimize the financial information on which officials can extract bribes. We also anticipate that exposure to corruption would deter firms from setting a long-term growth strategy, due to the occurrence of additional unanticipated costs, from a dysfunctional institutional environment and increased uncertainty. Second, in more corrupt regions, firms could suffer from an inefficient allocation of human capital. For example, firms may have a larger share of administrative employees by manufacturing plant, to deal with corruption, bureaucracy and the barriers from interacting with the public sector.

The effect of corruption on firms could also be apparent in their internal decision-making process. If top managers engage in bribing public officials but want to facilitate and conceal these activities, they will tend to have a more centralized and concentrated decision-making process within the higher levels of management. Therefore a corrupt public sector could be related to management teams with more executive powers in the private sector, whereas high inter-individual trust and strong rule of law have been associated with a decentralized firm decision-making process (Bloom et al., 2009).

Our difference-in-differences identification strategy is related to the incomplete contract theory developed by Williamson $(1975,1987)$. We compare management practices in firms, within the same region, based on their industry's reliance on contract dependent inputs. This can be seen as a test of the theoretical framework of Acemoglu et al. (2007). Acemoglu et al. (2007) extend the theoretical model of Grossman and Hart (1986) and Hart and Moore (1990). Their 
model assumes that more advanced technologies require a larger number of contracts with suppliers. In more corrupt countries, the court system may be less fair and impartial and able to enforce its decisions. Therefore, in a corrupt business environment, a smaller set of inputs is contractible. Suppliers face hold-up problems when they undertake relationship specific investments for which they have to bargain ex-post with the downstream firms. The model of Acemoglu et al. (2007) predicts that contracting institutions mostly affect industries with higher contract-dependence, driving them to fewer investments in contractible and non-contractible activities, higher degrees of vertical integration, and lower technological innovation. Furthermore, even if contractual institutions are partly fixed at the national level, their model predicts that small regional changes in the number of contractible inputs can generate large changes in the productivity and investment levels.

\section{$3 \quad$ Data and preliminary evidence}

\subsection{Regional corruption in Central and Eastern Europe}

We investigate the effect of regional corruption on management practices in Central and Eastern Europe. Corruption is particularly severe in this region, based on the ICRG (International Country Risk Guide) data, the measure of controlling corruption within the political system is $2 / 5$ compared to a World average of $2.5 / 5$ in 2009 . There is a discussion in the corruption literature on whether national or regional corruption is the more appropriate unit to measure corruption (Olken and Pande, 2011). The effect of corruption on firms may occur at each of these units, and which matters the most has not been determined. We focus on regional corruption for the pragmatic reasons that we only observe management practices for ten transition countries: Belarus, Bulgaria, Kazakhstan, Lithuania, Poland, Romania, Russia, Serbia, Ukraine and Uzbekistan. In our within country estimates, all the effects of national corruption on firms are absorbed into country fixed effects. However, it is clearly of interest to investigate regional corruption, since most of the interactions between the firms and the state takes place at the regional public authorities. Furthermore above $60 \%$ of the variation in corruption occurs between regions of the same countries. It is therefore natural to expect that a large fraction of the effect of corruption on firms will arise at the regional level.

We use two surveys to evaluate regional corruption. The Business Environment and Enterprise Performance Survey (BEEPS) and the Life In Transition Survey (LITS) are two joint initiatives of the European Bank for Reconstruction and Development (EBRD) and the World Bank. The BEEPS survey examines the quality of the business environment, determined by several questions on the interaction between the private and the public sector. It provides an assessment of corruption, from firm managers in 2009. The LITS survey provides a household assessment of corruption in 2006. In both surveys, regions are defined as large subnational entities, on average 5 by country. For European countries, the regions correspond to the third level of the Nomenclature of Units for Territorial Statistics (NUTS3). For the non-European countries, the EBRD and the World Bank grouped existing national administrative divisions for sampling purposes where necessary (EBRD, 2008, 2010). 
We follow two approaches to measure the firms' assessment of regional corruption using the BEEPS 2009 survey. $^{2}$ First, to measure corruption and bribery in regional business-state interactions, we compute the regional average of the amount of bribes paid by firms. The amount of bribes paid by firms is summarized by the average regional ratio of bribes over annual sales. This ratio builds on Svensson (2003) and Reinikka and Svensson (2006). Although this measure may reflect the ability of corrupt public officials to extract rents as well as the ability of firms to grease an inefficient administration, it is a direct measure of the managers' experience of corruption. The hypothetical question is carefully worded and limited to petty corruption to encourage reliable responses: It is said that establishments are sometimes required to make gifts or informal payments to public officials to get things done with regard to customs, taxes, licenses regulations, services, etc. On average \% of annual sales for an establishment like this one. Second, we use the regional average of the managers' assessments of the frequency of corruption when dealing with the government. Managers are asked: Thinking about officials, would you say the following statement is always, usually, frequently, sometimes, seldom or never true? that firms in your line of business have to pay some irregular additional payments or gifts to "get things done" with regard to customs, taxes, licenses, regulations, services etc. The answers are coded from 1, never, to 6, always. We consider refusals and "don't know" answers as missing values. We compute the standardized value of the answers and we average the values in each region.

We measure the household assessment of regional corruption using the Life In Transition Survey (LITS) 2006. Regional corruption is computed as the average of eight questions that measure the access to public services. This measure of corruption examines the frequency of unofficial payments or gifts when interacting with public officials for services that should be normally delivered free of charge. The eight questions have the same wording: In your opinion, how often do people like you have to make unofficial payments or gifts in these situations?. The eight situations are: interacting with the road police, requesting official documents (e.g. passport, visa, birth or marriage certificate, land register, etc.), going to courts for a civil matter, receiving public education (primary or secondary), receiving public education (vocation), receiving medical treatment in the public health system, requesting unemployment benefits, and requesting other social security benefits. For each question, the respondent can answer: never, seldom, sometimes, usually, and always. These qualitative answers are given cardinal values from 1, never, to 5, always. We consider refusals and "don't know" answers as missing values. We standardize the eight household answers, and we obtain an indicator of the frequency of bribes, by computing their average that we then standardize. We evaluate regional corruption using the regional average (indicator) of the household responses.

Table 1 reports the different measures of regional corruption from the BEEPS 2009 and LITS 2006. Panel A displays the average share of firm sales paid as bribes and the managers' assessment of the frequency of corruption, while Panel B reports the household assessment of the frequency of corruption. Finally, Panel C displays the number of managers and household answers that were used to assess the extent of regional corruption. The extent of regional cor-

\footnotetext{
${ }^{2}$ We use median weights for all computations. Median weights include in the projection population the respondent establishments and the active establishments that could not be reached.
} 
ruption is based, on average, on the assessments of 93 managers and 165 households. Noticeably, the firm response rate to the questions on corrupt practices is low. The non-response rate, that includes firms refusing to answer these questions or firms reporting not to know the level of corruption, reaches $22.0 \%$ for the question on the amount of bribes and $9.4 \%$ for the question on the frequency of bribes paid. In comparison, nearly all households appear willing to assess the extent of corruption. The high non-response rate of firms may be a function of the political environment in which the firms operate. A politically repressive environment could lead firms to misreport or underreport the level of corruption in business-state transactions (Jensen et al., 2007). This could lead to biased estimates of the effect of corruption, an issue which we address in Section 4. All the measures of regional corruption appear to have substantial variation across regions. $60 \%$ to $80 \%$ of the overall variance of the measures occurs within countries. The different measures of regional corruption appear highly correlated. Table 2 Panel A displays the correlations between the three measures of corruption. The correlations drop slightly in magnitude when we consider within country measures of correlations (Panel B). The different measures of corruption within countries remain mostly correlated above 0.2. These lower correlations may be due to the lower heterogeneity of the different forms of corruption at the country level, or the larger sampling error of the regional estimates that are based on a small number of observations.

Figure 1 maps the regional variation in corruption for the 56 regions in the 10 transition countries of our sample. Panel A displays the regional average of the share of sales paid as bribes, while Panel B displays the household assessment of the frequency of corruption. Both measures of corruption appear spatially auto-correlated across state boundaries. However, national borders still appear to play a key role. Regions with higher density and capital cities overall display higher levels of corruption in the 10 transition countries.

We then test the informational content of our measures of regional corruption using two of the most widely used and established perception based measures of corruption at the country level. Figure 2 displays the average country score according to the International Country Risk Guide (ICRG) index, the Transparency International Corruption Perceptions Index (CPI), and two measures of corruption used in this paper at the firm and the household level, the share of sales paid as bribes by firms, and the household assessment of the frequency of corruption. Both the ICRG and CPI indices are specifically designed to allow for cross-country comparability. The CPI captures the perception of business people, academics, and risk analysts, while the ICRG index focuses on the perceptions of a panel of country experts. Even though perception based surveys have been widely criticized (Olken and Pande, 2011), the country rankings based on CPI, ICRG and the two measures of corruption we use from the firm and household surveys appear similar. Germany, Poland and Romania display systematically the lowest levels of corruption, while Kazakhstan, Ukraine, Uzbekistan and Russia display the highest. The 10 transition countries cover a range of economic progress and corruption is a salient feature. According to all four measures of corruption, most countries score systematically below the world average, with corruption levels three times above the levels of Germany. 


\subsection{Management practices}

We now turn to the main outcome variables of our analysis, firm management practices. Firm-level data measuring management practices come from the Management, Organization and Innovation (MOI) Survey. The EBRD and the World Bank implemented the Management, Organization and Innovation (MOI) Survey from October 2008 to November 2009, in conjunction with BEEPS 2009. The unit of observation is the establishment rather than the corporation. Establishments, which we also refer to as plants, or firms, have their own addresses, business names, and managers, but might be partly or wholly owned by other firms. The survey covers 1,355 public or privately owned manufacturing establishments with 50 to 5,000 employees. None of the establishments sampled in the MOI participated in the BEEPS surveys. The sampling frame, from which the manufacturing firms were selected, is based on the Bureau Van Dijk's Orbis database (as available in August 2008) with the exception of Kazakhstan and Uzbekistan. For the sampling frame in Kazakhstan the official list of establishments, obtained from the Agency of Statistics of the Republic of Kazakhstan, was used, and in Uzbekistan the Uniform State Register of Enterprises and Organizations, published by the State Department of Statistics of the Republic of Uzbekistan. The establishments belong to 11 manufacturing industries: food, textiles, garments, chemicals, plastics and rubber, metallic mineral products, basic metals, fabricate metal products, machinery and equipment, electronics, and other manufacturing plants. ${ }^{3}$ All regions within a country had to be covered, and the percentage of the sample in each region was required to be equal to at least half of the sample frame population in each region.

The MOI survey is primarily targeted at factory, production or operation managers, who are close to the day-to-day operations of the firm but are at the same time senior enough to provide an overview of management practices. Interviews were conducted face-to-face, in the manager's native language, by interviewers employed by the market research companies responsible for the implementation of the MOI survey in 2008 and 2009 (Bloom et al., 2012). The MOI contains two types of management quality measures: experience measures based on the structural characteristics of the plant, and perception measures, based on managers' self-assessment of management quality in their establishment. As argued by Bertrand and Mullainathan (2001), perception based measures of management quality can be problematic to use as dependent variables, as they are subject to measurement error that may be correlated with unobserved characteristics of the respondent or the establishment. We limit the risk of perception bias by focusing on managers' responses to questions based solely on the characteristics of the establishment's organization.

The experience based measures of management quality correspond to an aggregate indicator, which takes higher values when the establishment has adopted more advanced management practices, in the following four areas, as in Bloom et al. (2012): operations, monitoring, targets, and incentives. The operational indicator focuses on how the establishment handles process problems, such as machinery breakdown. The monitoring indicator covers the collection, moni-

\footnotetext{
${ }^{3}$ These 11 manufacturing industries correspond to a grouping of International Standard Industrial Classification of All Economic Activities (ISIC3.1) codes.
} 
toring, revision and use of production performance indicators. The targets indicator focuses on the time-scale of production targets, and the incentives indicator covers promotion criteria, practices for addressing poor employee performance, and rewarding production target achievement. The final measure of management quality is a standardized average of the four components. We also experimented by doing a principal component analysis of the four management scores. The correlation between our measure and the first principal component is 0.96 ( 0.28 with the second principal component). The first principal component explains $41.5 \%$ of the total variance, and the first two components $66.2 \%$. Therefore, we only report the results using the Bloom et al. measure of management quality, which they find to be significantly correlated with several indicators of firm productivity. Figures $3 \mathrm{a}$ and $3 \mathrm{~b}$ display the characteristics of this management measure. Figure 3a, the distribution of management practices appears negatively skewed, and poorly managed establishments appear to follow heterogeneous practices. Figure $3 \mathrm{~b}$ reports the average management practices for the 10 countries that appear highly correlated with the corruption measures of Figure 2. Countries are ranked in reverse order compared to their level of corruption. Management scores range from an average score of -0.55 in Uzbekistan to 0.35 in Lithuania. These large differences indicate that a number of firms in transition countries may not have implemented reforms on their management practices, and operate with an outdated organizational structure, stemming from years of central planning, and a lack of a business development strategy (Bloom et al., 2012).

We also investigate disaggregating the management scores into their component questions. However, answers to individual questions on management practices tend to be positively correlated. The correlations between the four components of management quality and the aggregate index range from 0.50 to $0.72 .{ }^{4}$ If a firm scores highly on one dimension of management, then it tends to perform well on all of them. In this respect transition countries do not appear different from non-transition countries covered by Bloom and Van Reenen (2010). This creates difficulties in identifying whether corruption has a stronger impact on specific management practices. The only exception appears to be the monitoring practices of the firms, which do not appear significantly correlated with most other management practices.

Finally, we compute an index of the de facto organizational characteristics of the plant. Specifically, we measure the decentralization of the decision process. We compute the average of six questions on the decisions of managers regarding: working hours, days of factory holidays, employing new workers, making investment decisions, introducing new products, and setting prices. In each of these dimensions, we consider the production process to be more centralized if managers state that they do not ask workers for their opinion prior to their decisions. The exact wording of the questions is: Does this establishment's top and middle management ask workers for their opinion with regard to any of the following decisions?. Managers can answer yes (0) or no (1). Therefore, higher values on our index indicate more centralized production plants.

Table 3 reports descriptive statistics for the 1,355 manufacturing establishments of the MOI survey. Panel A displays the main aggregate measure of management quality and its subcom-

\footnotetext{
${ }^{4}$ The correlations between the average quality of management practices and its components are reported in Appendix.
} 
ponents, operation, monitoring, targets and incentives. Panel B reports our measure of the centralization of the decision process and alternative measures of firm performance. Panel C displays the main characteristics of the establishments that we later use as control variables: the number of full time employees, the ownership structure, and the number of inhabitants in the locality of the establishment. Panel D reports the two measures of firm exposure to a corrupt business environment, contract dependence and product complexity that we discuss in Section 4 .

\subsection{Preliminary evidence}

In this section, we report conditional correlations between the management of the manufacturing establishments and the different measures of regional corruption, from the BEEPS and LITS surveys. We relate the quality of management practices in a manufacturing establishment to regional corruption, to various establishment characteristics, and country fixed effects:

$$
y_{i s r c}=\gamma C_{r c}+x_{i s r c} \beta+\alpha_{s c}+\varepsilon_{i s r c},
$$

where $i$ is an index for manufacturing plants, $s$ is an index for different manufacturing industries, $r$ is an index for regions, and $c$ is an index for countries. $y_{i s r c}$ is the quality of the firm's management practices as described in Section 3.2. $C_{r c}$ are our measures of corruption, e.g. the share of annual sales paid as bribes by the average establishment in region $r . \alpha_{s c}$ is a full set of countries interacted with manufacturing industries fixed effects, that control for differences in production technologies across countries and manufacturing industries. These controls take into account country specific characteristics, such as rule of law and overall institutional quality. This is particularly important, since rule of law may be correlated to corruption, facilitate contract enforcement and increase the likelihood of delegation. These fixed effects also control for the level of competition in a manufacturing industry at the national level. Since product market competition may decrease rent seeking opportunities and increase management quality (Bloom and Van Reenen, 2007), it could generate negative correlations between corruption and management practices. Finally, $x_{i s r c}$ is a row vector of control variables at the firm level. In all specifications, the standard errors are clustered at the regional level to take into account the level of variation in our corruption measures.

Table 4 reports the estimates of the descriptive specifications for different sets of control variables. We estimate two main specifications. We consider country and manufacturing industry fixed effects (Columns 1-3), and the interaction of manufacturing industries and country dummies to capture country specific characteristics (Columns 4-6). Furthermore, we use three different classifications of manufacturing industries: from 11 industries in a coarse classification (Panel A), 22 industries in the 2-digit ISIC3.1 classification (Panel B), and 59 industries in the 3-digit ISIC3.1 classification (Panel C). The most stringent specifications also control for basic firms characteristics and a set of noise controls to correct for measurement error in management practices (Columns 4-5). Basic firms characteristics include a quadratic function for the establishment's size (the number of full-time permanent employees), a dummy variable for unknown size, a series of dummy variables for the type of ownership, a series of dummy variables for the 
number of inhabitants in the locality, and a dummy variable taking value 1 if the establishment is part of a larger firm. Noise controls include age, gender and education, the day of the week, the time of day the interview was conducted, its duration, and a quadratic function for the date of the interview. The partial correlations generally display the expected negative sign. Regional corruption, measured as the frequency of bribes from firm and household surveys, appears to significantly deter good management practices. The estimated coefficients are stable across specifications. The similarity in the estimates of the different specifications implies that the basic establishment characteristics are mostly orthogonal to regional corruption. In some alternative specification (unreported), we also included additional controls that are likely to be endogenous: the interviewers' perception of the truthfulness of the information, their assessment of the respondent's knowledge about the firm, as well as controls for gender, and years the respondents have been working in their position. The point estimates for the estimate of corruption frequency on management quality were again stable.

By contrast, when we measure regional corruption using the share of sales paid as bribes, the estimates display an expected negative sign (Column 3) or are close to zero (Column 6), but they are all small in magnitude and insignificant at the $10 \%$ level. This underlines that measurement error on the amount of paid bribes may bias the effect of corruption on management practices towards zero. Taken at face value, the estimated effects suggest that a one standard-deviation increase in the frequency of corruption ( 0.43 points) is associated with a decrease of one-tenth standard deviation of management quality (0.11 points). The estimated association is substantial. It is the equivalent, in terms of management quality, of a move from the average Ukrainian establishment to the average Polish establishment.

Panel D of Table 4 confirms the robustness of the cross-sectional association between regional corruption, measured as the frequency of bribes, and the quality of management practices. We add several controls at the regional level that have been emphasized by the literature as potential determinants of management practices and firm performance. We include the share of the population aged 15 to 65 , that is out-of-the labor force or unemployed, education as a proxy for human capital (Glaeser et al., 2004), and inter-individual trust (Fukuyama, 1996, La Porta et al., 1997). We consider as population out of the labor force or unemployed the share of the population aged 15 to 65 that did not work for income during the past 12 months. We proxy education by the share of individuals between 15 and 65 years old who only completed primary education or do not hold a degree. Inter-individual trust corresponds to the answer to: Generally speaking, would you say that most people can be trusted, or that you can't be too careful in dealing with people. While regional education and individual trust appear to have the expected signs, none of them is significant and the point estimates for the effect of corruption on management practices are even slightly higher than in Panel C.

Despite this large set of control variables, Ordinary Least Squares (OLS) estimates of the impact of corruption on firm behavior are unlikely to identify $\gamma$, the parameter of interest, because $C_{r c}$ may be correlated to unobserved firm characteristics through $\varepsilon_{i s r c}$. This identification problem is difficult to circumvent for three main reasons. First, simultaneity can come from the fact that more corrupt industries may have specific unobserved characteristics related to management practices. For example, unproductive firms or badly managed firms may rely 
heavily on bribes, as a mean to improve their competitiveness, and gain access to markets. Most firms in the MOI sample are large. This suggests that regulatory and political processes are potentially captured by these powerful enterprises. By contrast, more productive or larger firms may be the targets of corrupt public officials, who attempt to extort a higher amount of bribes. The two mechanisms imply that regional corruption and firm management practices are mutually dependent. Second, the results of the specification 1 may be affected by omitted variable biases at the regional level. We control for country fixed effects and some regional characteristics, however more corrupt regions may also be poorer, have higher criminality rates and less effective enforcement capacity. In turn, poverty rates or enforcement capacity may be correlated with firm behaviors. For example, the legal and regulatory framework may deter corruption and ease the administrative burden, but it could also directly affect firm management practices. Hence, it is important to compare the effect of corruption in different manufacturing industries operating under a similar level of enforcement of anti-corruption laws. Finally, the measures of corruption may be subject to measurement error. This may lead to attenuation bias in our fixed effect specification 1. Combined, the three different forms of biases could drive OLS estimates to over or under-estimate $\gamma$, depending on which measure of management quality and corruption is used.

\section{Empirical strategy}

\subsection{Main empirical specification}

The exposure to corruption varies across industry industries and regions. We use regional measures of corruption and the different sensitivities of manufacturing industries to corruption to avoid biases due to omitted regional characteristics. More precisely, we identify manufacturing industry characteristics that affect the exposure of firms to corruption. The estimation strategy is to run regressions of the form:

$$
y_{i s r c}=\gamma \times \exp _{s} \times C_{r c}+x_{i s r c} \beta+\alpha_{s c}+\delta_{r c}+\varepsilon_{i s r c},
$$

where $i$ is an index for manufacturing plants, $s$ is an index for different manufacturing industries, $r$ is an index for regions, and $c$ is an index for countries. $y_{i s r c}$ is a firm outcome: management practices, centralization of the decision process, or firm performance. $C_{r c}$ is a measure of corruption, e.g. the share of sales paid as bribes in region $r$. $\exp _{s}$ is the exogenous exposure to corruption of manufacturing industry $s$. The coefficient of interest is $\gamma$. It captures the differential effect of regional corruption on firm outcomes. The main advantage of specification 2 compared to 1 is that it allows to control for $\delta_{r c}$ a series of regional fixed effects that capture geographical unobservable characteristics. These fixed effects control for macroeconomic instability, the level of education of the labor force, the quality of regional infrastructure, and the overall legal and institutional environment.

The final variable needed to estimate specification 2 is the manufacturing industry's exposure to regional corruption, $\exp _{s}$. The literature has identified two measures of industry dependence on corruption and institutional quality. These measures rely on the structure of manufacturing 
industry intermediate inputs to determine their dependence on contracting institutions. First, the nature of intermediate inputs determines the industry dependence on institutions (Nunn, 2007, Rauch, 1999). Some industries depend heavily on relationship-specific investments to produce a particular good, and corruption provides opportunities for private firms to deviate from the specified contractual terms. For example, computer and electronic equipment manufacturing industries rely heavily on inputs that are not openly traded on an exchange market. Therefore, they depend on specific contracts, and their enforcement by regional institutions. By contrast, manufacturing firms that rely on inputs traded on markets depend less on regional institutions. This leaves little scope for kickbacks, moral hazard, and contract enforcement. Under this assumption, regional corruption generates larger transaction costs in the more contract dependent manufacturing industries, and larger losses in management quality, as managers have to exert more effort and resources to deal with the requirements of a corrupt public sector. Second, goods with more complex production processes may be more affected by corruption and disorganization (Blanchard and Kremer, 1997). Industries that buy fewer intermediate inputs from other industries should be less dependent on courts, regulatory authorities and regional governments (Rajan and Subramanian, 2007, Levchenko, 2007). Chor (2010) demonstrates that contract dependence and product complexity capture different sources of vulnerabilities to institutions across countries.

We measure contract dependence as the share of industry inputs that are not traded on markets (Nunn, 2007). Additionally, we define product complexity as minus the Herfindahl index of input concentration (Blanchard and Kremer, 1997). Data on the actual use of inputs are typically not available for the countries of the MOI survey. Even if these data were available, their use would be prohibited, since the use of inputs depends on the overall institutional environment and regional corruption. Since the latter is precisely what we aim to investigate, this information is contaminated. In order to avoid these endogeneity issues, we use data on contract dependence from manufacturing industries in the United States (Nunn, 2007) and input-output data from the U.S. (Rajan and Zingales, 1998, di Giovanni and Levchenko, 2010). Under the assumption that US institutions do not distort the industry demand for inputs, US data allow identifying the industry composition of input demand, driven by technological characteristics, from the demand driven the institutional environment. For the construction of the measure of input concentration, we use the 1997 United States benchmark Input-Output (I-O) table at the 6 digit level, similar to the data used by Nunn (2007) to compute measures of contractdependence $^{5}$. Finally, we match the I-O industry classication to the ISIC3.1 industries, used in the MOI survey, by constructing a concordance. We use the I-O classication to NAICS 97 concordance from the U.S. Bureau of Economic Analysis (BEA) and concordance between the NAICS97, NAICS02 and ISIC3.1 from the U.S. Bureau of Labor Statistics (BLS). We use equal weights when we aggregate the I-O industries to the 4 digit ISIC3.1 classication (see data Appendix for detail).

For each 4-digit industry of the MOI survey, we have 1997 benchmark US data for inputs that

\footnotetext{
${ }^{5}$ Nunn (2007) and Rauch (1999) have a liberal and a conservative definition of goods, including goods sold on an exchange market, and goods with listed prices. Throughout the paper we use their liberal definition. However, none of the results in the paper are affected if we use the conservative definition.
} 
are either sold on an organized exchange market, have listed prices, or inputs that do not belong in either of the previous categories. Figure 4 reports the distribution of our two proxies for the dependence to regional corruption across firms. Both the measure of contract-dependence and the measure of product complexity exhibit significant variation across manufacturing industries. The MOI survey provides information only about the main product of each establishment. Although there may be some misclassification between industrial industries, this bias should be limited in the estimation, as the main product represents on average $82 \%$ of the sales, and we aggregate manufacturing industries at the 2 or 3 digit level.

\subsection{Falsification tests and graphical evidence}

Research designs produce the cleanest estimates when the treatment and control groups are randomly assigned. Unfortunately, exposure to corruption, as measured by contract dependence or product complexity, may not be randomly allocated across industries. As our specification 2 controls for regional fixed effects and country-industry fixed effects, it allows for unobserved regional characteristics that are correlated with regional corruption, and unobserved manufacturing industry characteristics that are correlated with contract dependence or product complexity. The crucial concern to rule out is the interaction between the two forms of unobserved characteristics (Almeida and Carneiro, 2012, Mian and Sufi, 2012). In order to address this concern, we investigate whether high contract dependent firms are more likely compared to low contract dependent firms to report, certain regional characteristics and regional economic conditions as significant business barriers. For example, we test if high contract dependent firms are more affected compared to low contract dependent firms by the quality of regional infrastructures. Though a definite answer to this question is difficult, we investigate the relationship between institutional dependence and managers' assessment of business barriers, within regions, using the BEEPS 2009 for the 10 transition countries of the MOI sample.

The BEEPS survey asks managers to assess various legal, economic, and political impediments to their business operations. We compare the managers' assessment of business barriers to their establishment dependence on contracts. Table 5 Panel A reports the partial correlations of our measures of contract dependence and the likelihood that a manager answers that a particular factor constitutes a severe obstacle in doing business, controlling for regional fixed effects. This specification points towards the industries that are primarily affected by some regional business barriers. Acemoglu and Johnson (2005) implement a similar strategy to verify the validity of legal origin, as an instrument for the quality of the legal system. As expected, within a given region, the managers of contract dependent firms are more prone to state that corruption is a problem for doing business (Column 1). Managers of contract dependent firms are also more likely to state that the courts are corrupt and partial, while they do not tend to report that the judicial system is slow (Columns 2 and 3). As a result, the managers' assessment of the quality of courts as a barrier to doing business is strongly predicted by our measure of dependence to contractual institutions (Column 4). Similarly, managers of contract dependent firms report being more affected by political instability and crimes (Columns 5 and 6). By contrast, there is no significant relationship between our measure of contract dependence and 
managers' assessment of corporate tax rates, tax administration, business licensing and permits, access to finance or transport infrastructure, as barriers in doing business (Panel C). Managers of contract dependent firms appear only slightly more likely to state that the education of the labor force is a problem for firm operation, though this result is only significant at the $10 \%$ significance level (Panel C, Column 6). Overall we find that contract dependence is correlated with the reporting of corruption as a business barrier, while it is mainly unrelated to other business barriers, proxying for regional institutional quality and economic conditions. We interpret this pattern as evidence that our measure of contract dependence does capture a firm sensitivity to corruption, which is largely unrelated to other possible business barriers. Therefore, we interpret the estimates of our difference-in-differences specification 2, based on contract dependence, as estimates that capture a causal effect of regional corruption on manufacturing industries.

Panels $\mathrm{B}$ and $\mathrm{E}$ of Table 5 show that the complexity of the production process, as measured by (minus) the Herfindahl index of inputs, captures different industry vulnerabilities to business barriers compared to our measure of contract dependence. In general, the estimates have the expected sign but are not statistically different from zero, at the $10 \%$ significance level. In unreported estimations, we obtain similar results, using a probit model, and alternative measures of input diversification, such as the Gini coefficient, the share of the 20 most important inputs, or a 3-digit input classification instead of a 6-digit classification. We therefore focus on the measure of contract dependence while robustness checks in the Appendix, when we use (minus) the Herfindahl index to capture the complexity of the production process, report qualitatively similar results

Figures 5 and 6 provide initial graphical evidence on the results of our identification strategy. In Figure 5, we split the industries by quintiles, based on their contract dependence. High corruption exposure industries are in the upper quintile, and low corruption exposure industries are in the lower quintile. For each region, we calculate the quality of management practices in the two groups. We report their relationship with regional corruption on Figure 5. For both groups of firms, we regress management quality on regional corruption. For high contract dependent firms, regional corruption is associated with a significant decrease in management quality. By contrast, management quality appears nearly independent of regional corruption for firms with low contract dependence. The difference of slopes between the two groups of firms is statistically significant at the $1 \%$ level.

Figure 6 provides a detailed investigation of our identifying assumption. For each region, we run a regression of our measure of management quality on the contract dependence of the firms. Each circle in Figure 6 represents a coefficient of one of these regressions, which is plotted against the household assessment of regional corruption. The size of the circle is the number of firms sampled in the MOI survey, with larger circles indicating more precise estimates. Most coefficients are negative, indicating that more contract dependent firms tend to have lower management quality. We then fit a regression of the estimated effects of contract dependence on regional corruption. The regression is weighted by the square root of the number of firms in each region. The slope of the regression line is negative and statistically significant, showing that coefficients are disproportionally negative in more corrupt regions. Furthermore, regions where a few firms are located do not appear to drive this result. Figure 6 indicates that higher 
regional corruption leads to a larger loss of management quality in more contract dependent industries.

\subsection{Impact of measurement error}

The estimates of specification 2 may be biased by two forms of measurement error. First, technological demand for firm inputs in transition countries may not be identical to the US. Second, regional corruption is imperfectly measured. Survey reports of corruption are likely to be approximate and partly based on the respondent's beliefs, since the corrupt practices are illicit and secretive. In a politically repressive environment, firms may use non-response or false response as a self-protection mechanism (Jensen et al., 2007). Firms may also respond to regional public sector corruption by avoiding to deal with government officials, and the amount of paid bribes can in this case understate the actual corruption levels (Olken and Barron, 2009, Sequeira and Djankov, 2011). In addition, the measures of regional corruption are not based on all firms or all households in the regions, as some firms and households have not been sampled, while others have not responded to the questions on corruption. Both forms of measurement errors may result in biased estimates of the effects of regional corruption on management practices.

Our US measure of contract dependence may be an imperfect proxy for technological demand for different inputs in transition countries. This concern is limited as we only focus on manufacturing industries (Rajan and Zingales, 1998), and a disaggregated classification of industries, that is likely to capture similar produced goods in different countries. However, differences in technologies across countries and regions could bias our difference-in-differences estimates. This form of measurement error may lead to underestimate or overestimate $\gamma$ in specification 2 . US-based proxies may reflect industry specific effects and US industry idiosyncrasies. The later measurement error may be correlated with some regional industry characteristics. For example, regions with lower corruption levels may have industry characteristics that are similar to the US manufacturing firms. This non-classical measurement error may lead to an overstatement of the effect of corruption (Ciccone and Papaioannou, 2007, 2010). By contrast, if US industry idiosyncrasies are orthogonal to region specific industry characteristics, then there will be an attenuation bias and underestimation of the true effect of corruption. The consistent estimation of the effect of corruption on management quality requires a measure of contract dependence that does not reflect a particular institutional environment. Our baseline approach is to instrument the interaction term between the US manufacturing industry contract dependence and regional corruption, using manufacturing dummies interacted with regional corruption. A simple rationale for these instruments is that they do not depend on the characteristics of US manufacturing industries, or on specific characteristics of the regions in which manufacturing industries operate. More precisely, we use a 4-digit manufacturing industry sensitivity to contract institutions and more aggregated industry dummies. ${ }^{6}$ The reduced form specification of the two stage least squares strategy is interesting in its own right. It estimates the differential

\footnotetext{
${ }^{6}$ Ciccone and Papaioannou (2010) examine the case in which industry fixed effects and industry measures of dependence to corruption are measured at the same level of aggregation.
} 
effect of corruption in manufacturing industry $s, \hat{\gamma}_{s}$ :

$$
y_{i s r c}=\sum_{s} \gamma_{s} \cdot C_{r c}^{*} \cdot 1_{i \in s}+x_{i s r c} \beta+\alpha_{s c}+\delta_{r c}+\zeta_{i s r c}
$$

where $C_{r c}^{*}$ is a measure of corruption in region $r$. The estimator, $\hat{\gamma}_{s}$, is consistent, when the number of regions is large. Here, we have 56 regions, the same number of observations as in most cross-country studies of industries (Ciccone and Papaioannou, 2010, Fisman and Love, 2007). We have $s$ instruments and Equation 2 is overidentified. This allows for testing the validity of our instrumental variables' strategy.

The final variable needed to estimate the system of equations 2 and 3 is a measure of regional corruption, $C_{r c}^{*}$. In the baseline specification of Ciccone and Papaioannou (2007, 2010), $C_{r c}^{*}$ is equal to $C_{r c}$. As argued in Section 2, our preferred measure is the share of annual sales, paid as bribes, from the 2009 BEEPS survey. The main advantage of this measure is the provision of a clear scale for the level of corruption. However, this corruption measure is subject to large measurement error. Therefore, we choose the household perception of corruption, from the LITS 2006, to compute our preferred instruments. The joint use of firm and household surveys has two main advantages. First, the household survey covers a less selected set of respondents, and its larger sample size may have a better representation at the regional level. Second, the use of independent reports from different surveys on corruption can lead to more consistent instrumental variable estimates if the measurement errors of the two surveys are uncorrelated (Ashenfelter and Krueger, 1994, Ammermueller and Pischke, 2009). The LITS measure of regional corruption is not directly related to firm perception or experience. Furthermore, household perceptions contain significant information about corruption (Olken, 2009). This strategy aims to overcome the benchmarking bias, caused by the fact that our measure of contract dependence is computed from US input-output data, and the measurement error on the reporting of bribes as a share of sales.

\section{$5 \quad$ Empirical results}

\subsection{Reduced form and main empirical estimates}

We begin our empirical investigation by reporting the results of the reduced form specifications 3. We examine how each of these industries performs in terms of management quality, when regional corruption increases. Table 6 displays the results of simple F-tests for the differential effects of regional corruption by manufacturing industry. We test if the sensitivity of management practices to corruption is equal across manufacturing industries. More precisely, we test $H_{0}$ : for all s, $\gamma_{s}=\gamma$ in specification 3 . The rejection of $H_{0}$ also implies that corruption has a significant effect on the management of manufacturing firms.

Table 6 reports the results of the F-tests for three industry classifications and two sets of control variables. We group manufacturing industries into industries based on the ISIC3.1 classification. Our preferred level of industry classification is the ISIC3.1 2 digit level, and we report, as robustness checks, the results of a coarser classification, and a more granular 
classification. In all specifications, the F-tests are clustered at the regional times the coarse manufacturing industry level. In all but two of the 18 specifications we estimate, we reject the null hypothesis of equal effect of corruption on management quality, at the $1 \%$ significance level. For the remaining two specifications, we reject the null hypothesis of equal effect of corruption, across manufacturing industries, at the $5 \%$ significance level. There is strong evidence that different manufacturing industries adopt different management practices in response to changes in regional corruption, and that regional corruption affects management practices.

Figure 6 displays the estimated industry specific sensitivities to corruption, as measured by the household assessment of the frequency of bribes, when dealing with public officials, from the LITS 2006. Panel A reports the estimates of industry sensitivity to corruption using a 2-digit classification on the solid line, while the vertical bars represent the $90 \%$ confidence interval. Manufacturing industries are ranked based on their sensitivity level to corruption, with more negative numbers indicating industries for which regional corruption has a higher impact on management quality. Panel B displays similar estimates for a 3-digit classification. Each number corresponds to the relative impact, of the industry exposure to regional corruption, on managerial practices, estimated from equation 3. Manufacturing industries are ranked in a consistent order. Panel A ranges from the recycling and food industries, the two industries least affected by corruption, to the manufacturing of coke, refined petroleum products and nuclear fuel, and the manufacturing of medical, precision and optical instruments, watches and clocks, which are the two industries most affected by corruption. Similarly, Panel B, manufacturing of recycling and transport equipment appears the least affected by regional corruption, while management quality in the industries of refined petroleum products, optical instruments, and photographic equipment, appears extremely sensitive to regional corruption. This provides evidence that the identification strategy we pursue in this paper does not rely on a particular statistical specification.

Table 7 uses the differential effects of corruption across manufacturing industries to implement our difference-in-differences identification strategy. We assume that industries more dependent to contracts will be more affected by regional corruption, and that this dependence is fully captured by our US measure of dependence to institutions. We report the estimated interactions between the US industry dependence to institutions and the three different measures of regional corruption, according to the specification 2. Column 1 starts with the managers' assessment of corruption frequency in the interaction of their firms with public officials. Columns 2 and 3 include the household assessment of the frequency of corruption and the share of annual sales paid in bribes, as reported by managers. Columns 3 to 6 report the estimates of the same interaction terms but control for a set of interview, interviewer and firm characteristics. Panels $\mathrm{A}$ to $\mathrm{C}$ display the estimates using a coarse industry classification, and the 2- and 3-digits ISIC3.1 classifications, respectively. In all specifications, the estimated effect of corruption on average management practices is more negative for firms more dependent to contractual institutions. The coefficients here can be interpreted as the effect of regional corruption for those firms whose dependence to contracts equals 1 . As the average contract dependence is $89 \%$, the estimates are naturally larger than those of the simple OLS specifications reported in Table 4. Evaluated at the mean value of contract dependence, our estimates suggest that an increase 
of one standard-deviation in the frequency of regional corruption translates into approximately 0.6 standard-deviation decrease in management quality $(-0.43 \times 0.89 \times 1.50$, Panel B, Column 5). The effect of regional corruption measured by the share of sales paid as bribes is slightly smaller. A one standard-deviation increase in this measure of corruption is associated with a decrease of management quality by 0.4 standard-deviation $(0.93 \times 0.89 \times 0.47$, Panel B, Column 6). Compared to our descriptive specifications, our difference-in-differences specification leads to a larger estimated effect of corruption on management practices. For example, an increase of one standard-deviation of household assessment of corruption was associated with a decrease in management quality by around $1 / 10$ standard-deviation $(0.43 \times 0.25$, Table 4 , Panel D, Column $5)$.

Remarkably, the inclusion of extra controls only translates into very minor shifts in the coefficients of our corruption variables (Table 4, Panels A to C). Since our data is non-experimental, the possibility of industry shocks being correlated with contract dependence is a source of concern. However, we find that accounting flexibly for most industry-country shocks (i.e. shocks that affect firms differently at the most detailed industry classification) seems to have a negligible effect on our estimates. This suggests that contract dependence is in practice a source of variation, which is separate from other industry specific shocks. This fact, and the evidence presented above that contract dependent firms do not tend to over report other aspects of the industry environment as business barriers, reinforces our belief that we are estimating the causal effect of corruption on management practices.

Table 8 reports the estimates of our difference-in-differences specification correcting for the benchmarking bias, from the use of US industry dependence to contracts. In this instrumental variable specification, the point estimates are all negative, statistically significant, and of similar magnitude to the estimates reported in Table 7 that did not correct for the US benchmarking bias. It is important to estimate this specification because if manufacturing industries, in low corruption regions share more similarities with US manufacturing industries compared to manufacturing industries in high corruption regions, the previous OLS estimates could be upward biased. Our instruments appear relevant and valid. In all specifications, the instruments exhibit a strong correlation with the endogenous regressor. The First-stage F-statistics are above 15 and the Kleibergen-Paap tests reject the null hypothesis of weak instruments at the $1 \%$ level. Therefore weak instrument biases are unlikely to be a concern (Stock et al., 2002). Furthermore, we fail to reject the null hypothesis of the Hansen-test with large p-values, above 0.4. There is no evidence that our instruments are invalid or that there is strong heterogeneity in the effect of corruption across manufacturing industries (Angrist and Pischke, 2008). This approach yields stronger evidence that regional corruption tends to deteriorate management quality in manufacturing industries. Even if regional corruption may be measured with some error, we find strong empirical evidence that it matters for management practices.

Table 9, panel A presents our preferred empirical estimates that correct for the measurement error on our preferred measure of corruption, the average share of sales paid as bribes. More precisely, we instrument the interaction between (US measures of) dependence to corruption, and the average share of sales paid as bribes in the region, using industry dummies interacted with the household perception of regional corruption. Therefore, the specification 
controls for both the benchmarking bias, stemming from using US manufacturing industry dependence to institutions as a proxy for industry specific characteristics, and the measurement error on the share of sales paid as bribes. All the point estimates of the interaction term are nearly five times larger than in Table 8 that did not account for measurement error on regional corruption. The standard-errors are also larger. This indicates that the estimates of a simple difference-in-differences specification are likely to suffer from attenuation bias. The estimates are stable across specifications between -1.80 and -2.60 . To better evaluate the magnitude of the estimates, we compare the industry at the first quartile of dependence to corruption (low dependence, 0.88 ) to a typical industry at the third quartile of dependence (0.97). The average estimate of corruption of -2.5 predicts that the management quality of a more contract dependent industry would decrease by 0.5 points more than the management quality of a less dependent industry, if regional corruption increases from the level of North to West Ukraine. This represents a large differential from the median Ukrainian firm in terms of management quality to the upper quartile firm. In comparison with other factors that may affect management quality, the effect of corruption is substantial and plausible. In the UK context, Bloom et al. (2010a) find quasi-experimental evidence that competition affects management practices. They estimate that one additional hospital increases management quality by a one-third standard deviation. The standard-deviation of their measure of hospital competition is 10. Thus, for an average firm in terms of contract dependence, a decrease of one standard-deviation of the share of sales paid as bribes would have a roughly similar impact to an increase of one standard deviation in hospital competition ( $0.93 \times 3.00 \times 0.85$, and $10 \times 0.33$, respectively).

Panel B explores the robustness of our estimates to some additional changes in our differencein-differences specifications. At the national level, corruption correlates highly with increased economic development (La Porta et al., 1999, Ades and Di Tella, 1999, Treisman, 2000, 2003). If institutionally dependent industries are also more dependent to the level of education in the workforce, and if regional corruption is correlated with education, our estimates could be biased. Therefore we add three interaction terms between our US measure of dependence to contractual institutions and regional education, inter-individual trust, and the share of the population aged 15 to 65 , that is out of the labor force or unemployed. The point estimates and standard errors of these specifications, that include additional controls, are very similar to those reported in Panel A. To further confirm that our results are not driven by product market competition, we estimated regressions controlling for product market competition. We used the managers' self-reported measure of the number of their competitors coded as five dummy variables for unknown number, no competitor, one, two to five, and more than five competitor firms. The answers represent $6.9,3.9,3.5,30.2$, and $55.5 \%$ of the sample, respectively. The results led to exactly the same conclusions as those presented here, and are therefore omitted. A likely reason that this modification did not produce significant changes to the results is that the manufacturing industry-country fixed effects capture most of the variation in product market competition.

Our empirical findings are strongly in line with the theoretical model of Acemoglu et al. (2007) that predicts that contract-dependent firms will have lower productivity, and undertake less investment, in regions with ineffective contract legislation and enforcement. This issue may be particularly strong in transition countries where the markets of intermediate goods are thin 
(Blanchard and Kremer, 1997). In the absence of alternative suppliers, firms may not be able to avoid the adverse effects of corruption on the enforcement of the contracts. Indeed, alternatives to formal contracts such as informal contracts and reputation games would require downstream firms to have many potential input suppliers. More generally, our estimates of the impact of corruption on management practices corroborate the findings of Sequeira and Djankov (2011), who find that corruption significantly affects the production choices of firms. In the context of bribery payments at African ports, they find that firms are willing to use alternative road trips and pay higher (real) trucking costs to avoid higher bribes.

\subsection{Robustness check and heterogeneity of the effect}

One potential problem with the previous analysis is that our measures of regional corruption are affected by sampling errors. When we work on the full sample, the 2SLS estimate is much larger than the OLS estimate (-0.464 and -3.014) even though the difference between the two estimates is not significant. This result may be due to measurement error on the usual share of sales paid as bribes, if the regional share of sales paid as bribes is biased by the small number of firms interviewed in the BEEPS survey. Classical measurement error would result in an attenuation bias on the OLS estimator. Assuming that the variance in the error affecting our measurement of regional corruption decreases with the number of firms interviewed in the BEEPS survey, the bias should decrease with the number of firms observed in the region. If this interpretation is correct, the difference between the OLS and the 2SLS estimates should also decrease when focusing on regions in which more firms were interviewed for the BEEPS survey.

Table 10 provides a comparison of OLS and 2SLS estimates using the same instruments as in Table 9 (i.e., household assessment of regional corruption interacted with manufacturing industry dummy variables), but restricts the sample to regions with at least 19 and 49 firms that were interviewed during the BEEPS survey. However, the OLS and 2SLS estimates remain nearly unchanged when we restrict the sample to these regions (even though the 2SLS estimator becomes more imprecise as the number of observations becomes smaller). Therefore, our estimates do not appear driven by regions where our measure of corruption is based on a small number of respondents. We further confirm this result by investigating the sensitivity of our estimates to the inclusion of specific countries. We jackknife the sample of countries excluding a country at a time and re-estimate our preferred difference-in-differences specification using OLS and 2SLS as in Tables 9 and 10 (Columns 1 and 2). The point estimates are always negative and highly statistically significant for OLS and 2SLS (Figure 8, Panels A and B). However, the magnitude of the point estimates is sensitive to the inclusion of two of the survey countries.

Specifically suppressing Uzbekistan makes the magnitude of the estimates significantly larger for both OLS and 2SLS, while suppressing Romania reduces partly the estimated effect through 2SLS. We interpret this pattern as evidence that our estimates are not driven by some country specific factors.

Table 11 investigates the heterogeneity of the effect of corruption on management quality. Bloom et al. (2009) and Bloom et al. (2012) have argued that foreign owned establishments may be less affected by regional factors and contribute to spread the management practices of their 
headquarters. If this relationship holds, we would expect the coefficient of our interaction term between contract dependence and regional corruption to be closer to zero for establishments that belong to multinational companies. Indeed foreign owned establishments are on average better managed than domestic companies. However, the management of foreign owned companies appears equally affected by regional corruption as the one of domestic firms. Similarly, we do not find significant differences in the effect of corruption on management quality between government owned and other firms, and between large (above 250 full-time employees) and smaller firms. The burden of corruption appears equally spread across firms.

\section{Detailed management practices, centralization and firm per- formance}

In this section, we investigate management practices in detail: the monitoring of the production process, the presence of medium to long-run targets, the presence of sufficient incentives in the human resources policy, and the efficiency of the production process in the establishment. The different forms of management practices are not independent. For example, human resource policies are related to closer output monitoring, and to the frequency and number of production performance indicators. We also relate regional corruption to the establishment's decision process. Finally, although our focus is on the impact of corruption on management quality, we investigate the effect of corruption on more direct measures of firm performance.

\subsection{Detailed management practices}

Table 12 reports the estimates for the aggregate index of monitoring in the production process. This aggregate index takes into account the number of performance indicators monitored in each establishment, and their review frequency by top and middle managers. Panel A reports OLS estimates of the descriptive specification 1, while Panel B reports OLS estimates of the difference-in-differences specification 2, and Panel C reports the instrumental variable estimates of specification 2 that control for the US benchmarking bias. We focus on the household perceptions of the frequency of bribes. There is a negative correlation between regional corruption and monitoring in the production process (Column 1, Panel A). This negative relationship is also observed between, contract dependence and monitoring. More contract dependent firms, in more corrupt regions, appear to have a significantly lower level of monitoring in the production process (Column 1, Panels B and C).

A substantial lack of formal maintenance procedures, methods of quality control and inventory may be linked to a weak development strategy and ability to set targets. Column 2 of Table 12 investigates the relationship between corruption and the setting of production targets. We examine whether the managers of the establishment are setting a timescale for the production targets of their main product. This timescale includes short-term (less than one year), or short and long-term (more than three years) production targets that are set together or independently. Firm exposure to corruption appears associated with the absence of a timescale of production targets for the main product. This finding could be linked to the 
negative impact of corruption on the monitoring quality, the review and coverage of monitoring indicators, which are a valuable tool for the setting of long-term targets. Firms operating in a corrupt environment may have an incentive to avoid monitoring in the production process, since the availability of this information could increase the risk of being approached for higher bribes by public officials. At the same time, firms with limited monitoring and low quality of data systems measuring production performance indicators, and general outputs and inputs, could have a higher likelihood for undetected theft (Bloom et al., 2011).

We now turn to human resource management. Columns 3-6 of Table 12 examine the relationship between corruption, a general index of worker incentives, the turnover of the workforce, and the level of education of production workers and administrative employees (including managers). The general index of worker incentives captures the distribution of rewards when production targets are met (no rewards, only top and middle management is rewarded, all staff is rewarded), the establishment's main policy for employees that do not meet expectations (rarely or never moved from their position, not removed for at least a year before action is taken, rapidly moved and retrained and dismissed if not improved), and the rewards for top-performing employees. Column 3, corruption appears related to the permanency of a position and an overall lack of meritocratic employment policy. However, the point estimates are not statistically significant at the $10 \%$ level when we consider the difference-in-differences specifications of Panels B and C.

We then investigate the components of human resource management to detect which specific human resource policies are the most affected by corruption. Column 4 investigates the relationship between workforce turnover (measured as the share of employees that quitted the establishment over the last administrative year) and corruption. Consistent with a lack of incentives and rewards, contract dependent firms have higher workforce turnover in more corrupt regions (Column 4, Panels B and C). This could mean that the effect from the lack of rewards for well performing employees dominates the effect from the lack of sanctions for employees, who do not meet managers' expectations. Columns 5 and 6 provide additional support for this interpretation. They examine the relationship between corruption and the human capital in the firm, measured as the share of employees with a college degree. More contract dependent firms have a lower educated workforce in more corrupt regions. In particular, the share of administrative employees, including managers with a college degree, is significantly lower for contract dependent firms in more corrupt regions (Column 6). The results are in line with the negative association between corruption and the quality of human resource policies in the public sector. The adoption of incentive policies and closer monitoring may deter corrupt practices by public officials (Olken and Pande, 2011).

Table 13 Column 1 turns to another dimension of management practices, process management. We find that there is a negative but insignificant relation between exposure to corruption and process management. This may be due to the small variation in the manager's answers. Specifically, process management corresponds to the course of action taken in the occurrence of process problems. In this question, a large majority of managers $(97 \%)$ replies that when process problems occur action is taken and prevention measures are implemented. Unfortunately, the question does not include other aspects of process management, for example the time required to process the problem or the occurrence of delays, which could offer a better insight into the 
effects of a corrupt environment.

\subsection{Centralization}

We further investigate the internal policy underlying the implementation process within the firm. We determine centralization, as a measure of hierarchy and decision-making, when the activities of the firm and the decision-making process are accumulated on the group of managers, and not dispersed across the production employees. Table 13 Column 2, we observe that, in contract dependent firms, corruption leads to a higher concentration of the decision-making process on the group of managers compared to less contract dependent firms. The magnitude of the association between the centralization of the decision process and regional corruption is economically sizable. For a firm with median contract dependence, a one standard-deviation increase in regional corruption would be associated with a 0.4 standard-deviation increase in the centralization of the decision process $(0.43 \times 0.93 \times 0.26 / 0.26=0.40$, Column 2, Panel C). This confirms that, in environments of widespread corruption, more conservative and centralized structures may persist, and a delegation of responsibilities could be limited to a closed network, for example family members (Bloom and Van Reenen, 2010).

\subsection{Firm performance}

Table 13 Columns 3 to 6 investigate the direct impact of corruption on firm performance. We find that corruption tends to lower innovation, as measured by two dummy variables, the introduction of a new product or service over the last 3 years, and the likelihood to have undertaken some R\&D investment over the last fiscal year. More contract dependent firms appear to have lower levels of innovation and to undertake less R\&D investments in more corrupt regions (Columns 3 and 4, and Panels B and C, respectively). This result is in line with the theoretical model of Acemoglu et al. (2007) that predicts that in regions with greater corruption and contract incompleteness, firms should adopt less advanced technologies, and that this effect should be relatively stronger for more contract dependent industries. As described by Acemoglu et al. (2007) contracting institutions can then generate endogenous comparative advantage differences across regions. Consistent with this framework, more contract dependent firms, located in more corrupt regions, tend to have relatively smaller markets. Their managers report that their main product is sold mostly in the same municipality that the establishment is located rather than on a national or international market (Column 5). The exact wording of the question is: In fiscal year 2009, which of the following was the main market in which this establishment sold its main product? Managers can answer: Local (main product sold mostly in same municipality where the establishment is located), National (main product sold mostly across the country where the establishment is located), or International (main product sold mostly to nations outside the country where the establishment is located). On average, $21.3 \%$ of the managers state that the establishment's main market is local, $54.2 \%$ state that it is national, and $23.4 \%$ state that it is international. This effect appears mainly driven by a lack of competitiveness of contract dependent firms on export markets (Column 6). The magnitude of the effect is economically sizable. When the household perceptions of the frequency of bribes 
increase by one standard-deviation (0.43), the estimate of Column 6 Panel C predicts that a firm at the last decile of contract dependence (0.98) would become by 11 percentage points less likely to mainly export its products to foreign markets compared to a firm at the first decile of contract dependence (0.68). As only $23.4 \%$ of the establishments are exporting their main product, corruption substantially shapes the manufacturing structure of regional exports. The two later findings confirm the results observed on international trade patterns. Nunn (2007) and Chor (2010) find that countries with better contract enforcement export relatively more in industries that require relationship-specific investments.

\section{Conclusion}

In this paper, we show that corruption affects the adoption of firm management practices. We find that more contract dependent firms, operating under a corrupt business environment, adopt less efficient management practices. For a typical establishment, with median contract dependence, an increase of regional corruption from the level observed in West Ukraine to the level observed in East Ukraine, would decrease management quality by roughly one standarddeviation. This effect is large, albeit imprecisely estimated. Furthermore, we believe that, if anything, we are undercounting the effect of corruption on management practices. In general, we would expect state level corruption to be a particularly important driver of firm behaviors. Our study focuses, however, only on regional corruption, an important if only partial measure of corruption.

We have argued that our findings are not consistent with the existence of omitted factors correlated with industry contract dependence. Consistent with contract dependence identifying corruption specific vulnerabilities, more contract dependent firms do not appear more likely to state that other aspects of the business environment represent significant obstacles. Hence comparing firms of the same region that are differently affected by corruption should be an effective way of dealing with the possible endogeneity of corrupt practices. As an alternative to our difference-in-differences specification estimated by OLS, we also present 2SLS estimates that control for measurement error on our measures of corruption and contract dependence. The 2SLS estimates are larger than our OLS estimates.

The actual effects of corruption appear to be spread across management practices and to affect the internal structure of the firm. In more corrupt regions, more contract dependent firms appear less well monitored, less likely to fix production targets, substantially more centralized than less contract dependent firms, and with lower level education among administrative employees. Corruption has also a clear effect of firm development and performance. Regional corruption is associated with lower levels of innovation and R\&D investment, and lower export prospects for contract dependent firms.

A drawback of our investigation is the cross-sectional nature of our data since management quality is only available for a single year. Future work could use several waves of management measures to investigate the effects of institutional changes on firm management practices. 


\section{References}

Acemoglu, D., P. Aghion, R. Griffith, And F. Zilibotti (2010): "Vertical Integration and Technology: Theory and Evidence," Journal of the European Economic Association, 8, 989-1033.

Acemoglu, D., P. Antràs, and E. Helpman (2007): "Contracts and Technology Adoption," American Economic Review, 97, 916-943.

Acemoglu, D. And S. Johnson (2005): "Unbundling Institutions," Journal of Political Economy, 113, 949-995.

Ades, A. And R. Di Tella (1997): "National Champions and Corruption: Some Unpleasant Interventionist Arithmetic," Economic Journal, 107, 1023-42.

(1999): "Rents, Competition, and Corruption," American Economic Review, 89, 982993.

Almeida, R. And P. CARneiro (2012): "Enforcement of Labor Regulation and Informality," American Economic Journal: Applied Economics, 4, 64-89.

Ammermueller, A. And J.-S. PIschke (2009): "Peer Effects in European Primary Schools: Evidence from the Progress in International Reading Literacy Study," Journal of Labor Economics, 27, 315-348.

Angrist, J. And J. Pischke (2008): Mostly harmless econometrics: An empiricist's companion, Princeton University Press.

Ashenfelter, O. And A. B. Krueger (1994): "Estimates of the Economic Returns to Schooling from a New Sample of Twins," American Economic Review, 84, 1157-73.

Banerjee, A., S. Mullainathan, And R. Hanna (2012): "Corruption," Working Paper 17968, National Bureau of Economic Research.

Bertrand, M., S. Djankov, R. Hanna, and S. Mullainathan (2007): "Obtaining a Driver's License in India: An Experimental Approach to Studying Corruption," The Quarterly Journal of Economics, 122, 1639-1676.

Bertrand, M. and S. Mullainathan (2001): "Do People Mean What They Say? Implications for Subjective Survey Data," American Economic Review, 91, 67-72.

Blanchard, O. And M. Kremer (1997): "Disorganization," The Quarterly Journal of Economics, 112, 1091-1126.

Bloom, N., B. Eifert, A. Mahajan, D. McKenzie, and J. Roberts (2011): "Does Management Matter? Evidence from India," NBER Working Papers 16658, National Bureau of Economic Research, Inc. 
Bloom, N., C. Propper, S. Seiler, and J. V. Reenen (2010a): "The Impact of Competition on Management Quality: Evidence from Public Hospitals," NBER Working Papers 16032, National Bureau of Economic Research, Inc.

Bloom, N., R. Sadun, and J. V. Reenen (2009): "The organization of firms across countries," NBER Working Papers 15129, National Bureau of Economic Research, Inc.

(2010b): "Does Product Market Competition Lead Firms to Decentralize?" American Economic Review, 100, 434-38.

Bloom, N., H. Schweiger, And J. V. Reenen (2012): "The Land that Lean Manufacturing Forgot? Management Practices in Transition Countries," Economics of Transition, 20, 593635.

Bloom, N. And J. Van Reenen (2007): "Measuring and Explaining Management Practices Across Firms and Countries," The Quarterly Journal of Economics, 122, 1351-1408.

(2010): "Why do management practices differ across firms and countries?" The Journal of Economic Perspectives, 24, 203-224.

Chor, D. (2010): "Unpacking sources of comparative advantage: A quantitative approach," Journal of International Economics, 82, 152-167.

Ciccone, A. And E. Papaionnnou (2007): "Red Tape and Delayed Entry," Journal of the European Economic Association, 5, 444-458.

(2010): "Estimating Cross-Industry Cross-Country Models Using Benchmark Industry Characteristics," CEPR Discussion Papers 8056, C.E.P.R. Discussion Papers.

Dal Bo, E. And M. A. Rossi (2007): "Corruption and inefficiency: Theory and evidence from electric utilities," Journal of Public Economics, 91, 939-962.

Di Giovanni, J. And A. A. Levchenko (2010): "Putting the Parts Together: Trade, Vertical Linkages, and Business Cycle Comovement," American Economic Journal: Macroeconomics, $2,95-124$.

EBRD (2008): "Management and Organisation Survey, Sampling methodology," mimeo, European Bank for Reconstruction and Development (EBRD).

(2010): "The Business Environment and Enterprise Performance Survey (BEEPS) 20082009, A Report on methodology and observations," mimeo, European Bank for Reconstruction and Development (EBRD).

Fisman, R. And I. Love (2007): "Financial Dependence and Growth Revisited," Journal of the European Economic Association, 5, 470-479.

Fisman, R. AND J. Svensson (2007): "Are corruption and taxation really harmful to growth? Firm level evidence," Journal of Development Economics, 83, 63-75. 
Frumkin, P. and J. Galaskiewicz (2004): "Institutional Isomorphism and Public Sector Organizations," Journal of Public Administration Research and Theory, 14, 283-307.

Fukuyama, F. (1996): Trust: The Social Virtues and The Creation of Prosperity, Free Press New York.

Glaeser, E. L., R. L. Porta, F. L. De Silanes, and A. Shleifer (2004): "Do Institutions Cause Growth?" Journal of Economic Growth, 9, 271-303.

Grossman, S. J. And O. D. Hart (1986): "The Costs and Benefits of Ownership: A Theory of Vertical and Lateral Integration," Journal of Political Economy, 94, 691-719.

Hart, O. And J. Moore (1990): "Property Rights and the Nature of the Firm," Journal of Political Economy, 98, 1119-58.

Jensen, N. M., Q. Li, And A. Rahman (2007): "Heard melodies are sweet, but those unheard are sweeter : understanding corruption using cross-national firm-level surveys," Policy Research Working Paper Series 4413, The World Bank.

La Porta, R., F. Lopez-De-Silanes, A. Shleifer, and R. Vishny (1997): "Trust in Large Organizations," American Economic Review, 87, 333-38.

La Porta, R., F. Lopez-de Silanes, A. Shleifer, and R. Vishny (1999): "The Quality of Government," Journal of Law, Economics and Organization, 15, 222-79.

Levchenko, A. A. (2007): "Institutional Quality and International Trade," Review of Economic Studies, 74, 791-819.

Mian, A. And A. Sufi (2012): "The Effects of Fiscal Stimulus: Evidence from the 2009 Cash for Clunkers Program," The Quarterly Journal of Economics, 127, 1107-1142.

Murphy, K. M., A. Shleifer, And R. W. Vishny (1993): "Why Is Rent-Seeking So Costly to Growth?" American Economic Review, 83, 409-14.

Nunn, N. (2007): "Relationship-Specificity, Incomplete Contracts, and the Pattern of Trade," The Quarterly Journal of Economics, 122, 569-600.

Olken, B. (2009): "Corruption perceptions vs. corruption reality," Journal of Public Economics, 93, 950-964.

Olken, B. A. And P. Barron (2009): "The Simple Economics of Extortion: Evidence from Trucking in Aceh," Journal of Political Economy, 117, 417-452.

Olken, B. A. And R. Pande (2011): "Corruption in Developing Countries," Working Paper 17398, National Bureau of Economic Research.

Rajan, R. And A. Subramanian (2007): "Does Aid Affect Governance?" American Economic Review, 97, 322-327. 
Rajan, R. G. And L. Zingales (1998): "Financial Dependence and Growth," American Economic Review, 88, 559-86.

RAUCH, J. E. (1999): "Networks versus markets in international trade," Journal of International Economics, 48, 7-35.

Reinikka, R. And J. Svensson (2006): "Using Micro-Surveys to Measure and Explain Corruption," World Development, 34, 359-370.

Sequeira, S. (2012): New Advances in Experimental Research on Corruption, Emerald Publishing, chap. Advances in Measuring Corruption in the Field.

Sequeira, S. And S. DJankov (2011): "Corruption and firm behaviour: evidence from African ports," Working paper, London School of Economics.

Shleifer, A. And D. Treisman (2005): "A Normal Country: Russia after Communism," Journal of Economic Perspectives, 19, 151-174.

Shleifer, A. And R. W. Vishny (1993): "Corruption," The Quarterly Journal of Economics, 108, 599-617.

Slinko, I., E. Zhuravskaya, And E. Yakovlev (2005): "Laws for Sale: Evidence from Russia," American Law and Economics Review, 7, 284-318.

Stock, J. H., J. H. Wright, And M. Yogo (2002): "A Survey of Weak Instruments and Weak Identification in Generalized Method of Moments," Journal of Business \& Economic Statistics, 20, 518-29.

Svensson, J. (2003): "Who Must Pay Bribes And How Much? Evidence From A Cross Section Of Firms," The Quarterly Journal of Economics, 118, 207-230.

Treisman, D. (2000): "The causes of corruption: a cross-national study," Journal of Public Economics, 76, 399-458.

- (2003): "Postcommunist corruption," Political Economy of Transition and Development: Institutions, Policies and Politics, 201-26.

Williamson, O. (1975): Markets and hierarchies, analysis and antitrust implications: a study in the economics of internal organization, A study in the economics of internal organization, Free Press.

- (1987): The economic institutions of capitalism: firms, markets, relational contracting, Free Press.

World BANK (2004): "The Costs of Corruption," World bank news \& broadcast, april 8th 2004, World Bank.

Yakovlev, E. And E. Zhuravskaya (2012): "The Unequal Enforcement of Liberalization: Evidence from Russia's Reform of Business Regulation," Journal of European Economic Association. 


\section{Data appendix}

\section{Detailed corruption questions (BEEPS)}

We use the BEEPS 2009 survey to compute regional corruption. We use information for all firms in manufacturing sectors and services. In addition to the 11 manufacturing sectors surveyed in the MOI survey (food, textiles, garments, chemicals, plastics \& rubber, metallic mineral products, basic metals, fabricate metal products, machinery and equipment, electronics, and other manufacturing plants), the BEEPS survey includes information on services (wholesale and retail trades, services of motor vehicles - section $\mathrm{G}$-, and hotel and restaurants - section $\mathrm{H}$ -), computer and related activities (IT), the construction sector - section F -, and the sector of transport, storage and communications - section I -. By contrast, the BEEPS survey does not contain information on real estate and renting activities, financial intermediation, and public and utilities sectors. We use median weights for all computations involving the 2009 survey $^{7}$.

The share of sales paid as bribes comes from three questions in the BEEPS survey 2009. The main question is the following: It is said that establishments are sometimes required to make gifts or informal payments to public officials to "get things done" with regard to customs, taxes, licenses, regulations, services etc. On average, what percent of total annual sales, or estimated total annual value, do establishments like this one pay in informal payments or gifts to public officials for this purpose (j7a). If the respondent reports the total amount of bribes rather than the share of sales paid as bribes ( $\mathrm{j} 7 \mathrm{~b}$ ), the total amount of bribes is divided by the total sales of the last complete fiscal year (question d2). Refusals and "don't know" answers have been coded as missing.

The barrier to growth measure of corruption comes from the question: As I list some factors that can affect the current operations of a business, please look at this card and tell me if you think that each factor is no obstacle, a minor obstacle, a moderate obstacle, a major obstacle, or a very severe obstacle to the current operations of this establishment (corruption question j30f). Answers are recoded from 0 , no obstacle, to 4, very severe obstacle. Refusals and "don't know" answers are coded as missing.

\section{Variance decomposition formula}

In Table 1, we decompose the total variance in these regional averages into the parts of the variance within and between countries using the relationship:

$$
\frac{1}{R} \sum_{c} \sum_{r}\left(x_{c r}-x_{. .}\right)^{2}=\frac{1}{R} \sum_{c} \sum_{r}\left(x_{c r}-x_{c .}\right)^{2}+\frac{1}{R} \sum_{c} R_{c}\left(x_{c .}-x_{. .}\right)^{2}
$$

where $r$ is an index for regions, and $c$ is an index for countries. $x_{c r}$ is a particular measure of corruption averaged at the regional level. $x_{. .}, x_{c}$. are unweighted overall and country averages. There are $R_{c}$ regions in country $c . R$ is the total number of regions across all countries in our sample.

\footnotetext{
${ }^{7}$ Median weights correspond to an adjustment of the stratum of the survey. Median weights include in the projection population the answering establishments and the active establishments that could not be reached.
} 


\section{Matching industry classifications}

We match the US I-O industry classication to the ISIC3.1 industries used in the MOI survey, by constructing a concordance using the I-O classication to NAICS 97 concordance from the U.S. Bureau of Economic Analysis (BEA) and concordance between the NAICS97, NAICS02 and ISIC3.1 from the U.S. Bureau of Labor Statistics (BLS).

More precisely, we use the following files:

- http://www.bea.gov/national/zip/ndn0306.zip (NAICS-IO.xls and NAICSUseDetail.txt);

- http://www.economics.harvard.edu/faculty/nunn/files/contract_intensity_IO_1997.xls;

- http://www.census.gov/eos/www/naics/concordances/1997_NAICS_to_2002_NAICS.xls;

- http://www.census.gov/eos/www/naics/concordances/2002_NAICS_to_ISIC_3.1.xls.

We map the I-O 6-digit classification to the NAIC97, then to the NAICS2002, and to the ISIC3.1 classifications. There are some ISIC3.1 industries that overlap several I-O codes, and we use equal weights when we aggregate the I-O industries to the 4 digit ISIC3.1 classication. In the end, for each 4-digit ISIC3.1 industry of the MOI survey, we have 1997 benchmark U.S. data on the concentration of inputs and the fraction of inputs that is either sold on an organized exchange market, have listed prices, or inputs that do not belong in either of the previous categories. 
Figure 1. Map of regional corruption

Figure 1.a. Firm share of sales paid as bribes (BEEPS 2009)

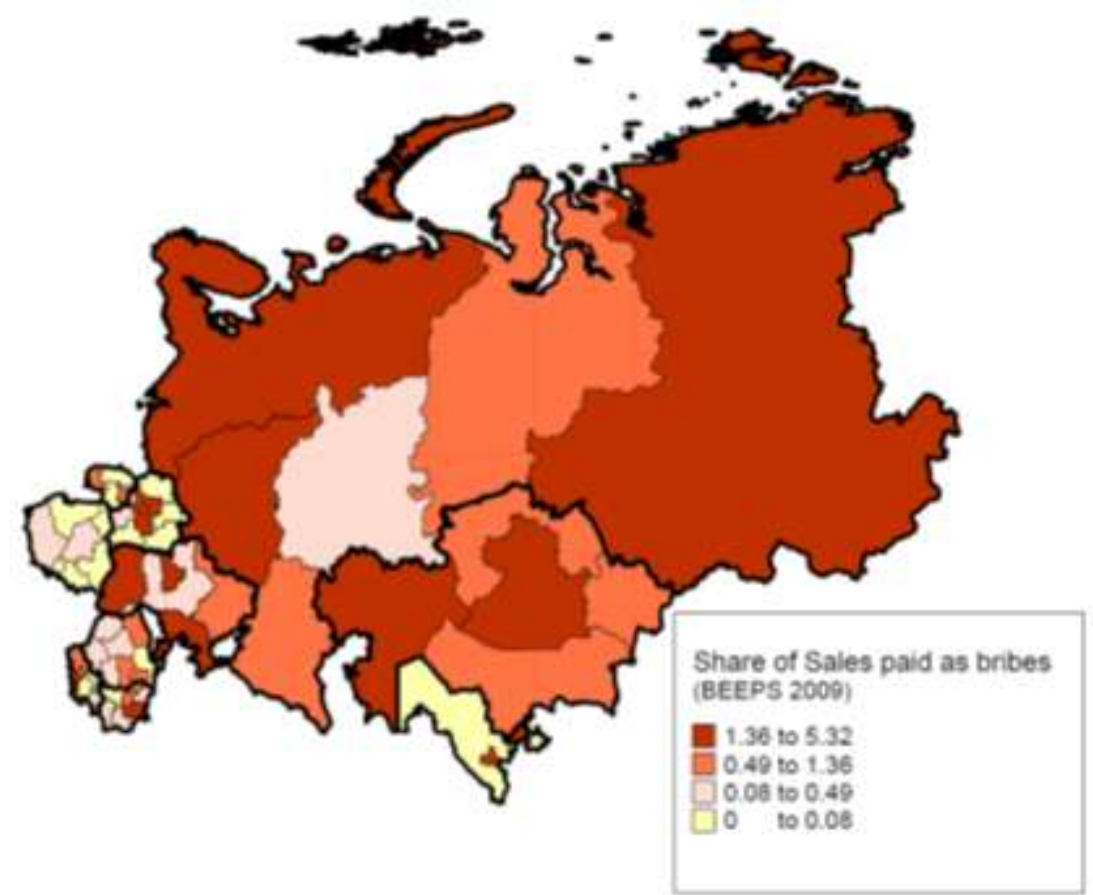

Figure1.b. Household assessment of the frequency of corruption (LITS 2006)

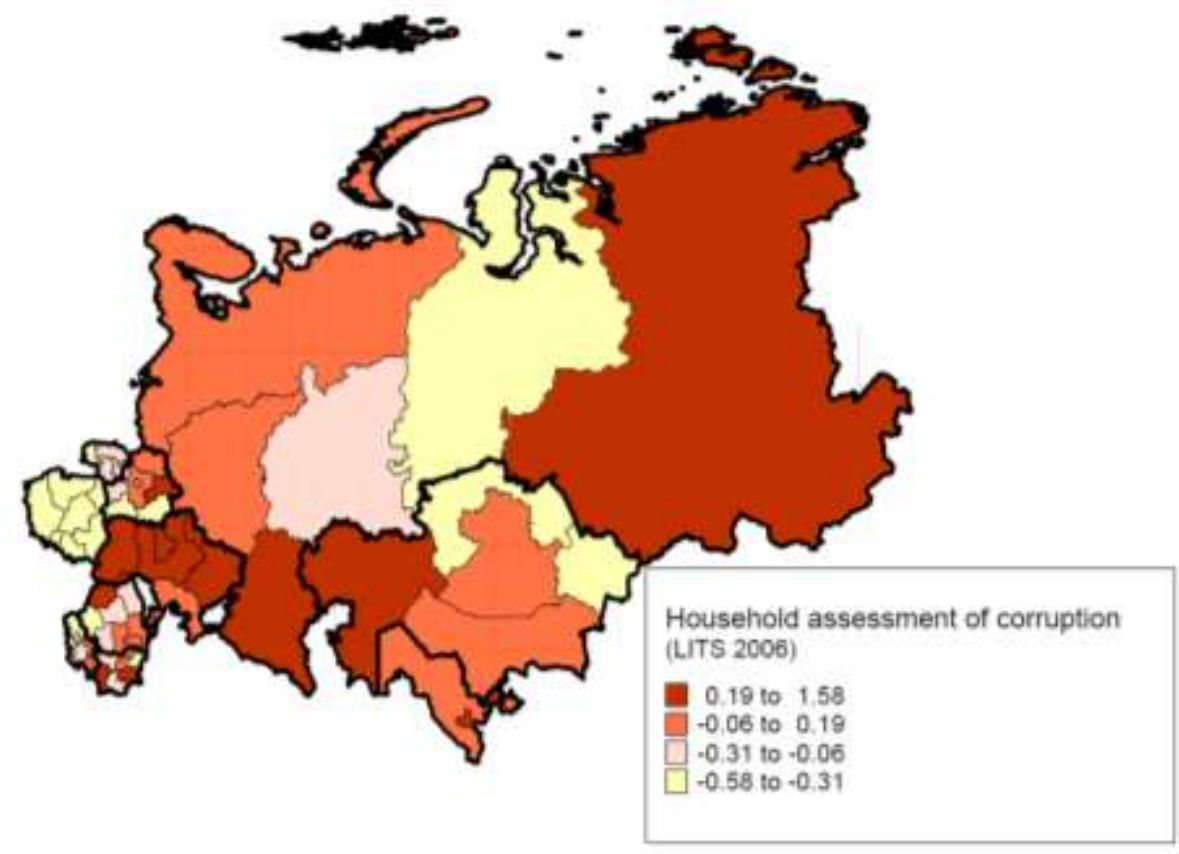

Note: Share of firm sales paid as bribes according to the BEEPS 2009 and household assessment of the frequency of corruption according to the LITS 2006. Far-East Russia is not included in the MOI sample and not represented on the map. The 56 regions are divided by quartiles. Darker colors represent higher levels of corruption.

Source: Authors' computations based on the BEEPS 2009 and LITS 2006 (EBRD-WB) and the Global Administrative Areas project. 
Figure 2. Corruption measures across transition countries in 2009

\section{2.a Perception of corruption (ICRG)}

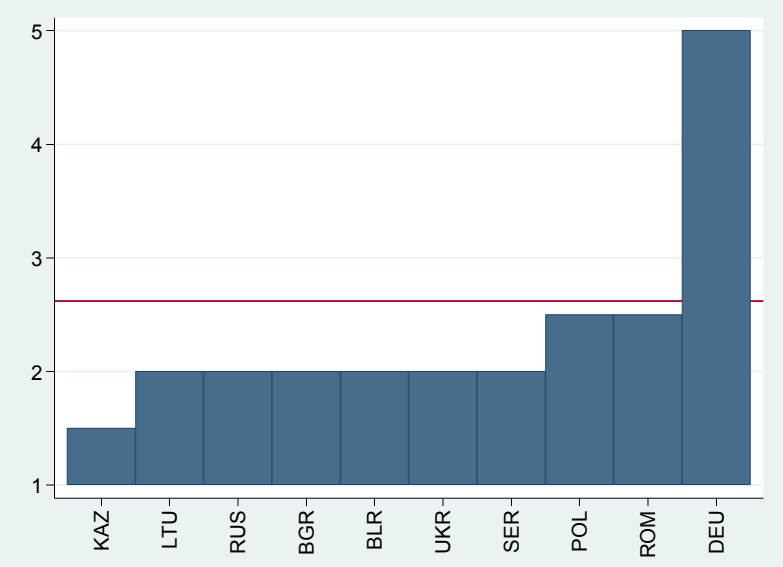

2.c. Share of firms' sales paid as bribes

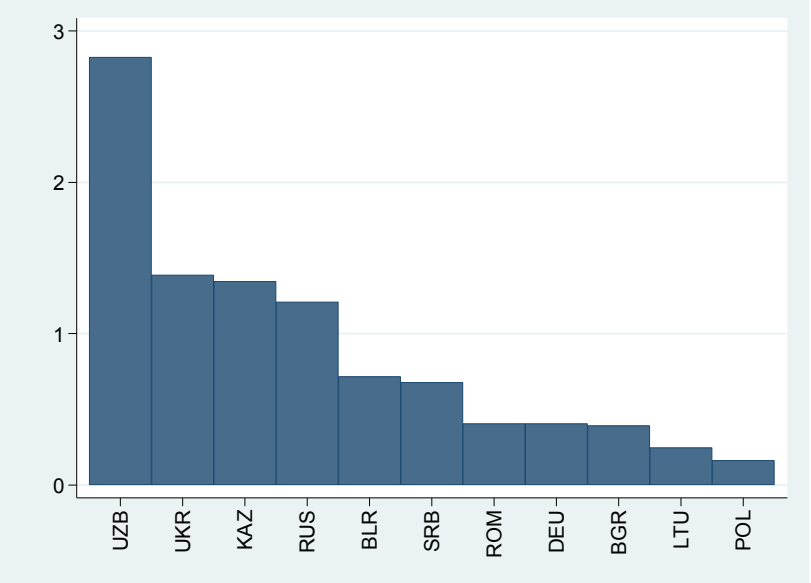

\section{2.b Perception of corruption (CPI)}

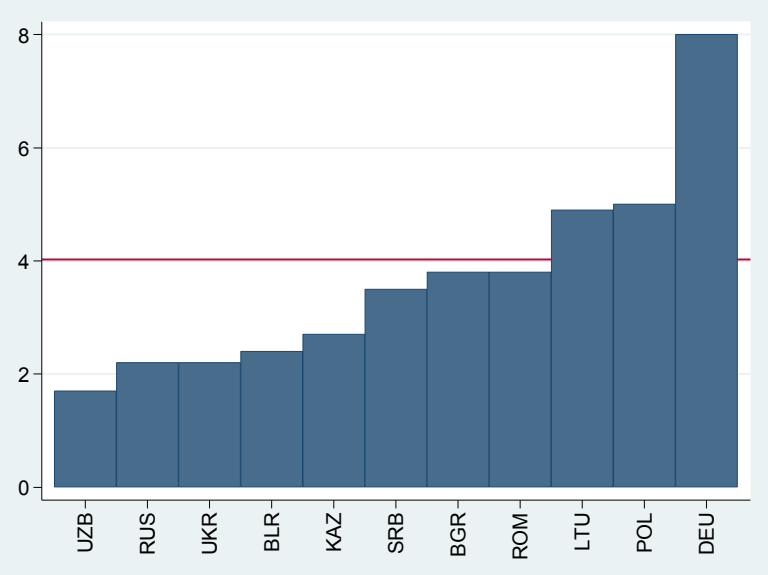

2.d. Households' frequency of bribes (2006)

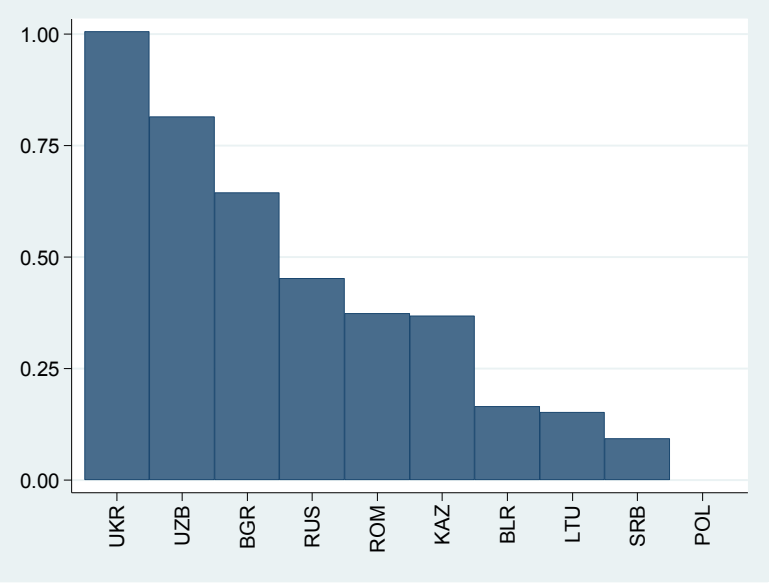

Note: Panel a displays the ICRG corruption perception index in 2009. Uzbekistan is not rated. Higher values indicate lower perceived corruption. Panel $b$ displays the Transparency International CPI index in 2009. Higher values indicate lower perceived corruption. Panel c displays the share of sales paid as bribes by manufacturing and service firms in 2009, except for Germany where the measure is from the 2005 survey. Median sampling weights are used. Panel d displays the average frequency of corruption according to local households from the LITS in 2006. It is an unweighted average of 8 questions related to the frequency of bribes when households meet civil servants. The scores are rescaled so that Poland has a score of 0 . Sampling weights are used.

The horizontal line represents the world average. BGR stands for Bulgaria, BLR for Belarus, DEU for Germany, KAZ for Kazakhstan, LTU for Lithuania, POL for Poland, ROM for Romania, RUS for Russia, SER for Serbia, UKR for Ukraine, and UZB for Uzbekistan.

Source: ICRG, Transparency International, BEEPS 2009 survey and LITS 2006 survey (EBRD-WB). 
Figure 3. Distribution of management practices and country averages

3.a. Distribution of the quality of management practices across establishments

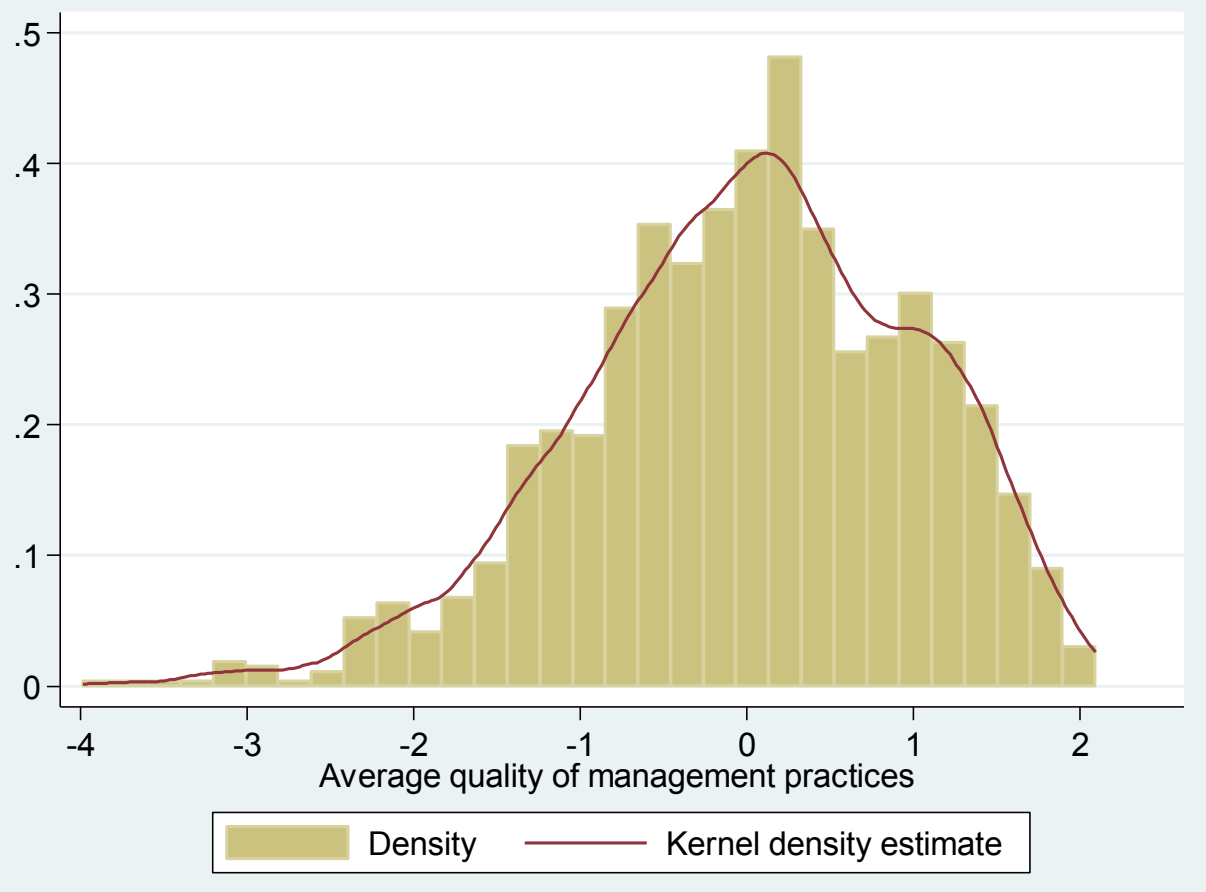

3.b. Average management practices at the country level

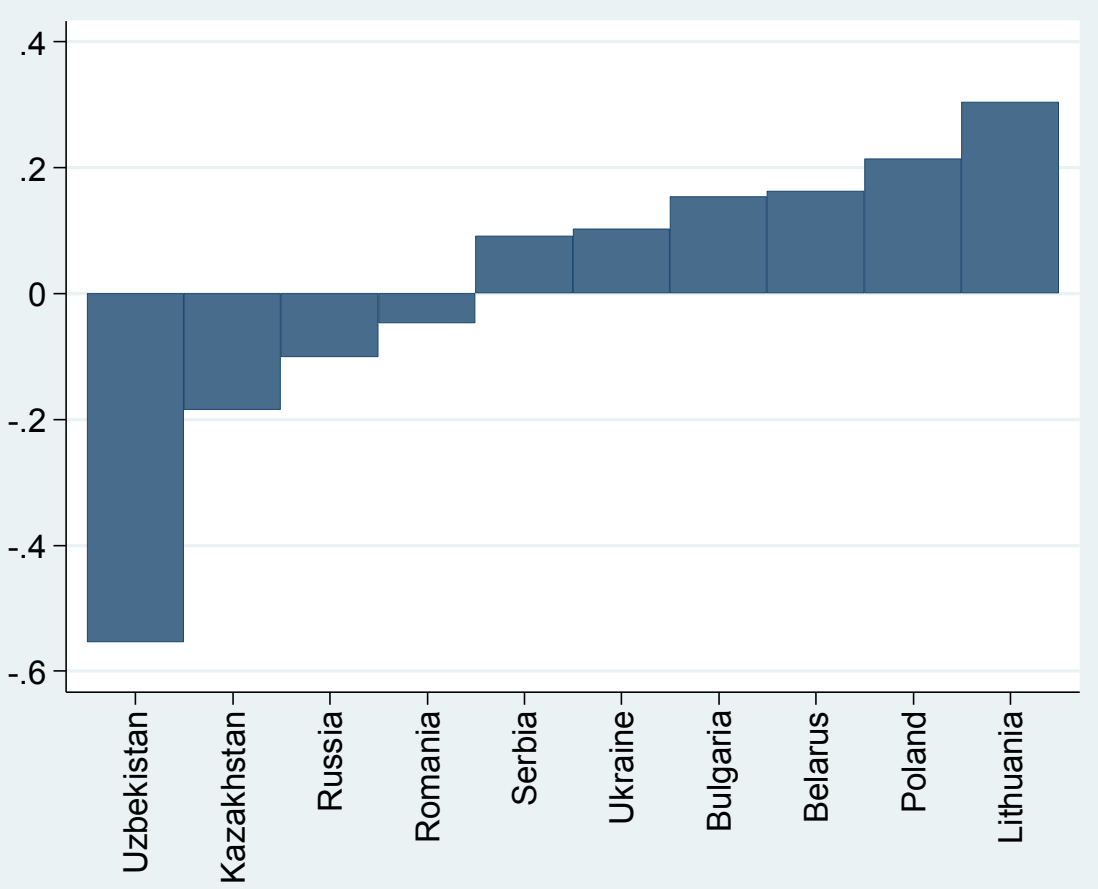

Note: The figure reports descriptive statistics for 1,355 manufacturing establishments. All scores of management quality are in deviation from the sample mean and have a standard-deviation of 1 . Figure 3.b displays the average management score in each country.

Source: MOI 2010 (EBRD-WB), and author's computations based on Bloom et al. (2012). 
Figure 4. Dependence on institutions by manufacturing sector
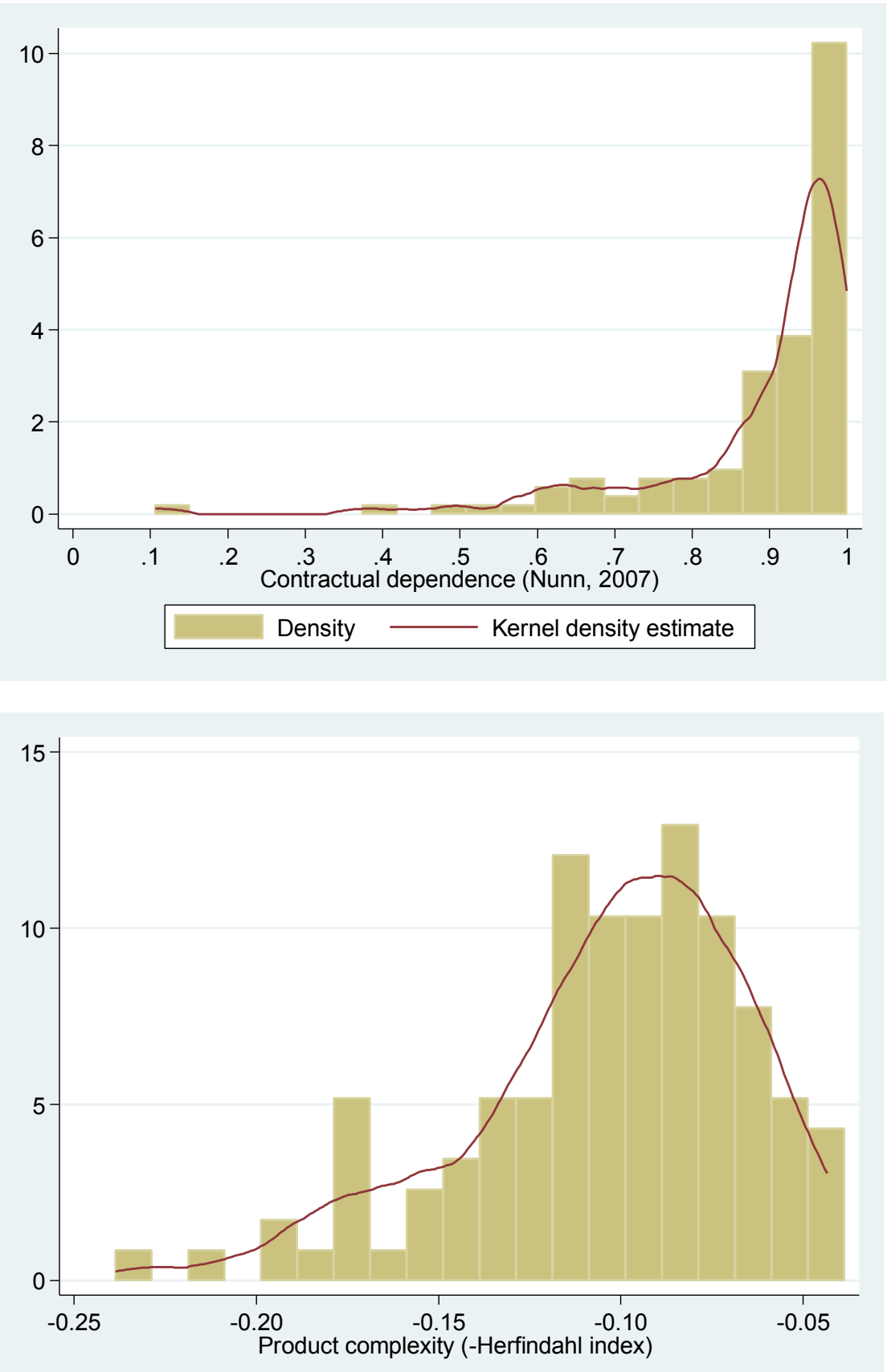

Note: Contract dependence of manufacturing sectors at the ISIC3.1 4 digits level. The measure is the share of relationship-specific inputs used by each US manufacturing sector in 1997. It is computed using Nunn (2007) share of inputs neither traded on open markets nor listed on leaflets at the 6-digit I-O classification level. It is converted to ISIC3.1 sectors using the BEA correspondence between the I-O classification and the NAICS 1997 and the BLS correspondence files between NAICS 1997 and 2002 and NAICS 2002 and ISIC3.1.

Source: Nunn (2007), Rauch (1999) and authors' computations based on BLS and BEA correspondence files. 
Figure 5. Management quality for high and low dependent to contract firms
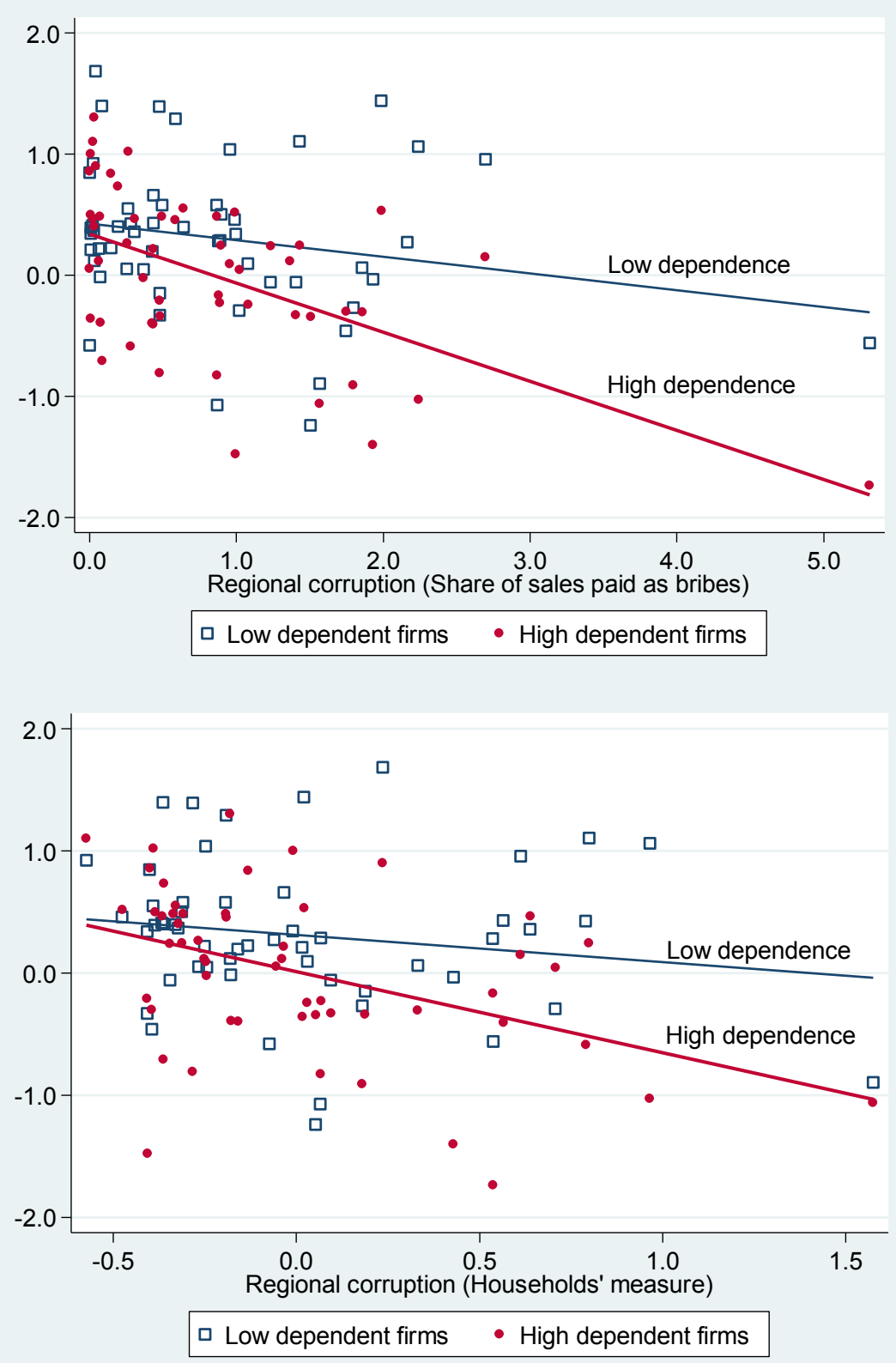

Note: High and low dependent to contract firms are the top and bottom quintile firms based on the US measure of contract dependence. The figure plots average regional management quality for the highest and lowest quintile of the distribution of contract dependent firms against corruption in the region. Each dot represents the average management quality in a region for the low dependence and high dependence groups. The two fitted lines represent the different effects of corruption on management quality for the low dependence and high dependence groups of firms.

Source: MOI survey, BEEPS 2009 and LITS 2006 (EBRD-WB), Nunn (2007), and authors' computations. 
Figure 6. Effect of contract dependence on management quality across regions
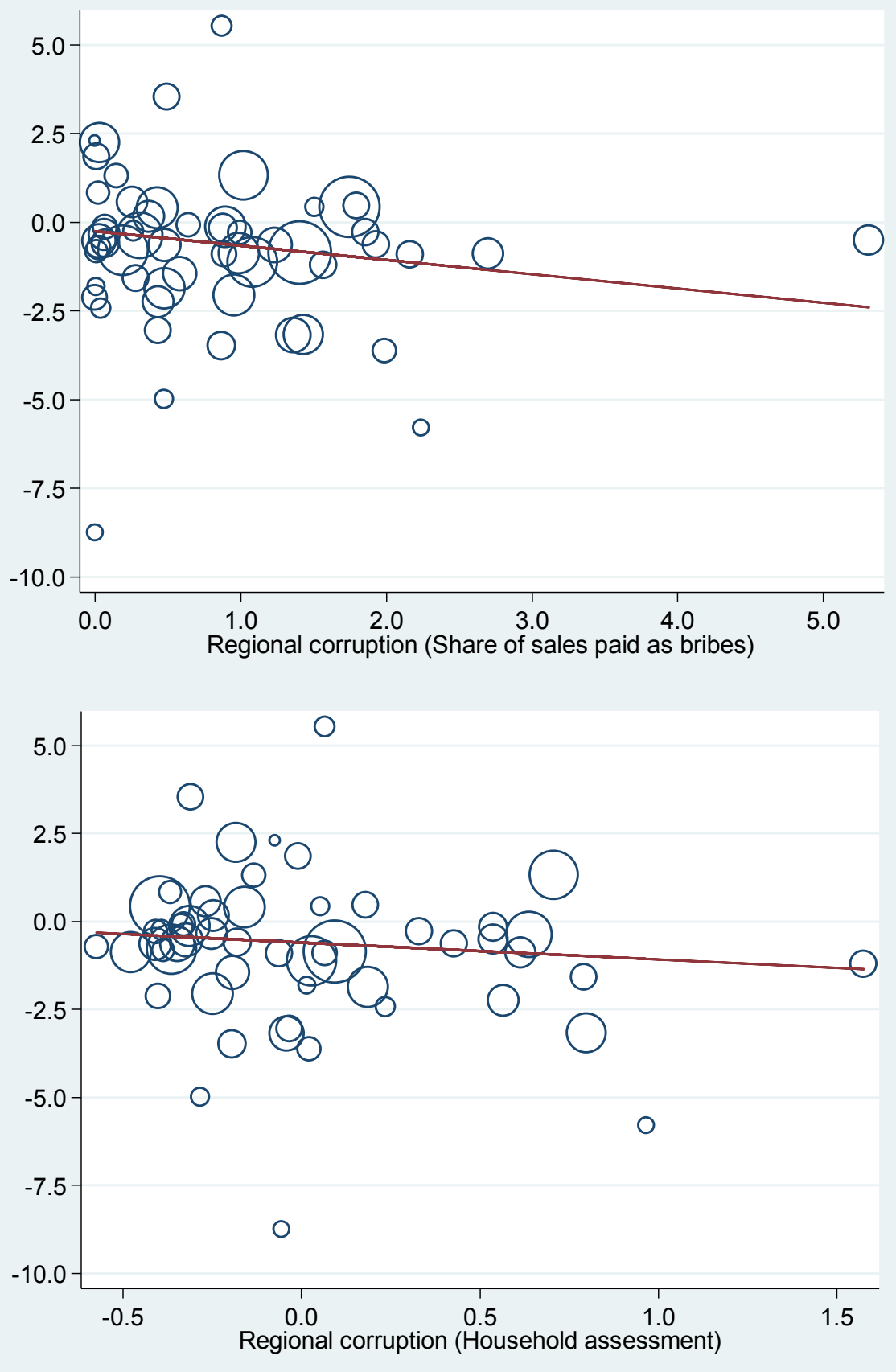

Note: For each region, we run a regression of management quality on the contract dependence of the firms. Each circle in Figure 6 represents a coefficient of one of these regressions, which is plotted against the household assessment of regional corruption. The size of the circle is the number of firms sampled in the MOI survey, with larger circles indicating more precise estimates. The straight line corresponds to the fitted line of a regression of the estimated effects of contract dependence on regional corruption. The regression is weighted by the square root of the number of firms in each region.

Source: MOI survey, BEEPS 2009 and LITS 2006 (EBRD-WB), Nunn (2007), and authors' computations. 
Figure 7. Estimated dependence on institutions by manufacturing sectors 7.a. 2-digit manufacturing sectors

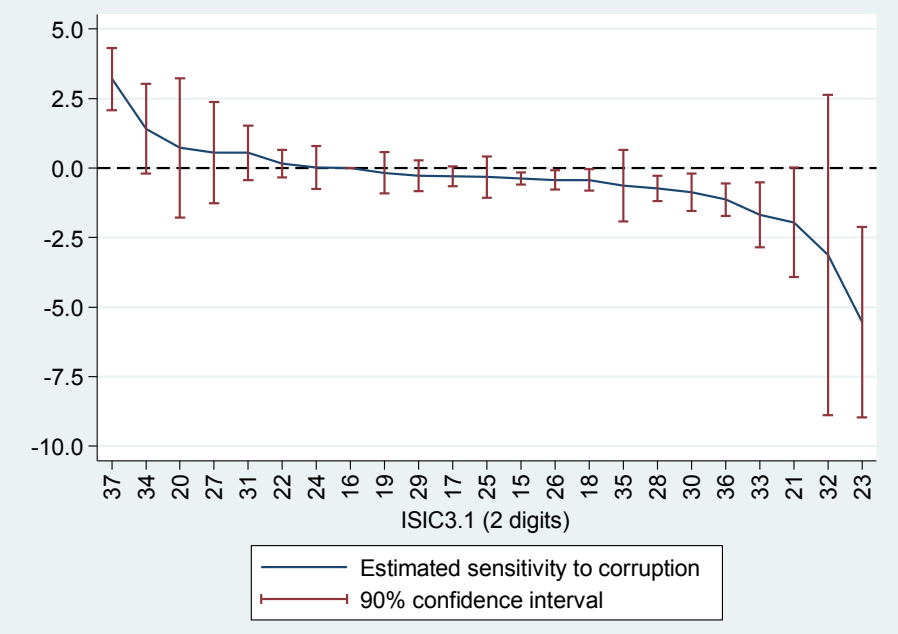

7.b. 3-digit manufacturing sectors

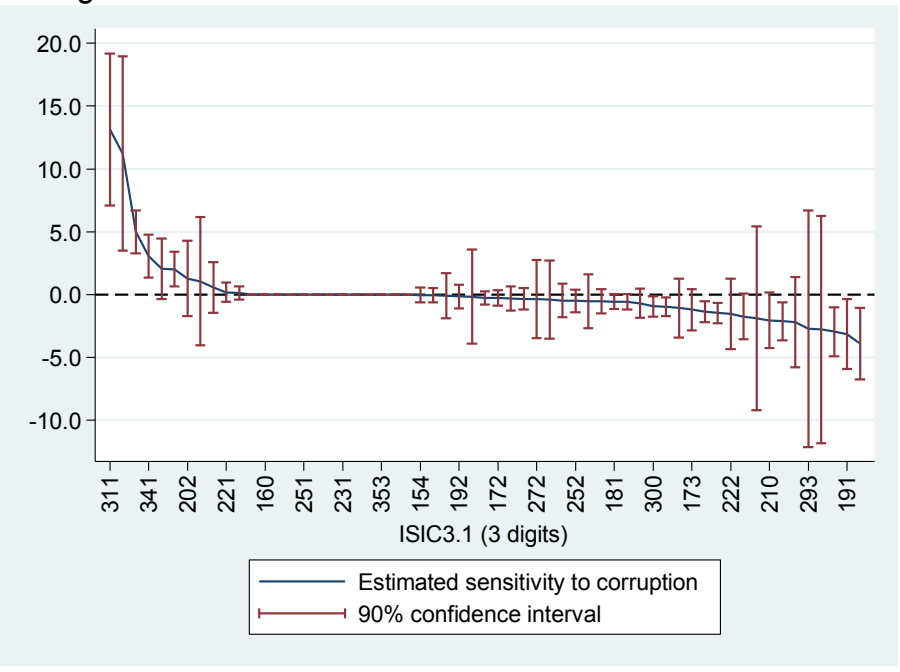

Note: The figure displays the estimates and the $90 \%$ confidence intervals for the differential effects of corruption on manufacturing sectors within a region. Formally, the model is, $Y_{\text {isrc }}=\alpha_{\mathrm{s}} \cdot \mathrm{C}_{\mathrm{rc}}+\mathrm{X}_{\mathrm{isrc}} \beta+\lambda_{\mathrm{sc}}+\delta_{\mathrm{rc}}+\varepsilon_{\text {isrc }}$, with $\lambda_{\mathrm{sc}}$, manufacturing sector times country fixed effects, and $\delta_{\mathrm{rc}}$, regional fixed effects. $\mathrm{C}_{\mathrm{rc}}$ is the household assessment of regional corruption according to the LITS (2006) and $\mathrm{X}_{\text {isrc }}$ a set of control variables. We report the estimated sensitivity of management practices to regional corruption, $\alpha_{s}$, for each manufacturing sector, s. The estimates are ranked by increasing order of sensitivity to regional corruption. The standard errors are clustered at the regional $\mathrm{x}$ industry level. The control variables include:

1. Noise controls: interviewer characteristics (gender, a quadratic function in age, highest degree completed) and interview characteristics ( 7 dummies for the days of the week, 4 dummies for the time of the day - morning, lunch time, afternoon or evening -, the duration of the interview in minutes, and a quadratic trend in the date of the interview allowing for business cycle effects).

2. Additional control variables include a quadratic function of size (number of full-time employees), a dummy for unknown size, dummy variables by type of ownership, dummy variables by size of municipality and a dummy variable if the establishment is part of a larger firm.

Source: MOI survey, BEEPS 2009 and LITS 2006 (EBRD-WB), and authors' computations. 
Figure 8. Sensitivity analysis: estimated effects of corruption using the difference-indifferences specification estimated by OLS or 2SLS dropping country one-by-one Figure 8.a. O LS estimates

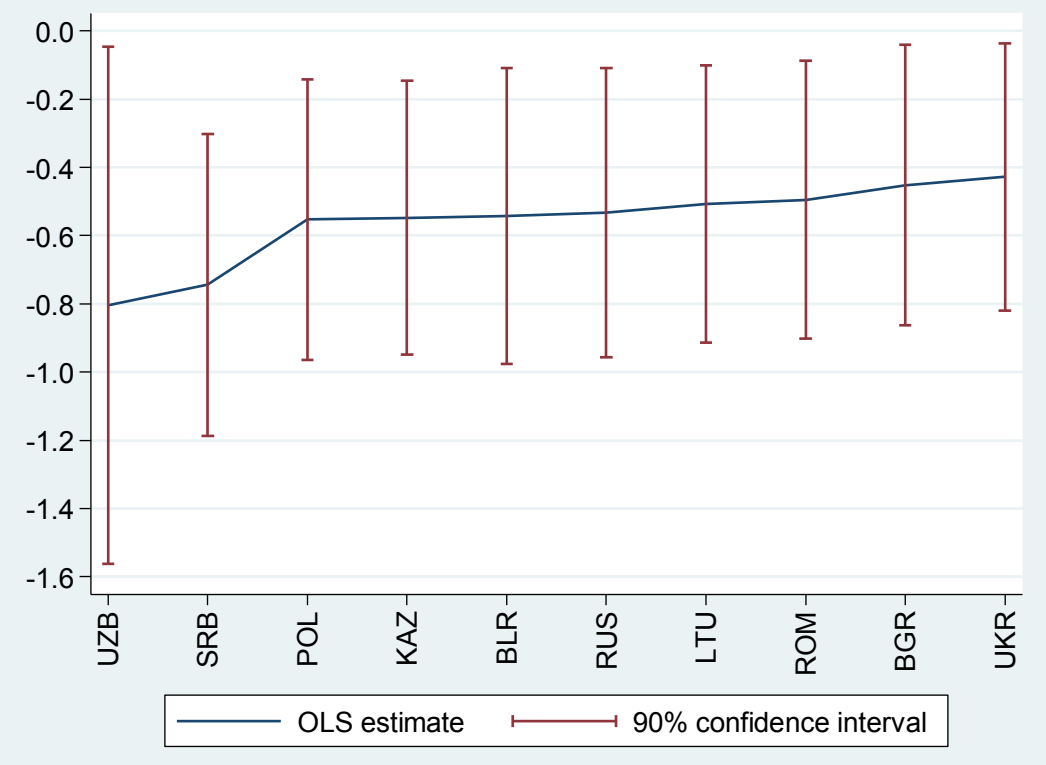

Figure 8.b. 2SLS estimates

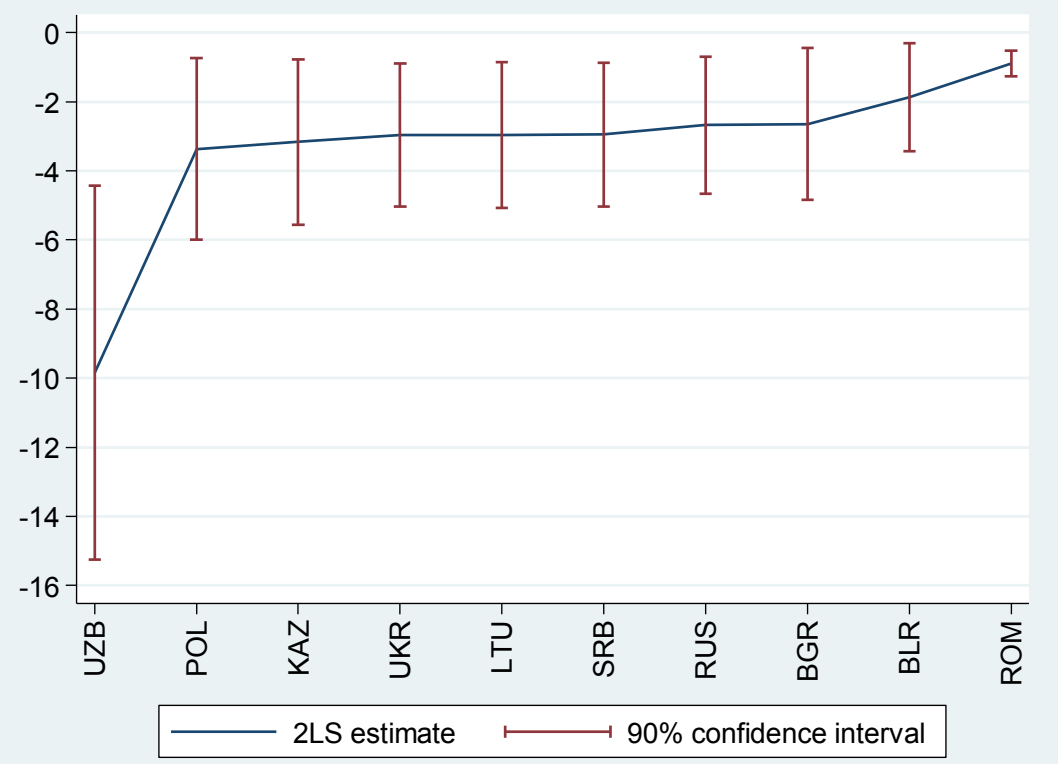

Note: The figure reports the estimates of the equation $Y_{\text {isrc }}=\alpha \cdot \exp _{\mathrm{s}} \cdot \mathrm{C}_{\mathrm{rc}}+\mathrm{X}_{\mathrm{isrc}} \beta+\lambda_{\mathrm{sc}}+\delta_{\mathrm{rc}}+\varepsilon_{\mathrm{isrc}}$, with $\lambda_{\mathrm{sc}}$, manufacturing sector times country fixed effects, and $\delta_{\mathrm{rc}}$, regional fixed effects. Exp $\mathrm{s}_{\mathrm{s}}$ is the measure of sensitivity to corruption computed using the US input-output table. $\mathrm{C}_{\mathrm{rc}}$ is the regional share of sales paid as bribes and $\mathrm{X}_{\text {isrc }}$ a set of control variables. The specification is estimated by OLS and 2SLS as in Tables 10 and 11. The countries are dropped oneby-one.

BGR stands for Bulgaria, BLR for Belarus, KAZ for Kazakhstan, LTU for Lithuania, POL for Poland, ROM for Romania, RUS for Russia, SER for Serbia, UKR for Ukraine, and UZB for Uzbekistan.

Source: MOI survey, BEEPS 2009 and LITS 2006 (EBRD-WB), Nunn (2007), and authors' computations. 


\begin{tabular}{|c|c|c|c|c|c|c|}
\hline & \multicolumn{5}{|c|}{ Descriptive statistics } & \multirow{2}{*}{$\begin{array}{c}\text { Variance } \\
\text { (Share of } \\
\text { variance within } \\
\text { country) }\end{array}$} \\
\hline & Mean & S.d. & Min & Max & Obs. & \\
\hline \multicolumn{7}{|l|}{ A. Firms' assessment of regional corruption } \\
\hline Share of sales paid as bribes & 0.83 & 0.93 & 0.00 & 5.31 & 56 & 0.67 \\
\hline Firms not answering the share of sales paid as bribes & 0.22 & 0.10 & 0.03 & 0.47 & 56 & 0.62 \\
\hline Frequency of bribes & -0.09 & 0.36 & -0.80 & 0.69 & 56 & 0.73 \\
\hline Firms not answering the frequency of bribes & 0.09 & 0.10 & 0.00 & 0.50 & 56 & 0.70 \\
\hline \multicolumn{7}{|c|}{ B. Households' assessment of corruption and government quality } \\
\hline Frequency of bribes & 0.01 & 0.43 & -0.57 & 1.57 & 56 & 0.75 \\
\hline Households not answering the frequency of bribes & 0.00 & 0.00 & 0.00 & 0.03 & 56 & 0.85 \\
\hline \multicolumn{7}{|l|}{ C. Sample size } \\
\hline \# firms by region (BEEPS2009) & 93.16 & 78.22 & 7 & 544 & 56 & 0.59 \\
\hline \# households by region (LITS2006) & 165.36 & 77.36 & 40 & 420 & 56 & 0.79 \\
\hline
\end{tabular}

Note: Observations are 56 regions. The frequency of bribes according to firms is the standardized value of the question "Is-it common for firms in my line of business to have to pay some irregular "additional payments or gifts" to get things done with regard to customs, taxes, licenses, regulations, services etc?" (BEEPS 2009, question ecaq39). The frequency of bribes according to households comes from 8 questions related to the frequency of bribes when households interact with the road police, request official documents, have other forms of interactions with the police, go to courts, receive public health care or public education, and request unemployment or social security benefits (LITS 2006, questions q313 1 to 8). The answers to each question are standardized and averaged. The final indicator is standardized at the household level. The share of sales paid by firms as bribes is the percentage of total annual sales paid as informal payment (BEEPS 2009, questions $\mathrm{j} 7 \mathrm{a}, \mathrm{j} 7 \mathrm{~b}$ and d2). Missing values are considered as missing at random. For each corruption indicator, higher values indicate higher levels of corruption.

Source: BEEPS 2009 and LITS 2006 (EBRD-WB), and authors' computations. 


\section{Table 2. Correlation between different measures of corruption at the regional level}

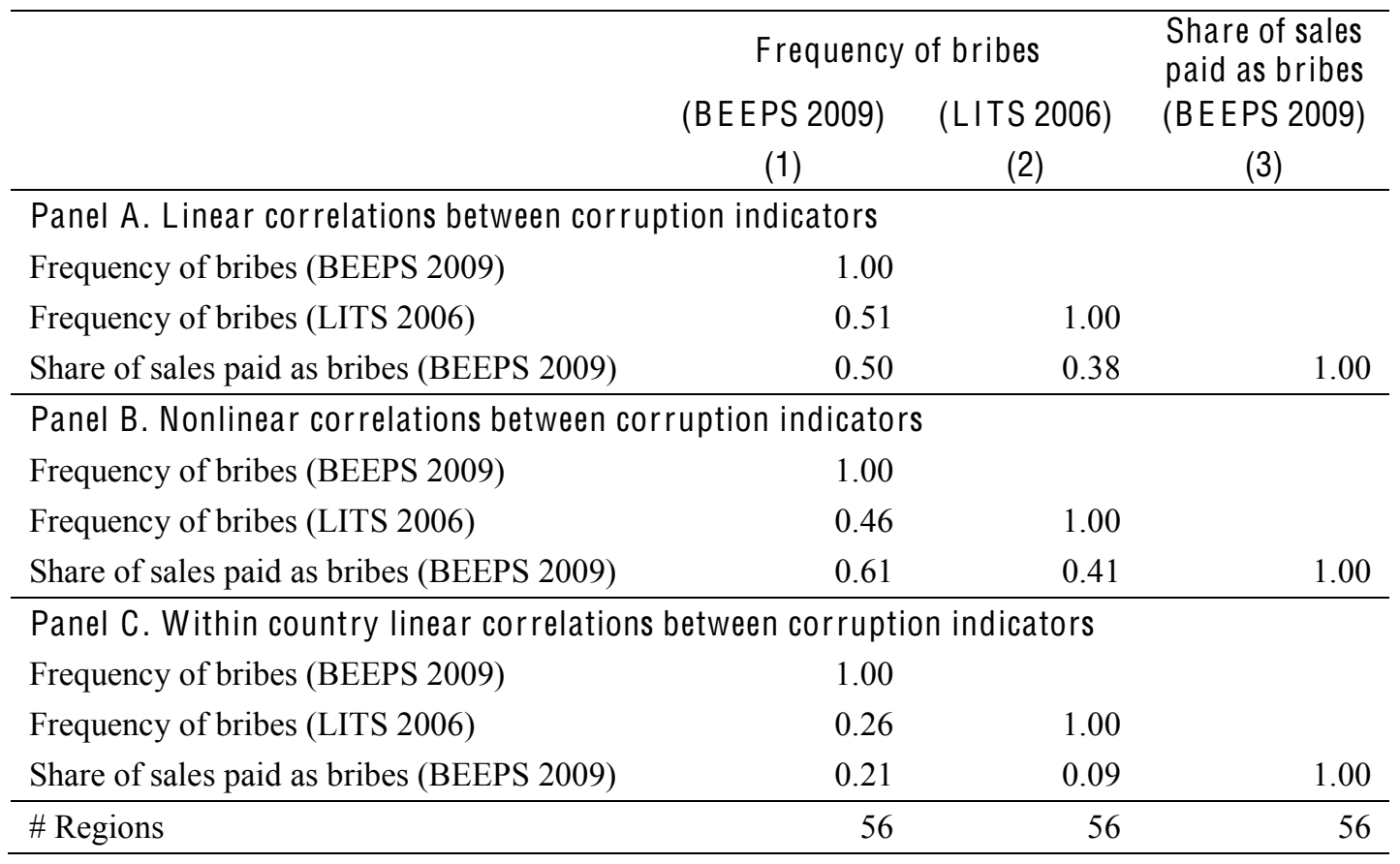

Note: Observations are 56 regions. The frequency of bribes according to firms is the standardized value of the question "Is-it common for firms in my line of business to have to pay some irregular "additional payments or gifts" to get things done with regard to customs, taxes, licenses, regulations, services etc?" (BEEPS 2009, question ecaq39). The frequency of bribes according to households comes from 8 questions related to the frequency of bribes when households interact with the road police, request official documents, have other forms of interactions with the police, go to courts, receive public health care or public education, and request unemployment or social security benefits (LITS 2006, questions q313 1 to 8). The answers to each question are standardized and averaged. The final indicator is standardized at the household level. The share of sales paid by firms as bribes is the percentage of total annual sales paid as informal payment (BEEPS 2009, questions $\mathrm{j} 7 \mathrm{a}, \mathrm{j} 7 \mathrm{~b}$ and $\mathrm{d} 2$ ). Missing values are considered as missing at random. For each corruption indicator, higher values indicate higher levels of corruption. Panel A displays linear correlations. Panel B displays Spearman rank correlations. Panel C displays linear correlations controlling for country fixed-effects (within country correlations).

Source: BEEPS 2009 and LITS 2006 (EBRD-WB), and authors' computations. 
Table 3. Descriptive statistics, sample of establishments

\begin{tabular}{|c|c|c|c|c|c|}
\hline & $\begin{array}{l}\text { Mean } \\
\text { (1) }\end{array}$ & $\begin{array}{l}\text { Std. Dev. } \\
\text { (2) }\end{array}$ & $\begin{array}{l}\text { Min } \\
(3)\end{array}$ & $\begin{array}{c}\operatorname{Max} \\
(4)\end{array}$ & $\begin{array}{l}\text { Obs. } \\
(5)\end{array}$ \\
\hline \multicolumn{6}{|l|}{ Panel A. Quality of management practices } \\
\hline Average & 0.00 & 1.00 & -3.99 & 2.09 & 1355 \\
\hline Operation & 0.00 & 1.00 & -4.48 & 0.81 & 1351 \\
\hline Monitoring & 0.00 & 1.00 & -3.53 & 1.72 & 1354 \\
\hline Targets & 0.00 & 1.00 & -1.94 & 1.32 & 1345 \\
\hline Incentives & 0.00 & 1.00 & -3.58 & 2.08 & 1354 \\
\hline \multicolumn{6}{|c|}{ Panel B. Internal organization of the establishments and other outcomes } \\
\hline Centralization of the decision process & 0.76 & 0.26 & 0.00 & 1.00 & 1355 \\
\hline Share of administrative employees & 0.26 & 0.17 & 0.01 & 1.00 & 1307 \\
\hline \multicolumn{6}{|l|}{ Share of college graduates among: } \\
\hline Production employees & 0.16 & 0.21 & 0.00 & 1.00 & 1201 \\
\hline Administrative employees & 0.51 & 0.34 & 0.00 & 1.00 & 1227 \\
\hline Innovation (new product in last 3 years) & 0.67 & 0.47 & 0.00 & 1.00 & 1348 \\
\hline R \& D spending over last fiscal year & 0.39 & 0.49 & 0.00 & 1.00 & 1320 \\
\hline 3 year averaged growth of employment ${ }^{1}$ & 1.75 & 16.79 & -111.66 & 116.89 & 1105 \\
\hline Establishment created less than 3 years ago & 0.02 & 0.13 & 0.00 & 1.00 & 1355 \\
\hline Main market: regional & 0.22 & 0.41 & 0.00 & 1.00 & 1343 \\
\hline Main market: international & 0.24 & 0.42 & 0.00 & 1.00 & 1343 \\
\hline \multicolumn{6}{|c|}{ Panel C. Basic controls for establishments' characteristics } \\
\hline Establishment is part of a larger firm & 0.18 & 0.38 & 0.00 & 1.00 & 1355 \\
\hline Size (full time employees) & 267.17 & 445.93 & 13 & 5403 & 1343 \\
\hline Size unknown & 0.01 & 0.09 & 0.00 & 1.00 & 1355 \\
\hline \multicolumn{6}{|l|}{ Ownership } \\
\hline Multiple Owners & 0.17 & 0.38 & 0.00 & 1.00 & 1355 \\
\hline Foreign & 0.14 & 0.34 & 0.00 & 1.00 & 1355 \\
\hline Family & 0.06 & 0.23 & 0.00 & 1.00 & 1355 \\
\hline Individual & 0.44 & 0.50 & 0.00 & 1.00 & 1355 \\
\hline State & 0.12 & 0.33 & 0.00 & 1.00 & 1355 \\
\hline \multicolumn{6}{|l|}{ City size (population) } \\
\hline Population over 1 million or capital city & 0.40 & 0.49 & 0.00 & 1.00 & 1355 \\
\hline Over 250,000 to 1 million inhabitants & 0.24 & 0.43 & 0.00 & 1.00 & 1355 \\
\hline 50,000 to 250,000 inhabitants & 0.27 & 0.44 & 0.00 & 1.00 & 1355 \\
\hline Less than 50,000 inhabitants & 0.09 & 0.29 & 0.00 & 1.00 & 1355 \\
\hline \multicolumn{6}{|l|}{ Panel D. Dependence to institutions } \\
\hline Contract dependence & 0.89 & 0.13 & 0.11 & 1.00 & 1355 \\
\hline Product complexity & -0.10 & 0.04 & -0.24 & -0.04 & 1355 \\
\hline
\end{tabular}

Note: The table reports descriptive statistics for 1,355 manufacturing establishments.

1 . The growth rate of employment takes only into account permanent full time employees.

Source: MOI survey (EBRD-WB), Nunn (2007), and authors' computations. 
Table 4. Corruption and difference in management practices across regions

\begin{tabular}{|c|c|c|c|c|c|c|}
\hline \multirow[t]{2}{*}{ Dependent variable: } & \multicolumn{6}{|c|}{ Average quality of management practices } \\
\hline & $(1)$ & $(2)$ & $(3)$ & (4) & $(5)$ & $(6)$ \\
\hline \multicolumn{7}{|c|}{ Panel A. Controlling for 10 manufacturing sectors } \\
\hline $\begin{array}{l}\text { Frequency of bribes } \\
\text { (BEEPS 2009) }\end{array}$ & $\begin{array}{c}-0.265^{* *} \\
(0.130)\end{array}$ & & & $\begin{array}{c}-0.288^{* *} \\
(0.123)\end{array}$ & & \\
\hline $\begin{array}{l}\text { Frequency of bribes } \\
\text { (LITS 2006) }\end{array}$ & & $\begin{array}{c}-0.253^{*} \\
(0.130)\end{array}$ & & & $\begin{array}{l}-0.203 \\
(0.127)\end{array}$ & \\
\hline $\begin{array}{l}\text { Share of sales paid as bribes } \\
\text { (BEEPS 2009) }\end{array}$ & & & $\begin{array}{l}-0.027 \\
(0.053)\end{array}$ & & & $\begin{array}{c}0.001 \\
(0.050)\end{array}$ \\
\hline R-square & 0.068 & 0.070 & 0.064 & 0.154 & 0.154 & 0.150 \\
\hline \multicolumn{7}{|c|}{ Panel B. Controlling for 22 manufacturing sectors } \\
\hline $\begin{array}{l}\text { Frequency of bribes } \\
\text { (BEEPS 2009) }\end{array}$ & $\begin{array}{c}-0.274 * * \\
(0.133)\end{array}$ & & & $\begin{array}{l}-0.269 * * \\
(0.133)\end{array}$ & & \\
\hline $\begin{array}{l}\text { Frequency of bribes } \\
\text { (LITS 2006) }\end{array}$ & & $\begin{array}{c}-0.260^{* *} \\
(0.128)\end{array}$ & & & $\begin{array}{l}-0.205 \\
(0.124)\end{array}$ & \\
\hline $\begin{array}{l}\text { Share of sales paid as bribes } \\
\text { (BEEPS 2009) }\end{array}$ & & & $\begin{array}{l}-0.024 \\
(0.054)\end{array}$ & & & $\begin{array}{l}0.026 \\
(0.051)\end{array}$ \\
\hline R-square & 0.086 & 0.088 & 0.082 & 0.204 & 0.204 & 0.200 \\
\hline \multicolumn{7}{|c|}{ Panel C. Controlling for 59 manufacturing sectors } \\
\hline $\begin{array}{l}\text { Frequency of bribes } \\
\text { (BEEPS 2009) }\end{array}$ & $\begin{array}{r}-0.264^{*} \\
(0.136)\end{array}$ & & & $\begin{array}{c}-0.273 * * \\
(0.135)\end{array}$ & & \\
\hline $\begin{array}{l}\text { Frequency of bribes } \\
\text { (LITS 2006) }\end{array}$ & & $\begin{array}{c}-0.264 * * \\
(0.130)\end{array}$ & & & $\begin{array}{l}-0.214^{*} \\
(0.127)\end{array}$ & \\
\hline $\begin{array}{l}\text { Share of sales paid as bribes } \\
\text { (BEEPS 2009) }\end{array}$ & & & $\begin{array}{l}-0.023 \\
(0.057)\end{array}$ & & & $\begin{array}{c}0.020 \\
(0.059)\end{array}$ \\
\hline R-square & 0.113 & 0.116 & 0.109 & 0.298 & 0.299 & 0.295 \\
\hline \multicolumn{7}{|c|}{ Panel D. Controlling for 59 manufacturing sectors and regional characteristics } \\
\hline $\begin{array}{l}\text { Frequency of bribes } \\
\text { (BEEPS 2009) }\end{array}$ & $\begin{array}{c}-0.346^{* *} \\
(0.133)\end{array}$ & & & $\begin{array}{c}-0.339 * * \\
(0.161)\end{array}$ & & \\
\hline $\begin{array}{l}\text { Frequency of bribes } \\
\text { (LITS 2006) }\end{array}$ & & $\begin{array}{c}-0.263 * * \\
(0.126)\end{array}$ & & & $\begin{array}{l}-0.247 * \\
(0.136)\end{array}$ & \\
\hline $\begin{array}{l}\text { Share of sales paid as bribes } \\
\text { (BEEPS 2009) }\end{array}$ & & & $\begin{array}{c}0.054 \\
(0.062)\end{array}$ & & & $\begin{array}{c}0.041 \\
(0.066)\end{array}$ \\
\hline $\begin{array}{l}\text { Out of labor force } \\
\text { (age 15-65) }\end{array}$ & $\begin{array}{l}-0.071 \\
(0.486)\end{array}$ & $\begin{array}{l}-0.200 \\
(0.505)\end{array}$ & $\begin{array}{c}0.241 \\
(0.523)\end{array}$ & $\begin{array}{c}0.385 \\
(0.678)\end{array}$ & $\begin{array}{c}0.344 \\
(0.609)\end{array}$ & $\begin{array}{c}0.758 \\
(0.678)\end{array}$ \\
\hline Primary education or below & -0.180 & -0.086 & 0.281 & -0.571 & -0.482 & -0.172 \\
\hline (age 15-65) & $(0.561)$ & $(0.477)$ & $(0.546)$ & $(0.567)$ & $(0.491)$ & $(0.547)$ \\
\hline \multirow[t]{2}{*}{ Individual trust } & 0.038 & 0.055 & 0.070 & 0.031 & 0.050 & 0.059 \\
\hline & $(0.150)$ & $(0.139)$ & $(0.155)$ & $(0.165)$ & $(0.152)$ & $(0.170)$ \\
\hline R-square & 0.322 & 0.323 & 0.319 & 0.300 & 0.300 & 0.296 \\
\hline Industry fixed effects & Yes & Yes & Yes & & & \\
\hline Country fixed effects & Yes & Yes & Yes & & & \\
\hline Industry $\mathrm{x}$ country fixed effects & & & & Yes & Yes & Yes \\
\hline Additional control variables & & & & Yes & Yes & Yes \\
\hline \# Observations & 1,355 & 1,355 & 1,355 & 1,355 & 1,355 & 1,355 \\
\hline \# clusters (regions) & 56 & 56 & 56 & 56 & 56 & 56 \\
\hline
\end{tabular}

Note: The table reports partial correlations and standard-errors for the difference in the quality of management practices. Additional control variables include a quadratic function of size (number of full-time employees), a dummy for unknown size, dummy variables by types of ownership, by size of municipality and a dummy variable if the establishment is part of a larger firm. Standard-errors are clustered at the regional level. * denote a significant estimate at the $10 \%$ level, $* *$ at $5 \%,{ }^{* * *}$ at $1 \%$.

Source: BEEPS 2009 and LITS 2006 (EBRD-WB), and authors' computations. 
Table 5. Falsification tests, contract dependence, concentration of inputs and managers' assessment of barriers to doing business

\begin{tabular}{|c|c|c|c|c|c|c|}
\hline & \multicolumn{6}{|c|}{$\begin{array}{l}\text { Linear probability model for stating that the following factors } \\
\text { A re a severe obstacle to doing business: }\end{array}$} \\
\hline & \multirow{2}{*}{$\begin{array}{c}\text { Corruption } \\
\text { (1) }\end{array}$} & \multicolumn{2}{|c|}{ Quality of courts } & \multirow{2}{*}{$\begin{array}{l}\text { Quality of } \\
\text { Courts } \\
\text { (4) }\end{array}$} & \multirow{2}{*}{$\begin{array}{c}\text { Political } \\
\text { instability } \\
(5)\end{array}$} & \multirow{2}{*}{$\begin{array}{c}\text { Crimes \& } \\
\text { disorders } \\
(6)\end{array}$} \\
\hline & & $\begin{array}{l}\text { Corrupt } \\
\text { (2) }\end{array}$ & $\begin{array}{c}\text { Slow } \\
(3)\end{array}$ & & & \\
\hline \multicolumn{7}{|l|}{ Panel A. } \\
\hline Contract dependence & $0.123^{* * *}$ & $0.467 * * *$ & 0.128 & $0.091 * *$ & $0.104^{*}$ & $0.110^{* *}$ \\
\hline (Nunn 2007) & $(0.043)$ & $(0.125)$ & $(0.170)$ & $(0.042)$ & $(0.061)$ & $(0.045)$ \\
\hline R-square & 0.070 & 0.114 & 0.128 & 0.049 & 0.093 & 0.070 \\
\hline \multicolumn{7}{|l|}{ Panel B. } \\
\hline Input diversification & 0.230 & -0.733 & 0.025 & 0.062 & 0.134 & -0.137 \\
\hline (-Herfindahl in 1997) & $(0.240)$ & $(0.565)$ & $(0.589)$ & $(0.181)$ & $(0.246)$ & $(0.165)$ \\
\hline R-square & 0.069 & 0.111 & 0.128 & 0.048 & 0.092 & 0.068 \\
\hline Regional fixed effects & Yes & Yes & Yes & Yes & Yes & Yes \\
\hline Observations & 2,252 & 2,131 & 2,178 & 2,186 & 2,328 & 2,353 \\
\hline \multirow[t]{2}{*}{ Manufacturing sectors } & 114 & 114 & 114 & 114 & 114 & 114 \\
\hline & $\begin{array}{l}\text { Licensing } \\
\& \text { permits } \\
(1)\end{array}$ & $\begin{array}{c}\text { Taxes } \\
(2) \\
\end{array}$ & $\begin{array}{c}\text { Tax admi- } \\
\text {-nistration } \\
(3) \\
\end{array}$ & $\begin{array}{c}\text { Access to } \\
\text { finance } \\
(4)\end{array}$ & $\begin{array}{c}\text { Transport } \\
\text { network } \\
(5) \\
\end{array}$ & $\begin{array}{c}\text { Education } \\
\text { labor force } \\
(6)\end{array}$ \\
\hline \multicolumn{7}{|l|}{ Panel C. } \\
\hline $\begin{array}{l}\text { Contract dependence } \\
\text { (Nunn 2007) }\end{array}$ & $\begin{array}{c}0.027 \\
(0.036)\end{array}$ & $\begin{array}{c}0.078 \\
(0.090)\end{array}$ & $\begin{array}{c}0.034 \\
(0.046)\end{array}$ & $\begin{array}{c}0.087 \\
(0.069)\end{array}$ & $\begin{array}{l}-0.097 \\
(0.067)\end{array}$ & $\begin{array}{l}0.123^{*} \\
(0.065)\end{array}$ \\
\hline R-square & 0.045 & 0.079 & 0.056 & 0.063 & 0.064 & 0.065 \\
\hline \multicolumn{7}{|l|}{ Panel D. } \\
\hline Input diversification & $-0.330 * *$ & 0.212 & -0.122 & -0.143 & $-0.425 * *$ & 0.294 \\
\hline (-Herfindahl in 1997) & $(0.142)$ & $(0.292)$ & $(0.157)$ & $(0.238)$ & $(0.171)$ & $(0.192)$ \\
\hline R-square & 0.046 & 0.079 & 0.056 & 0.063 & 0.065 & 0.064 \\
\hline Regional fixed effects & Yes & Yes & Yes & Yes & Yes & Yes \\
\hline Observations & 2,255 & 2,410 & 2,390 & 2,350 & 2,367 & 2,369 \\
\hline Manufacturing sectors & 114 & 114 & 114 & 114 & 114 & 114 \\
\hline
\end{tabular}

Note: The table reports the estimates of a linear probability model of a dummy variable for stating that a particular factor is a severe obstacle to doing business on a US measure of contract dependence and a US measure of input diversification controlling for regional fixed effects. More precisely, the observations are managers' assessments of the obstacles to doing business in 10 transition countries. The dependent variable takes value one if the manager declares that the factor is a very severe obstacle to doing business. Non responses and refusals are treated as missing values. The wording of the question is: "As I list some factors that can affect the current operations of a business, please look at this card and tell me if you think that each factor is No Obstacle, a Minor Obstacle, a Moderate Obstacle, a Major Obstacle, or a Very Severe Obstacle to the current operations of this establishment." Standarderrors are clustered at the manufacturing sector level. * denote a significant estimate at the $10 \%$ level, $* *$ at $5 \%, * * *$ at $1 \%$.

Source: BEEPS 2009 (EBRD-WB), Nunn (2007), and authors' computations. 
Table 6. Non parametric tests for differential effects of corruption within regions across manufacturing sectors

\begin{tabular}{|c|c|c|c|c|c|c|}
\hline \multirow[t]{2}{*}{ Dependent variable: } & \multicolumn{6}{|c|}{ Average quality of management practices } \\
\hline & $(1)$ & $(2)$ & $(3)$ & $(4)$ & $(5)$ & (6) \\
\hline \multicolumn{7}{|c|}{ Panel A. Controlling for 10 manufacturing sectors } \\
\hline F-test frequency of bribes & 2.977 & & & 2.801 & & \\
\hline (BEEPS 2009) [p-value] & {$[0.001]$} & & & {$[0.002]$} & & \\
\hline F-test frequency of bribes & & 2.796 & & & $\begin{array}{l}2.805 \\
{[0.002]}\end{array}$ & \\
\hline F-test share of sales paid as bribes & & & 2.776 & & & 2.027 \\
\hline (BEEPS 2009) [p-value] & & & [0.003] & & & {$[0.030]$} \\
\hline R-square & 0.203 & 0.197 & 0.198 & 0.235 & 0.231 & 0.231 \\
\hline \multicolumn{7}{|c|}{ Panel B. Controlling for 22 manufacturing sectors } \\
\hline F-test frequency of bribes & 1.800 & & & 1.682 & & \\
\hline (BEEPS 2009) [p-value] & {$[0.017]$} & & & [0.031] & & \\
\hline F-test frequency of bribes & & 4.120 & & & 4.665 & \\
\hline (LITS 2006) [p-value] & & {$[0.000]$} & & & {$[0.000]$} & \\
\hline F-test share of sales paid as bribes & & & 5.100 & & & 4.062 \\
\hline (BEEPS 2009) [p-value] & & & {$[0.000]$} & & & {$[0.000]$} \\
\hline R-square & 0.254 & 0.260 & 0.264 & 0.283 & 0.292 & 0.290 \\
\hline \multicolumn{7}{|c|}{ Panel C. Controlling for 59 manufacturing sectors } \\
\hline F-test frequency of bribes & 5.768 & & & 3.635 & & \\
\hline (BEEPS 2009) [p-value] & [0.000] & & & [0.000] & & \\
\hline F-test frequency of bribes & & 7.908 & & & $\begin{array}{l}4.471 \\
{[0.0001}\end{array}$ & \\
\hline $\begin{array}{l}\text { (LITS 2006) [p-value] } \\
\text { F-test share of sales paid as bribes }\end{array}$ & & {$[0.000]$} & & & & 14.75 \\
\hline (BEEPS 2009) [p-value] & & & {$[0.000]$} & & & {$[0.000]$} \\
\hline R-square & 0.362 & 0.366 & 0.373 & 0.386 & 0.391 & 0.398 \\
\hline Industry $\mathrm{x}$ country fixed effects & Yes & Yes & Yes & Yes & Yes & Yes \\
\hline Regional fixed effects & Yes & Yes & Yes & Yes & Yes & Yes \\
\hline Noise controls & & & & Yes & Yes & Yes \\
\hline Additional control variables & & & & Yes & Yes & Yes \\
\hline \# Observations & 1,355 & 1,355 & 1,355 & 1,355 & 1,355 & 1,355 \\
\hline \# clusters (regions x 11 sectors) & 385 & 385 & 385 & 385 & 385 & 385 \\
\hline
\end{tabular}

Note: The table reports F-test and its p-value for the differential effect of corruption on manufacturing sectors within a region. Formally, the model is, $Y_{\text {isrc }}=\alpha_{s} \cdot C_{\mathrm{rc}}+X_{\text {isrc }} \beta+\lambda_{\text {sc }}+\delta_{\text {rc }}+\varepsilon_{\text {isrc }}$, with $\lambda_{\mathrm{sc}}$, manufacturing sector times country fixed effects, and $\delta_{\mathrm{rc}}$, regional fixed effects. $\alpha_{\mathrm{s}}$ is the measure of sensitivity to corruption of manufacturing sector $\mathrm{s}$. $\mathrm{C}_{\mathrm{rc}}$ is our measure of corruption and $X_{\text {isrc }}$ a set of control variables. We test Ho: for all $s, \alpha s=\alpha$. The F-test is clustered at the regional $\mathrm{x}$ industry level. A p-value below 0.1 denotes a rejection of the null hypothesis of equal sensitivity to corruption at the $10 \%$ level, below 0.05 at $5 \%$, below 0.01 at $1 \%$, respectively.

1. Noise controls: interviewer characteristics (gender, a quadratic function in age, highest degree completed) and interview characteristics ( 7 dummies for the days of the week, 4 dummies for the time of the day - morning, lunch time, afternoon or evening -, the duration of the interview in minutes, and a quadratic trend in the date of the interview allowing for business cycle effects).

2. Additional control variables include a quadratic function of size (number of full-time employees), a dummy for unknown size, dummy variables by type of ownership, dummy variables by size of municipality and a dummy variable if the establishment is part of a larger firm.

Source: MOI survey, BEEPS 2009 and LITS 2006 (EBRD-WB), and authors' computations. 
Table 7. Difference-in-differences estimates by contract-dependence of the manufacturing sectors

\begin{tabular}{|c|c|c|c|c|c|c|}
\hline \multirow[t]{2}{*}{ Dependent variable: } & \multicolumn{6}{|c|}{ Average quality of management practices } \\
\hline & (1) & (2) & (3) & (4) & (5) & (6) \\
\hline \multicolumn{7}{|c|}{ Panel A. Controlling for 10 manufacturing sectors } \\
\hline $\begin{array}{c}\text { Frequency of bribes (BEEPS 2009) } \\
\text { x Contract dependence }\end{array}$ & $\begin{array}{l}-0.618 \\
(1.158)\end{array}$ & & & $\begin{array}{c}-0.682 \\
(1.269)\end{array}$ & & \\
\hline Frequency of bribes (LITS 2006) & & $-1.451 * * *$ & & & $-1.583 * * *$ & \\
\hline x Contract dependence & & $(0.551)$ & & & $(0.579)$ & \\
\hline $\begin{array}{l}\text { Share of sales paid as bribes } \\
\text { x Contract dependence }\end{array}$ & & & $\begin{array}{c}-0.722 * * \\
(0.286)\end{array}$ & & & $\begin{array}{c}-0.719 * * \\
(0.313)\end{array}$ \\
\hline R-square & 0.191 & 0.193 & 0.193 & 0.225 & 0.226 & 0.226 \\
\hline \multicolumn{7}{|c|}{ Panel B. Controlling for 22 manufacturing sectors } \\
\hline $\begin{array}{c}\text { Frequency of bribes (BEEPS 2009) } \\
\text { x Contract dependence }\end{array}$ & $\begin{array}{l}-1.106 \\
(1.156)\end{array}$ & & & $\begin{array}{l}-1.195 \\
(1.252)\end{array}$ & & \\
\hline Frequency of bribes (LITS 2006) & & $-1.406^{* * *}$ & & & $-1.507 * * *$ & \\
\hline x Contract dependence & & $(0.529)$ & & & $(0.561)$ & \\
\hline $\begin{array}{l}\text { Share of sales paid as bribes } \\
\text { x Contract dependence }\end{array}$ & & & $\begin{array}{l}-0.529 * \\
(0.312)\end{array}$ & & & $\begin{array}{l}-0.465 \\
(0.346)\end{array}$ \\
\hline R-square & 0.244 & 0.245 & 0.244 & 0.273 & 0.275 & 0.274 \\
\hline \multicolumn{7}{|c|}{ Panel C. Controlling for 59 manufacturing sectors } \\
\hline $\begin{array}{c}\text { Frequency of bribes (BEEPS 2009) } \\
\text { x Contract dependence }\end{array}$ & $\begin{array}{l}-0.252 \\
(0.906)\end{array}$ & & & $\begin{array}{r}-0.242 \\
(1091)\end{array}$ & & \\
\hline Frequency of bribes (LITS 2006) & & $-1.438 * *$ & & & $-1.559 * *$ & \\
\hline x Contract dependence & & $(0.688)$ & & & $(0.720)$ & \\
\hline $\begin{array}{l}\text { Share of sales paid as bribes } \\
\text { x Contract dependence }\end{array}$ & & & $\begin{array}{l}-0.511 \\
(0.395)\end{array}$ & & & $\begin{array}{l}-0.445 \\
(0.446)\end{array}$ \\
\hline R-square & 0.343 & 0.345 & 0.344 & 0.367 & 0.369 & 0.368 \\
\hline Industry $\mathrm{x}$ country fixed effects & Yes & Yes & Yes & Yes & Yes & Yes \\
\hline Regional fixed effects & Yes & Yes & Yes & Yes & Yes & Yes \\
\hline Noise controls & & & & Yes & Yes & Yes \\
\hline Additional control variables & & & & Yes & Yes & Yes \\
\hline \# Observations & 1,355 & 1,355 & 1,355 & 1,355 & 1,355 & 1,355 \\
\hline \# clusters (regions $\mathrm{x}$ industry) & 386 & 386 & 386 & 386 & 386 & 386 \\
\hline
\end{tabular}

Note: The table reports the estimates of the equation $Y_{\text {isrc }}=\alpha \cdot \exp _{\mathrm{s}} \cdot \mathrm{C}_{\mathrm{rc}}+\mathrm{X}_{\mathrm{isc}} \beta+\lambda_{\mathrm{sc}}+\delta_{\mathrm{rc}}+\varepsilon_{\mathrm{isc}}$, with $\lambda_{\mathrm{sc}}$, manufacturing sector times country fixed effects, and $\delta_{\mathrm{rc}}$, regional fixed effects. $\operatorname{Exp}_{\mathrm{s}}$ is the measure of sensitivity to corruption computed using the US input-output table. $\mathrm{C}_{\mathrm{rc}}$ is our measure of corruption and $\mathrm{X}_{\mathrm{isrc}}$ a set of control variables.

1. Noise controls: interviewer characteristics (gender, a quadratic function in age, highest degree completed) and interview characteristics (7 dummies for the days of the week, 4 dummies for the time of the day - morning, lunch time, afternoon or evening -, the duration of the interview in minutes, and a quadratic trend in the date of the interview allowing for business cycle effects).

2. Additional control variables include a quadratic function of size (number of full-time employees), a dummy for unknown size, dummy variables by type of ownership, dummy variables by size of municipality and a dummy variable if the establishment is part of a larger firm.

Source: MOI survey, BEEPS 2009 and LITS 2006 (EBRD-WB), Nunn (2007), and authors' computations. 
Table 8. Difference-in-differences estimates by contract-dependence of the manufacturing sectors correcting for US benchmarking bias

\begin{tabular}{|c|c|c|c|c|c|c|}
\hline \multirow[t]{2}{*}{ Dependent variable: } & \multicolumn{6}{|c|}{ Average quality of management practices } \\
\hline & (1) & $(2)$ & (3) & (4) & (5) & (6) \\
\hline \multicolumn{7}{|c|}{ Panel A. Controlling for 10 manufacturing sectors } \\
\hline Frequency of bribes (BEEPS 2009) & -1.080 & & & -1.138 & & \\
\hline x Contract dependence & $(0.767)$ & & & $(0.847)$ & & \\
\hline Frequency of bribes (LITS 2006) & & $-1.207 * * *$ & & & $-1.288 * * *$ & \\
\hline x Contract dependence & & $(0.429)$ & & & $(0.454)$ & \\
\hline $\begin{array}{l}\text { Share of sales paid as bribes } \\
\text { x Contract dependence }\end{array}$ & & & $\begin{array}{c}-0.467 * * \\
(0.212)\end{array}$ & & & $\begin{array}{c}-0.462 * * \\
(0.222)\end{array}$ \\
\hline \multicolumn{7}{|c|}{ Panel B. Controlling for 22 manufacturing sectors } \\
\hline $\begin{array}{c}\text { Frequency of bribes (BEEPS 2009) } \\
\text { x Contract denendence }\end{array}$ & $-2.651 * *$ & & & $-1.406^{*}$ & & \\
\hline Frequency of bribes (LITS 2006) & & $-1.259 * * *$ & & & $-1.239 * * *$ & \\
\hline x Contract dependence & & $(0.399)$ & & & $(0.420)$ & \\
\hline $\begin{array}{l}\text { Share of sales paid as bribes } \\
\text { x Contract dependence }\end{array}$ & & & $\begin{array}{c}-0.575 * * \\
(0.231)\end{array}$ & & & $\begin{array}{c}-0.504 * * \\
(0.248)\end{array}$ \\
\hline \multicolumn{7}{|c|}{ Panel C. Controlling for 59 manufacturing sectors } \\
\hline Frequency of bribes (BEEPS 2009) & -0.837 & & & -1.259 & & \\
\hline $\begin{array}{c}\text { x Contract dependence } \\
\text { Frequency of bribes (LITS 2006) }\end{array}$ & $(0.728)$ & $-1.358 * * *$ & & $(1.009)$ & $-1.419 * * *$ & \\
\hline x Contract dependence & & $(0.412)$ & & & $(0.433)$ & \\
\hline $\begin{array}{l}\text { Share of sales paid as bribes } \\
\text { x Contract dependence }\end{array}$ & & & $\begin{array}{c}-0.516^{* *} \\
(0.245)\end{array}$ & & & $\begin{array}{r}-0.445^{*} \\
(0.263)\end{array}$ \\
\hline Industry $\mathrm{x}$ country fixed effects & Yes & Yes & Yes & Yes & Yes & Yes \\
\hline Regional fixed effects & Yes & Yes & Yes & Yes & Yes & Yes \\
\hline Noise controls & & & & Yes & Yes & Yes \\
\hline Additional control variables & & & & Yes & Yes & Yes \\
\hline \# Observations & 1,355 & 1,355 & 1,355 & 1,355 & 1,355 & 1,355 \\
\hline \# clusters (regions $\mathrm{x}$ industry) & 386 & 386 & 386 & 386 & 386 & 386 \\
\hline
\end{tabular}

Note: The table reports the estimates of the equation $Y_{\text {isrc }}=\alpha \cdot \exp _{\mathrm{s}} \cdot \mathrm{C}_{\mathrm{rc}}+X_{\mathrm{isc}} \beta+\lambda_{\mathrm{sc}}+\delta_{\mathrm{rc}}+\varepsilon_{\text {isrc }}$, with $\lambda_{\mathrm{sc}}$, manufacturing sector times country fixed effects, and $\delta_{\mathrm{rc}}$, regional fixed effects. $\operatorname{Exp}_{\mathrm{s}}$ is the measure of sensitivity to corruption computed using the US input-output table. $\mathrm{C}_{\mathrm{rc}}$ is our measure of corruption and $\mathrm{X}_{\mathrm{isc}}$ a set of control variables. We control for the US benchmarking bias by instrumenting the interaction term, exps. $\mathrm{C}_{\mathrm{rc}}$, using a full set of manufacturing sector dummies interacted with regional corruption.

1. Noise controls: interviewer characteristics (gender, a quadratic function in age, highest degree completed) and interview characteristics ( 7 dummies for the days of the week, 4 dummies for the time of the day - morning, lunch time, afternoon or evening -, the duration of the interview in minutes, and a quadratic trend in the date of the interview allowing for business cycle effects).

2. Additional control variables include a quadratic function of size (number of full-time employees), a dummy for unknown size, dummy variables by type of ownership, dummy variables by size of municipality and a dummy variable if the establishment is part of a larger firm.

Source: MOI survey, BEEPS 2009 and LITS 2006 (EBRD-WB), Nunn (2007), and authors' computations. 
Table 9. Difference-in-differences estimates instrumenting the share of sales paid as bribes by household assessment of regional corruption

\begin{tabular}{|c|c|c|c|c|c|c|}
\hline \multirow[t]{2}{*}{ Dependent variable: } & \multicolumn{6}{|c|}{ Average quality of management practices } \\
\hline & $(1)$ & $(2)$ & (3) & (4) & $(5)$ & (6) \\
\hline \multicolumn{7}{|c|}{ Panel A. Controlling for 10,22 and 59 manufacturing sectors } \\
\hline \multicolumn{7}{|c|}{ Share of sales paid as bribes } \\
\hline $\begin{array}{l}\text { x Contract dependence } \\
\text { (Nunn, 2007) }\end{array}$ & $\begin{array}{l}-1.831^{*} \\
(1.075)\end{array}$ & $\begin{array}{l}-1.985^{*} \\
(1.143)\end{array}$ & $\begin{array}{c}-3.026 * * \\
(1.321)\end{array}$ & $\begin{array}{c}-2.895 * * \\
(1.310)\end{array}$ & $\begin{array}{l}-2.084^{*} \\
(1.192)\end{array}$ & $\begin{array}{l}-2.288^{*} \\
(1.298)\end{array}$ \\
\hline F-test (First stage) & 1.704 & 0.829 & 0.981 & 0.863 & 3.036 & 1.800 \\
\hline Kleibergen-Paap & 13.44 & 9.967 & 18.26 & 16.81 & 49.45 & 43.64 \\
\hline Hansen J-statistics & 8.059 & 10.27 & 26.62 & 27.54 & 53.47 & 51.55 \\
\hline \multicolumn{7}{|l|}{ Panel B. Adding regional controls } \\
\hline $\begin{array}{l}\text { Share of sales paid as bribes } \\
\text { x Contract dependence } \\
\text { (Nunn, 2007) }\end{array}$ & $\begin{array}{l}-2.525^{*} \\
(1.306)\end{array}$ & $\begin{array}{l}-2.617^{*} \\
(1.381)\end{array}$ & $\begin{array}{c}-3.439 * * \\
(1.523)\end{array}$ & $\begin{array}{c}-3.186 * * \\
(1.487)\end{array}$ & $\begin{array}{c}-2.529^{* *} \\
(1.258)\end{array}$ & $\begin{array}{r}-2.274^{*} \\
(1.185)\end{array}$ \\
\hline Primary education or below & 3.079 & 2.836 & 0.483 & 0.771 & -1.075 & -1.608 \\
\hline x Contract dependence & $(2.509)$ & $(2.579)$ & $(3.690)$ & $(3.654)$ & $(2.960)$ & $(2.908)$ \\
\hline Unemployed or out of labor force & $-11.879 * *$ & $-11.459^{*}$ & $-18.243^{*}$ & $-17.161 *$ & -9.466 & -7.628 \\
\hline x Contract dependence & $(5.950)$ & $(6.123)$ & $(9.313)$ & $(9.254)$ & $(6.986)$ & $(6.909)$ \\
\hline Inter-individual trust & $1.508 *$ & $1.574^{*}$ & -1.878 & -1.935 & -0.706 & $-1.012^{*}$ \\
\hline x Contract dependence & $(0.797)$ & $(0.852)$ & $(1.184)$ & $(1.187)$ & $(0.540)$ & $(0.601)$ \\
\hline F-test (First stage) & 0.902 & 0.934 & 0.605 & 0.546 & 2.024 & 1.208 \\
\hline Kleibergen-Paap & 14.14 & 16.36 & 15.43 & 14.07 & 41.35 & 35.68 \\
\hline Hansen J-statistics & 7.795 & 8.087 & 23.09 & 23.99 & 50.45 & 50.36 \\
\hline 11 Industries $x$ country fixed effects & Yes & Yes & & & & \\
\hline 22 Industries $x$ country fixed effects & & & Yes & Yes & & \\
\hline 59 Industries $x$ country fixed effects & & & & & Yes & Yes \\
\hline Regional fixed effects & Yes & Yes & Yes & Yes & Yes & Yes \\
\hline Additional control variables & & Yes & & Yes & & Yes \\
\hline \# Observations & 1,355 & 1,355 & 1,355 & 1,355 & 1,355 & 1,355 \\
\hline \# clusters (regions $\mathrm{x}$ industry) & 386 & 386 & 386 & 386 & 386 & 386 \\
\hline
\end{tabular}

Note: The table reports the estimates of the equation $Y_{\text {isrc }}=\alpha \cdot \exp _{\mathrm{s}} . \mathrm{C}_{\mathrm{rc}}+\mathrm{X}_{\mathrm{isc}} \beta+\lambda_{\mathrm{sc}}+\delta_{\mathrm{rc}}+\varepsilon_{\text {isrc }}$, with $\lambda_{\mathrm{sc}}$, manufacturing sector times country fixed effects, and $\delta_{\mathrm{rc}}$, regional fixed effects. $\operatorname{Exp}_{\mathrm{s}}$ is the measure of sensitivity to corruption computed using the US input-output table. $\mathrm{C}_{\mathrm{rc}}$ is the regional share of sales paid as bribes and $\mathrm{X}_{\text {isrc }}$ a set of control variables. We control for the US benchmarking bias by instrumenting the interaction term, exps. $\mathrm{C}_{\mathrm{rc}}$, using a full set of manufacturing sector dummies interacted with household assessment of corruption.

1. Noise controls: interviewer characteristics (gender, a quadratic function in age, highest degree completed) and interview characteristics ( 7 dummies for the days of the week, 4 dummies for the time of the day - morning, lunch time, afternoon or evening -, the duration of the interview in minutes, and a quadratic trend in the date of the interview allowing for business cycle effects).

2. Additional control variables include a quadratic function of size (number of full-time employees), a dummy for unknown size, dummy variables by type of ownership, dummy variables by size of municipality and a dummy variable if the establishment is part of a larger firm.

Source: MOI survey, BEEPS 2009 and LITS 2006 (EBRD-WB), Nunn (2007), and authors' computations. 


\section{Table 10. Variation in the difference-in-differences estimates of the effect of corruption across sub-samples}

\begin{tabular}{|c|c|c|c|c|c|c|}
\hline \multirow[t]{3}{*}{ Dependent variable: } & \multicolumn{6}{|c|}{ Average quality of management practices } \\
\hline & \multicolumn{2}{|c|}{ Full sample } & \multicolumn{2}{|c|}{$\begin{array}{l}\text { BEEPS firms in the } \\
\text { region }>19\end{array}$} & \multicolumn{2}{|c|}{$\begin{array}{l}\text { BEEPS firms in the } \\
\text { region }>49\end{array}$} \\
\hline & $\begin{array}{l}\text { OLS } \\
(1)\end{array}$ & $\begin{array}{l}2 S L S \\
(2)\end{array}$ & $\begin{array}{l}0 \mathrm{LS} \\
(3)\end{array}$ & $\begin{array}{c}\text { 2SLS } \\
(4)\end{array}$ & $\begin{array}{l}\text { OLS } \\
(5)\end{array}$ & $\begin{array}{c}\text { 2SLS } \\
(6)\end{array}$ \\
\hline \multicolumn{7}{|c|}{ Controlling for 22 manufacturing sectors } \\
\hline $\begin{array}{l}\text { Share of sales paid as bribes } \\
\text { x Contract dependence } \\
\text { (Nunn, 2007) }\end{array}$ & $\begin{array}{l}-0.464 * \\
(0.271)\end{array}$ & $\begin{array}{c}-3.014^{* *} \\
(1.366)\end{array}$ & $\begin{array}{l}-0.493^{*} \\
(0.273)\end{array}$ & $\begin{array}{c}-2.825^{* *} \\
(1.279)\end{array}$ & $\begin{array}{l}-0.395 \\
(0.272)\end{array}$ & $\begin{array}{c}-2.938 * * \\
(1.473)\end{array}$ \\
\hline F-test (First stage) & & 1.368 & & 0.850 & & 0.976 \\
\hline Kleibergen-Paap & & 16.99 & & 16.41 & & 19.63 \\
\hline Hansen J-statistics & & 22.27 & & 30.12 & & 29.06 \\
\hline 22 Industries $x$ country fixed effects & Yes & Yes & Yes & Yes & Yes & Yes \\
\hline Regional fixed effects & Yes & Yes & Yes & Yes & Yes & Yes \\
\hline Additional control variables & Yes & Yes & Yes & Yes & Yes & Yes \\
\hline \# Observations & 1,355 & 1,355 & 1,331 & 1,331 & 1,112 & 1,112 \\
\hline \# clusters (regions x industry) & 386 & 386 & 373 & 373 & 292 & 292 \\
\hline
\end{tabular}

Note: The table reports the estimates of the equation $Y_{\text {isrc }}=\alpha \cdot \exp _{\mathrm{s}} \cdot \mathrm{C}_{\mathrm{rc}}+\mathrm{X}_{\mathrm{isr}} \beta+\lambda_{\mathrm{sc}}+\delta_{\mathrm{rc}}+\varepsilon_{\mathrm{iscc}}$, with $\lambda_{\mathrm{sc}}$, manufacturing sector times country fixed effects, and $\delta_{\mathrm{rc}}$, regional fixed effects. $\operatorname{Exp}_{\mathrm{s}}$ is the measure of sensitivity to corruption computed using the US input-output table. $\mathrm{C}_{\mathrm{rc}}$ is the regional share of sales paid as bribes and $\mathrm{X}_{\text {isrc }}$ a set of control variables. We control for the US benchmarking bias by instrumenting the interaction term, exps. $\mathrm{C}_{\mathrm{rc}}$, using a full set of manufacturing sector dummies interacted with household assessment of corruption.

1. Noise controls: interviewer characteristics (gender, a quadratic function in age, highest degree completed) and interview characteristics ( 7 dummies for the days of the week, 4 dummies for the time of the day - morning, lunch time, afternoon or evening -, the duration of the interview in minutes, and a quadratic trend in the date of the interview allowing for business cycle effects).

2. Additional control variables include a quadratic function of size (number of full-time employees), a dummy for unknown size, dummy variables by type of ownership, dummy variables by size of municipality and a dummy variable if the establishment is part of a larger firm.

Source: MOI survey, BEEPS 2009 and LITS 2006 (EBRD-WB), Nunn (2007), and authors' computations. 
Table 11. Variation in the difference-in-differences estimates of the effect of corruption across different firms

\begin{tabular}{|c|c|c|c|c|c|c|}
\hline \multirow[t]{3}{*}{ Dependent variable: } & \multicolumn{6}{|c|}{ Average quality of management practices } \\
\hline & \multicolumn{2}{|c|}{$\begin{array}{l}\text { Foreign owned } \\
\text { establishments }\end{array}$} & \multicolumn{2}{|c|}{$\begin{array}{l}\text { Large establishments } \\
>249 \text { employees }\end{array}$} & \multicolumn{2}{|c|}{$\begin{array}{c}\text { State owned } \\
\text { establishments }\end{array}$} \\
\hline & $\begin{array}{l}0 \text { LS } \\
(1)\end{array}$ & $\begin{array}{c}2 S L S \\
(2)\end{array}$ & $\begin{array}{c}0 \mathrm{LS} \\
(3)\end{array}$ & $\begin{array}{c}\text { 2SLS } \\
(4)\end{array}$ & $\begin{array}{l}0 \text { LS } \\
(5)\end{array}$ & $\begin{array}{c}2 S L S \\
(6)\end{array}$ \\
\hline \multicolumn{7}{|c|}{ Controlling for 22 manufacturing sectors } \\
\hline Share of sales paid as bribes & & & & & & \\
\hline x Contract dependence & $-0.591 *$ & $-3.719^{*}$ & $-0.578^{*}$ & $-2.876^{*}$ & $-0.616^{* *}$ & $-3.334 *$ \\
\hline $\begin{array}{l}\text { (Nunn, 2007) } \\
x \text {........ x Foreign owned }\end{array}$ & $(0.311)$ & $(1.970)$ & & & & \\
\hline x ......... x Foreign owned & $\begin{array}{l}-0.051 \\
(0.085)\end{array}$ & $\begin{array}{c}0.245 \\
(0.347)\end{array}$ & & & & \\
\hline $\mathrm{x} \ldots \ldots \ldots \mathrm{x}$ Large firm & & & $\begin{array}{l}-0.108 \\
(0.095)\end{array}$ & $\begin{array}{l}-0.083 \\
(0.203)\end{array}$ & & \\
\hline $\mathrm{x} \ldots \ldots \ldots \mathrm{x}$ State owned & & & & & $\begin{array}{l}-0.050 \\
(0.163)\end{array}$ & $\begin{array}{c}0.210 \\
(0.461)\end{array}$ \\
\hline Foreign owned establishment & $\begin{array}{c}0.205 \\
(0.131)\end{array}$ & $\begin{array}{l}-0.050 \\
(0.287)\end{array}$ & & & & \\
\hline $\begin{array}{l}\text { Large establishment } \\
\text { (>249 employees) }\end{array}$ & & & $\begin{array}{c}0.302^{* * *} \\
(0.109)\end{array}$ & $\begin{array}{l}0.275^{*} \\
(0.157)\end{array}$ & & \\
\hline State owned establishment & & & & & $\begin{array}{l}-0.033 \\
(0.207)\end{array}$ & $\begin{array}{l}-0.335 \\
(0.450)\end{array}$ \\
\hline F-test (First stage) & & 1.013 & & 1.044 & & 0.782 \\
\hline Kleibergen-Paap & & 25.87 & & 27.99 & & 29.86 \\
\hline Hansen J-statistics & & 41.88 & & 49.92 & & 43.64 \\
\hline 22 Industries $x$ country fixed effects & Yes & Yes & Yes & Yes & Yes & Yes \\
\hline Regional fixed effects & Yes & Yes & Yes & Yes & Yes & Yes \\
\hline Additional control variables & Yes & Yes & Yes & Yes & Yes & Yes \\
\hline \# Observations & 1,355 & 1,355 & 1,355 & 1,355 & 1,355 & 1,355 \\
\hline \# clusters (regions $\mathrm{x}$ industry) & 386 & 386 & 386 & 386 & 386 & 386 \\
\hline
\end{tabular}

Note: The table reports the estimates of the equation $Y_{\text {isrc }}=\alpha \cdot \exp _{\mathrm{s}} \cdot \mathrm{C}_{\mathrm{rc}}+\mathrm{X}_{\mathrm{isc}} \beta+\lambda_{\mathrm{sc}}+\delta_{\mathrm{rc}}+\varepsilon_{\text {iscc }}$, with $\lambda_{\mathrm{sc}}$, manufacturing sector times country fixed effects, and $\delta_{\mathrm{rc}}$, regional fixed effects. $\operatorname{Exp}_{\mathrm{s}}$ is the measure of sensitivity to corruption computed using the US input-output table. $\mathrm{C}_{\mathrm{rc}}$ is the regional share of sales paid as bribes and $\mathrm{X}_{\text {isrc }}$ a set of control variables. We control for the US benchmarking bias by instrumenting the interaction term, exps. $\mathrm{C}_{\mathrm{rc}}$, using a full set of manufacturing sector dummies interacted with household assessment of corruption.

1. Noise controls: interviewer characteristics (gender, a quadratic function in age, highest degree completed) and interview characteristics ( 7 dummies for the days of the week, 4 dummies for the time of the day - morning, lunch time, afternoon or evening -, the duration of the interview in minutes, and a quadratic trend in the date of the interview allowing for business cycle effects).

2. Additional control variables include a quadratic function of size (number of full-time employees), a dummy for unknown size, dummy variables by type of ownership, dummy variables by size of municipality and a dummy variable if the establishment is part of a larger firm.

Source: MOI survey, BEEPS 2009 and LITS 2006 (EBRD-WB), Nunn (2007), and authors' computations. 
Table 12. Corruption and different forms of management practices

\begin{tabular}{|c|c|c|c|c|c|c|}
\hline \multirow[t]{3}{*}{ Dependent variable: } & \multicolumn{6}{|c|}{ Average quality of management practices } \\
\hline & \multirow[b]{2}{*}{$\begin{array}{c}\text { Monitoring } \\
\text { (1) }\end{array}$} & \multirow[b]{2}{*}{$\begin{array}{c}\text { No target } \\
\text { (2) }\end{array}$} & \multirow[b]{2}{*}{$\begin{array}{c}\text { Incentives } \\
(3)\end{array}$} & \multirow[b]{2}{*}{$\begin{array}{l}\text { Turn- } \\
\text { over } \\
\text { (4) }\end{array}$} & \multicolumn{2}{|c|}{ Share of college graduates } \\
\hline & & & & & $\begin{array}{l}\text { Production } \\
\text { workers } \\
\text { (5) }\end{array}$ & $\begin{array}{c}\text { Administrative } \\
\text { workers } \\
\text { (6) }\end{array}$ \\
\hline \multicolumn{7}{|c|}{ Panel A. Controlling for 11 manufacturing sectors $0 \mathrm{LS}$} \\
\hline $\begin{array}{l}\text { Frequency of bribes } \\
\text { (LITS 2006) }\end{array}$ & $\begin{array}{l}-1.057 * * * \\
(0.091)\end{array}$ & $\begin{array}{l}-0.011 \\
(0.019)\end{array}$ & $\begin{array}{c}-0.224^{* *} \\
(0.099)\end{array}$ & $\begin{array}{c}0.141 \\
(1.603)\end{array}$ & $\begin{array}{c}0.087 * * * \\
(0.029)\end{array}$ & $\begin{array}{c}0.061 \\
(0.037)\end{array}$ \\
\hline R-square & 0.237 & 0.114 & 0.180 & 0.126 & 0.244 & 0.259 \\
\hline \# Observations & 1354 & 1336 & 1354 & 1214 & 1201 & 1227 \\
\hline \# clusters (regions) & 56 & 56 & 56 & 56 & 56 & 56 \\
\hline \multicolumn{7}{|c|}{ Panel B. Controlling for 11 manufacturing sectors DID OLS } \\
\hline $\begin{array}{l}\text { Frequency of bribes } \\
\quad \text { x Contract dependence }\end{array}$ & $\begin{array}{c}-1.876^{* *} \\
(0.866)\end{array}$ & $\begin{array}{c}0.289 * * * \\
(0.092)\end{array}$ & $\begin{array}{l}-0.336 \\
(0.542)\end{array}$ & $\begin{array}{l}9.764 * \\
(5.682)\end{array}$ & $\begin{array}{l}-0.186 \\
(0.136)\end{array}$ & $\begin{array}{c}-0.378 * * \\
(0.186)\end{array}$ \\
\hline R-square & 0.241 & 0.193 & 0.180 & 0.174 & 0.294 & 0.317 \\
\hline \# Observations & 1354 & 1336 & 1354 & 1214 & 1201 & 1227 \\
\hline \# clusters (regions x industry) & 386 & 386 & 387 & 369 & 367 & 370 \\
\hline \multicolumn{7}{|c|}{ Panel C. Controlling for 11 manufacturing sectors DID-IV } \\
\hline $\begin{array}{l}\text { Frequency of bribes } \\
\text { x Contract dependence }\end{array}$ & $\begin{array}{l}-1.862 * * * \\
(0.696)\end{array}$ & $\begin{array}{l}0.303 * * * \\
(0.087)\end{array}$ & $\begin{array}{l}-0.266 \\
(0.479)\end{array}$ & $\begin{array}{c}8.229 \\
(5.014)\end{array}$ & $\begin{array}{l}-0.179 \\
(0.113)\end{array}$ & $\begin{array}{c}-0.367 * * \\
(0.153)\end{array}$ \\
\hline F-test (First stage) & 92.16 & 59.97 & 89.40 & 99.86 & 103.5 & 86.39 \\
\hline Kleibergen-Paap & 37.36 & 32.47 & 36.09 & 30.85 & 33.14 & 34.23 \\
\hline Hansen J-statistics & 10.61 & 13.65 & 10.82 & 3.378 & 16.45 & 13.25 \\
\hline Industry $x$ country fixed effects & Yes & Yes & Yes & Yes & Yes & Yes \\
\hline Regional fixed effects & Yes & Yes & Yes & Yes & Yes & Yes \\
\hline Noise controls & Yes & Yes & Yes & Yes & Yes & Yes \\
\hline Additional control variables & Yes & Yes & Yes & Yes & Yes & Yes \\
\hline \# Observations & 1354 & 1336 & 1354 & 1214 & 1201 & 1227 \\
\hline \# clusters (regions x industry) & 386 & 386 & 387 & 369 & 367 & 370 \\
\hline
\end{tabular}

Note: The table reports the estimates of the equation $Y_{\text {isrc }}=\alpha \cdot \exp _{\mathrm{s}} \cdot \mathrm{C}_{\mathrm{rc}}+X_{\mathrm{isc}} \beta+\lambda_{\mathrm{sc}}+\delta_{\mathrm{rc}}+\varepsilon_{\text {isrc }}$, with $\lambda_{\mathrm{sc}}$, manufacturing sector times country fixed effects, and $\delta_{\mathrm{rc}}$, regional fixed effects. $\operatorname{Exp}_{\mathrm{s}}$ is the measure of sensitivity to corruption computed using the US input-output table. $\mathrm{C}_{\mathrm{rc}}$ is our measure of corruption and $\mathrm{X}_{\mathrm{isc}}$ a set of control variables. We control for the US benchmarking bias by instrumenting the interaction term, exps. $\mathrm{C}_{\mathrm{rc}}$, using a full set of manufacturing sector dummies interacted with regional corruption.

1. Noise controls: interviewer characteristics (gender, a quadratic function in age, highest degree completed) and interview characteristics ( 7 dummies for the days of the week, 4 dummies for the time of the day - morning, lunch time, afternoon or evening -, the duration of the interview in minutes, and a quadratic trend in the date of the interview allowing for business cycle effects).

2. Additional control variables include a quadratic function of size (number of full-time employees), a dummy for unknown size, dummy variables by type of ownership, dummy variables by size of municipality and a dummy variable if the establishment is part of a larger firm.

Source: MOI survey, BEEPS 2009 and LITS 2006 (EBRD-WB), Nunn (2007), and authors' computations. 
Table 13. Corruption and different forms of management practices

\begin{tabular}{|c|c|c|c|c|c|c|}
\hline & \multirow{2}{*}{$\begin{array}{l}\text { Oper } \\
\text { ations } \\
(1)\end{array}$} & \multirow{2}{*}{$\begin{array}{l}\text { Central- } \\
\text { ization } \\
\text { (2) }\end{array}$} & \multirow[b]{2}{*}{$\begin{array}{c}\text { Innovation } \\
\text { (3) }\end{array}$} & \multirow{2}{*}{$\begin{array}{c}\text { R\&D } \\
\text { spending } \\
(4)\end{array}$} & \multicolumn{2}{|c|}{ Main market } \\
\hline & & & & & $\begin{array}{l}\text { Regional } \\
\text { (5) }\end{array}$ & $\begin{array}{c}\text { International } \\
(6)\end{array}$ \\
\hline \multicolumn{7}{|c|}{ Panel A. Controlling for 11 manufacturing sectors OLS } \\
\hline $\begin{array}{l}\text { Frequency of bribes } \\
\text { (LITS 2006) } \\
\text { R-square }\end{array}$ & $\begin{array}{c}-0.004 \\
(0.040) \\
0.233\end{array}$ & $\begin{array}{c}-0.066 * * * \\
(0.024) \\
0.163\end{array}$ & $\begin{array}{l}0.030 \\
(0.045)\end{array}$ & $\begin{array}{l}-0.021 \\
(0.039)\end{array}$ & $\begin{array}{l}-0.036 \\
(0.055)\end{array}$ & $\begin{array}{c}0.011 \\
(0.035)\end{array}$ \\
\hline R-square & 0.233 & 0.163 & 0.184 & 0.219 & 0.209 & 0.369 \\
\hline \# Observations & 1354 & 1355 & 1348 & 1320 & 1343 & 1343 \\
\hline \# clusters (regions) & 56 & 56 & 56 & 56 & 56 & 56 \\
\hline \multicolumn{7}{|c|}{ Panel B. Controlling for 11 manufacturing sectors DID OLS } \\
\hline $\begin{array}{l}\text { Frequency of bribes } \\
\quad \text { x Contract dependence }\end{array}$ & $\begin{array}{c}-1.101 * * * \\
(0.199)\end{array}$ & $\begin{array}{c}0.317 * * \\
(0.135)\end{array}$ & $\begin{array}{c}-0.843 * * * \\
(0.232)\end{array}$ & $\begin{array}{l}-0.735 * * * \\
(0.253)\end{array}$ & $\begin{array}{l}0.919 * * * \\
(0.237)\end{array}$ & $\begin{array}{l}-0.945^{* * *} \\
(0.184)\end{array}$ \\
\hline R-square & 0.212 & 0.246 & 0.234 & 0.254 & 0.263 & 0.408 \\
\hline \# Observations & 1351 & 1355 & 1348 & 1320 & 1343 & 1343 \\
\hline \# clusters (regions $\mathrm{x}$ industry) & 385 & 386 & 385 & 382 & 385 & 385 \\
\hline \multicolumn{7}{|c|}{ Panel C. Controlling for 11 manufacturing sectors DID-IV } \\
\hline $\begin{array}{l}\text { Frequency of bribes } \\
\quad \text { x Contract dependence }\end{array}$ & $\begin{array}{l}-0.679 \\
(0.553)\end{array}$ & $\begin{array}{r}0.263^{* *} \\
(0.114)\end{array}$ & $\begin{array}{l}-0.787 * * * \\
(0.195)\end{array}$ & $\begin{array}{l}-0.655^{* * *} \\
(0.229)\end{array}$ & $\begin{array}{l}0.859^{* * *} \\
(0.202)\end{array}$ & $\begin{array}{l}-0.863^{* * *} \\
(0.150)\end{array}$ \\
\hline F-test (First stage) & 89.79 & 92.13 & 93.10 & 96.28 & 90.26 & 90.26 \\
\hline Kleibergen-Paap & 36.20 & 37.36 & 37.83 & 36.02 & 36.38 & 36.38 \\
\hline Hansen J-statistics & 10.61 & 19.93 & 8.12 & 7.85 & 8.77 & 11.55 \\
\hline Industry $\mathrm{x}$ country fixed effects & Yes & Yes & Yes & Yes & Yes & Yes \\
\hline Regional fixed effects & Yes & Yes & Yes & Yes & Yes & Yes \\
\hline Noise controls & Yes & Yes & Yes & Yes & Yes & Yes \\
\hline Additional control variables & Yes & Yes & Yes & Yes & Yes & Yes \\
\hline \# Observations & 1351 & 1355 & 1348 & 1320 & 1343 & 1343 \\
\hline \# clusters (regions $\mathrm{x}$ industry) & 385 & 386 & 385 & 382 & 385 & 385 \\
\hline
\end{tabular}

Note: The table reports the estimates of the equation $\mathrm{Y}_{\text {isrc }}=\alpha \cdot \exp _{\mathrm{s}} \cdot \mathrm{C}_{\mathrm{rc}}+\mathrm{X}_{\mathrm{isc}} \beta+\lambda_{\mathrm{sc}}+\delta_{\mathrm{rc}}+\varepsilon_{\text {isrc }}$, with $\lambda_{\mathrm{sc}}$, manufacturing sector times country fixed effects, and $\delta_{\text {rc }}$, regional fixed effects. $\operatorname{Exp}_{\mathrm{s}}$ is the measure of sensitivity to corruption computed using the US input-output table. $\mathrm{C}_{\mathrm{rc}}$ is our measure of corruption and $\mathrm{X}_{\mathrm{isrc}}$ a set of control variables. We control for the US benchmarking bias by instrumenting the interaction term, exps. $\mathrm{C}_{\mathrm{rc}}$, using a full set of manufacturing sector dummies interacted with regional corruption.

1. Noise controls: interviewer characteristics (gender, a quadratic function in age, highest degree completed) and interview characteristics ( 7 dummies for the days of the week, 4 dummies for the time of the day - morning, lunch time, afternoon or evening -, the duration of the interview in minutes, and a quadratic trend in the date of the interview allowing for business cycle effects).

2. Additional control variables include a quadratic function of size (number of full-time employees), a dummy for unknown size, dummy variables by type of ownership, dummy variables by size of municipality and a dummy variable if the establishment is part of a larger firm.

Source: MOI survey, BEEPS 2009 and LITS 2006 (EBRD-WB), Nunn (2007), and authors' computations. 
Appendix.

Figure A.1. Corruption by country and regional dispersion

\section{A.1..a. Firm share of sales paid as bribes}

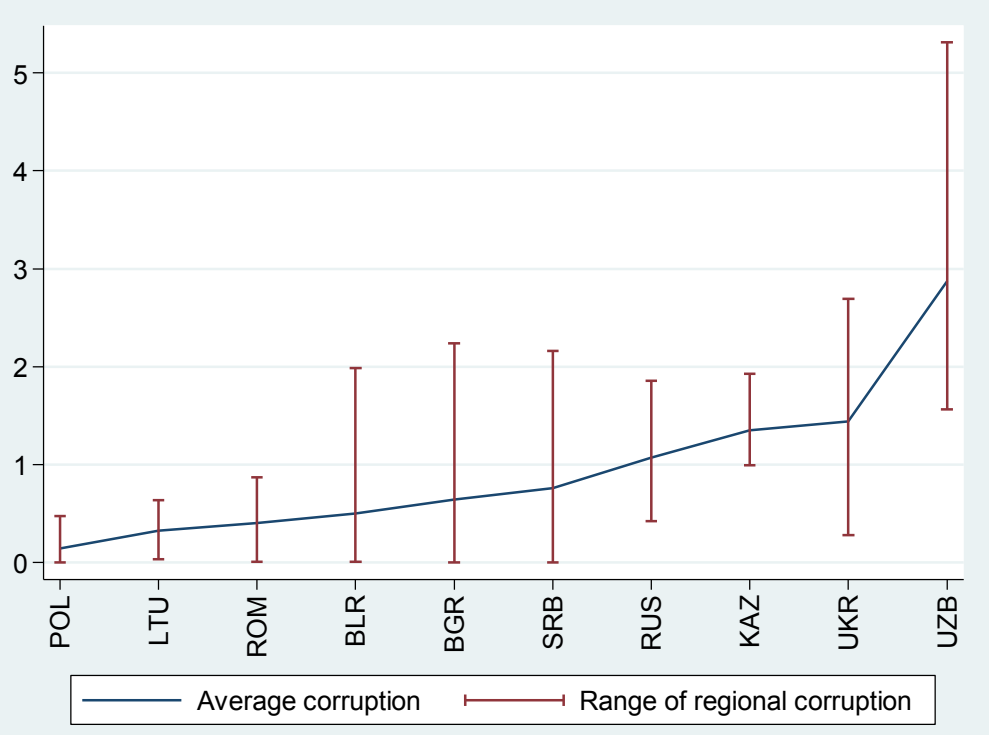

\section{A.1.b. Household assessment of the frequency of corruption}

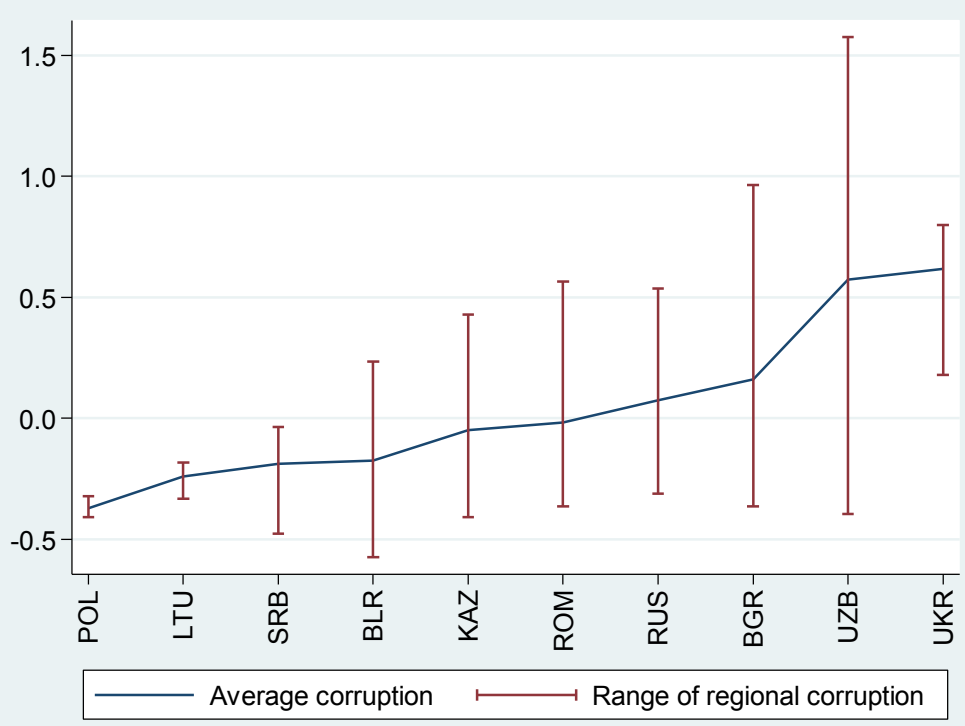

Note: The graphs show regional levels of corruption. The solid line represents the un-weighted-country average of regional measures of corruption. The vertical bars denote minimum and maximum levels. BGR stands for Bulgaria, BLR for Belarus, KAZ for Kazakstan, LTU for Lithuania, POL for Poland, ROM for Romania, RUS for Russia, SER for Serbia, UKR for Ukraine, and UZB for Uzbekistan.

Source: BEEPS 2009, LITS 2006 (EBRD-WB), and authors' computations. 
Table A.1. Contract dependence by manufacturing sectors

\begin{tabular}{lc}
\hline 10 manufacturing sectors, less dependent of contracts & $\begin{array}{c}\text { Contract } \\
\text { dependence }\end{array}$ \\
\hline Manufacture of malt liquors and malt & 0.11 \\
Manufacture of grain mill products & 0.38 \\
Manufacture of vegetable and animal oils and fats & 0.47 \\
Production, processing and preserving of meat and meat products & 0.52 \\
Manufacture of prepared animal feeds & 0.59 \\
Manufacture of tobacco products & 0.60 \\
Manufacture of basic precious and non-ferrous metals & 0.60 \\
Processing and preserving of fruit and vegetables & 0.60 \\
Manufacture of dairy products & 0.64 \\
Manufacture of veneer sheets; manufacture of plywood, & 0.65 \\
laminboard, particle board and other panels and boards & \\
\hline 10 manufacturing sectors, more dependent of contracts & 0.99 \\
\hline Manufacture of industrial process control equipment & 0.99 \\
Manufacture of jewellery and related articles & 0.99 \\
Manufacture of office, accounting and computing machinery & 0.99 \\
Manufacture of television and radio transmitters and apparatus & 1.00 \\
for line telephony and line telegraphy & 1.00 \\
Service activities related to printing & 1.00 \\
Publishing of newspapers, journals and periodicals & 1.00 \\
Other publishing & 1.00 \\
Printing & 1.00 \\
Manufacture of macaroni, noodles, couscous and similar farinaceous & \\
products & \\
Reproduction of recorded media & \\
\hline
\end{tabular}

Note: Contract dependence of manufacturing sectors at the ISIC3.1 4 digits level. The measure is the share of relationship-specific inputs used by each US manufacturing sector in 1997. It is computed using Nunn (2007) share of inputs neither traded on open markets nor listed on leaflets at the 6-digit I-O classification level. It is converted to ISIC3.1 sectors using the BEA correspondence between the I-O classification and the NAICS 1997 and the BLS correspondence files between NAICS 1997 and 2002 and NAICS 2002 and ISIC3.1.

Source: Nunn (2007), Rauch (1999) and authors' computations. 
Table A.2. Product complexity by manufacturing sectors

\begin{tabular}{lc}
\hline 10 manufacturing sectors, with less complex product & $\begin{array}{c}\text { (minus) } \\
\text { Herfindahl }\end{array}$ \\
\hline Manufacture of malt liquors and malt & -0.24 \\
Manufacture of vegetable and animal oils and fats & -0.21 \\
Manufacture of pumps, compressors, taps and valves & -0.20 \\
Manufacture of tobacco products & -0.19 \\
Processing and preserving of fish and fish products & -0.18 \\
Publishing of newspapers, journals and periodicals & -0.18 \\
Tanning and dressing of leather & -0.18 \\
Manufacture of steam generators, except central heating hot water boilers & -0.17 \\
Manufacture of dairy products & -0.17 \\
Other publishing & -0.17 \\
\hline 10 manufacturing sectors, with more complex product & \\
\hline Manufacture of soap and detergents, cleaning and polishing preparations, & -0.06 \\
perfumes and toilet preparations & -0.06 \\
Manufacture of fertilizers and nitrogen compounds & -0.06 \\
Manufacture of parts and accessories for motor vehicles and their engines & -0.05 \\
Manufacture of other general-purpose machinery & -0.05 \\
Recycling of non-metal waste and scrap & -0.05 \\
Manufacture of other fabricated metal products n.e.c. & -0.05 \\
Manufacture of other non-metallic mineral products n.e.c. & -0.05 \\
Manufacture of basic precious and non-ferrous metals & -0.04 \\
Manufacture of other textiles n.e.c. & -0.04 \\
Manufacture of motor vehicles &
\end{tabular}

Note: Product complexity is_(minus the) Herfindahl index computed from the BEA 1997 benchmark use table by industry at the 6-digits I-O level. It is converted to ISIC3.1 sectors using the BEA correspondence between the I-O classification and the NAICS 1997 and the BLS correspondence files between NAICS 1997 and 2002 and NAICS 2002 and ISIC3.1. The presented index is minus the usual Herfindahl index and higher values indicate sectors with lower input concentration.

Source: BEA 1997 benchmark use table by industry and authors' computations. 
Table A.3. Correlations between different metrics of institutional dependence by manufacturing sectors

\begin{tabular}{|c|c|c|c|c|c|c|c|}
\hline & \multicolumn{4}{|c|}{ Contract dependence } & \multicolumn{3}{|c|}{ Concentration of inputs } \\
\hline & \multicolumn{2}{|c|}{$\begin{array}{l}\text { Share of inputs neither } \\
\text { sold on exchange } \\
\text { markets nor having } \\
\text { listed prices }\end{array}$} & \multicolumn{2}{|c|}{$\begin{array}{l}\text { Share of inputs } \\
\text { not sold on } \\
\text { exchange markets }\end{array}$} & \multirow[t]{2}{*}{$\begin{array}{l}\text { Herfindahl } \\
\text { (minus) }\end{array}$} & \multirow[t]{2}{*}{$\begin{array}{c}\text { Gini } \\
\text { (minus) }\end{array}$} & \multirow[t]{2}{*}{$\begin{array}{l}\text { Share } \\
20 \\
\text { (minus) }\end{array}$} \\
\hline & (lib) & (cons) & (lib) & (cons) & & & \\
\hline \multicolumn{8}{|c|}{ Panel A. Linear correlations between metrics of institutional dependence } \\
\hline Contract dependence (lib) & 1.00 & & & & & & \\
\hline Contract dependence (cons) & 0.93 & 1.00 & & & & & \\
\hline $\begin{array}{l}\text { Contract dependence based } \\
\text { on exchange (lib) }\end{array}$ & 0.62 & 0.59 & 1.00 & & & & \\
\hline $\begin{array}{l}\text { Contract dependence based } \\
\text { on exchange (cons) }\end{array}$ & 0.66 & 0.62 & 0.95 & 1.00 & & & \\
\hline (minus) Herfindahl index & 0.29 & 0.29 & 0.14 & 0.19 & 1.00 & & \\
\hline (minus) Gini index & 0.33 & 0.33 & 0.29 & 0.35 & 0.69 & 1.00 & \\
\hline $\begin{array}{l}\text { (minus) Shareof the } 20 \\
\text { most important inputs }\end{array}$ & 0.38 & 0.37 & 0.32 & 0.38 & 0.70 & 0.98 & 1.00 \\
\hline \multicolumn{8}{|c|}{ Panel B. Non-linear correlations between metrics of institutional dependence } \\
\hline Contract dependence (lib) & 1.00 & & & & & & \\
\hline Contract dependence (cons) & 0.86 & 1.00 & & & & & \\
\hline $\begin{array}{l}\text { Contract dependence based } \\
\text { on exchange (lib) }\end{array}$ & 0.62 & 0.58 & 1.00 & & & & \\
\hline $\begin{array}{l}\text { Contract dependence based } \\
\text { on exchange (cons) }\end{array}$ & 0.64 & 0.56 & 0.95 & 1.00 & & & \\
\hline (minus) Herfindahl index & -0.03 & -0.07 & 0.10 & 0.17 & 1.00 & & \\
\hline (minus) Gini index & 0.17 & 0.13 & 0.31 & 0.39 & 0.72 & 1.00 & \\
\hline $\begin{array}{l}\text { (minus) Shareof the } 20 \\
\text { most important inputs }\end{array}$ & 0.18 & 0.14 & 0.32 & 0.40 & 0.69 & 0.99 & 1.00 \\
\hline \# Manufacturing sectors & 126 & 126 & 126 & 126 & 126 & 126 & 126 \\
\hline
\end{tabular}

Note: Contract dependence of manufacturing sectors at the ISIC3.1 4 digits level. The measure is the share of relationship-specific inputs used by each US manufacturing sector in 1997. It is computed using Nunn (2007) share of inputs neither traded on open markets nor listed on leaflets at the 6-digit I-O classification level. (Minus the) Herfindahl index, (minus the) Gini index, (minus the) share of the 20 most important inputs computed from the BEA 1997 benchmark use table by industry at the 6-digits I-O level. All measures are converted to ISIC3.1 sectors using the BEA correspondence between the I-O classification and the NAICS 1997 and the BLS correspondence files between NAICS 1997 and 2002 and NAICS 2002 and ISIC3.1.

Source: Nunn (2007), Rauch (1999) and authors' computations. 
Table A.4. Difference-in-differences estimate using the index of product complexity (minus the Herfindahl index of inputs)

\begin{tabular}{|c|c|c|c|c|c|c|}
\hline \multirow[t]{2}{*}{ Dependent variable: } & \multicolumn{6}{|c|}{ Average quality of management practices } \\
\hline & (1) & (2) & (3) & (4) & (5) & (6) \\
\hline \multicolumn{7}{|c|}{ Panel A. Controlling for 10 manufacturing sectors } \\
\hline Frequency of bribes (BEEPS 2009) & -7.953 & & & -7.531 & & \\
\hline $\mathrm{x}$ Product complexity & $(6.605)$ & & & $(7.036)$ & & \\
\hline Frequency of bribes (LITS 2006) & & $-9.046 * * *$ & & & $-9.752 * * *$ & \\
\hline $\begin{array}{l}\text { x Product complexity } \\
\text { Share }\end{array}$ & & & & & & \\
\hline $\begin{array}{l}\text { Share of sales paid as bribes (BEEPS 2009) } \\
\text { x Product complexity }\end{array}$ & & & $\begin{array}{c}-5.627 * * * \\
(1.669)\end{array}$ & & & $\begin{array}{c}-5.634 * * * \\
(1.785)\end{array}$ \\
\hline R-square & 0.192 & 0.193 & 0.194 & 0.225 & 0.227 & 0.227 \\
\hline \multicolumn{7}{|c|}{ Panel B. Controlling for 22 manufacturing sectors } \\
\hline Frequency of bribes (BEEPS 2009) & -2.549 & & & $\begin{array}{l}-2.293 \\
(4.348)\end{array}$ & & \\
\hline Frequency of bribes (LITS 2006) & $(4.220)$ & $-6.347^{* *}$ & & & $-7.145 * *$ & \\
\hline $\mathrm{x}$ Product complexity & & $(2.804)$ & & & $(2.833)$ & \\
\hline $\begin{array}{l}\text { Share of sales paid as bribes (BEEPS 2009) } \\
\text { x Product complexity }\end{array}$ & & & $\begin{array}{c}-4.030 * * \\
(1.707)\end{array}$ & & & $\begin{array}{c}-4.200^{* *} \\
(1.857)\end{array}$ \\
\hline R-square & 0.244 & 0.245 & 0.245 & 0.273 & 0.275 & 0.275 \\
\hline \multicolumn{7}{|c|}{ Panel C. Controlling for 59 manufacturing sectors } \\
\hline $\begin{array}{l}\text { Frequency of bribes (BEEPS 2009) } \\
\quad \text { x Product complexity }\end{array}$ & $\begin{array}{l}-3.462 \\
(4.122)\end{array}$ & & & $\begin{array}{l}-4.802 \\
(4.175)\end{array}$ & & \\
\hline $\begin{array}{l}\text { Frequency of bribes (LITS 2006) } \\
\text { x Product complexity }\end{array}$ & & $\begin{array}{l}-4.403 \\
(2.934)\end{array}$ & & & $\begin{array}{l}-5.506^{*} \\
(2.951)\end{array}$ & \\
\hline $\begin{array}{l}\text { Share of sales paid as bribes (BEEPS 2009) } \\
\quad \text { x Product complexity }\end{array}$ & & & $\begin{array}{l}-1.907 \\
(2.179)\end{array}$ & & & $\begin{array}{l}-2.613 \\
(2.250)\end{array}$ \\
\hline R-square & 0.344 & 0.344 & 0.344 & 0.368 & 0.369 & 0.368 \\
\hline Industry $x$ country fixed effects & Yes & Yes & Yes & Yes & Yes & Yes \\
\hline Noise controls & & & & Yes & Yes & Yes \\
\hline Additional control variables & & & & Yes & Yes & Yes \\
\hline \# Observations & 1,355 & 1,355 & 1,355 & 1,355 & 1,355 & 1,355 \\
\hline \# clusters (regions x industry) & 386 & 386 & 386 & 386 & 386 & 386 \\
\hline
\end{tabular}

Note: The table reports the estimates of the equation $Y_{\text {isrc }}=\alpha \cdot \exp _{\mathrm{s}} \cdot \mathrm{C}_{\mathrm{rc}}+\mathrm{X}_{\mathrm{isc}} \beta+\lambda_{\mathrm{sc}}+\delta_{\mathrm{rc}}+\varepsilon_{\mathrm{isc}}$, with $\lambda_{\mathrm{sc}}$, manufacturing sector times country fixed effects, and $\delta_{\mathrm{rc}}$, regional fixed effects. $\operatorname{Exp}_{\mathrm{s}}$ is the measure of sensitivity to corruption computed using the US input-output table. $\mathrm{C}_{\mathrm{rc}}$ is our measure of corruption and $\mathrm{X}_{\mathrm{iscc}}$ a set of control variables.

1. Noise controls include interviewer characteristics (gender, a quadratic in age, highest degree) and interview characteristics. The later include 7 dummies for the days of the week, 4 dummies for the time of the day (morning, lunch time, afternoon or evening), the duration of the interview (in minutes), and a quadratic trend in the date of the interview allowing for business cycle effects.

2. Additional control variables include a quadratic function of size (number of full-time employees), a dummy for unknown size, dummy variables by types of ownership, dummy variables by size of municipality and a dummy variable if the establishment is part of a larger firm.

Source: MOI survey, BEEPS 2009 and LITS 2006 (EBRD-WB), and authors' computations. 
Table A.5. Difference-in-differences estimate using the index of product complexity (minus the Herfindahl index of inputs) and correcting for US benchmarking bias

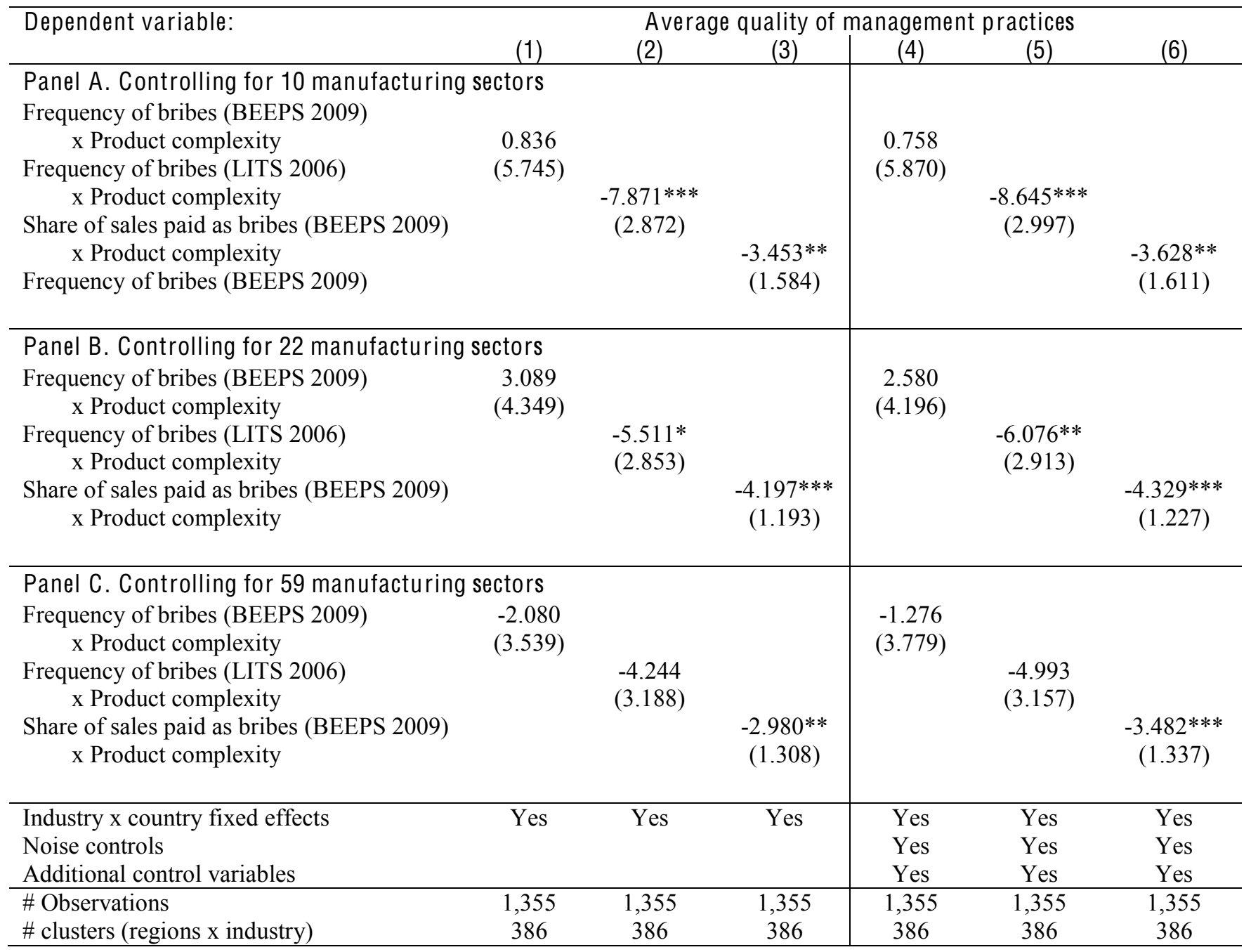

Note: The table reports the estimates of the equation $Y_{\text {isrc }}=\alpha \cdot \exp _{\mathrm{s}} . \mathrm{C}_{\mathrm{rc}}+X_{\mathrm{isc}} \beta+\lambda_{\mathrm{sc}}+\delta_{\mathrm{rc}}+\varepsilon_{\text {isrc }}$, with $\lambda_{\mathrm{sc}}$, manufacturing sector times country fixed effects, and $\delta_{\mathrm{rc}}$, regional fixed effects. $\operatorname{Exp}_{\mathrm{s}}$ is the measure of sensitivity to corruption computed using the US input-output table. $\mathrm{C}_{\mathrm{rc}}$ is our measure of corruption and $\mathrm{X}_{\mathrm{iscc}}$ a set of control variables. We control for the US benchmarking bias by instrumenting the interaction term, exps. $\mathrm{C}_{\mathrm{rc}}$, using a full set of manufacturing sector dummies interacted with regional corruption.

1. Noise controls include interviewer characteristics (gender, a quadratic in age, highest degree) and interview characteristics. The later include 7 dummies for the days of the week, 4 dummies for the time of the day (morning, lunch time, afternoon or evening), the duration of the interview (in minutes), and a quadratic trend in the date of the interview allowing for business cycle effects.

2. Additional control variables include a quadratic function of size (number of full-time employees), a dummy for unknown size, dummy variables by types of ownership, dummy variables by size of municipality and a dummy variable if the establishment is part of a larger firm.

Source: MOI survey, BEEPS 2009 and LITS 2006 (EBRD-WB), and authors' computations. 
Table A.6. Correlations between management practices

Quality of management practices

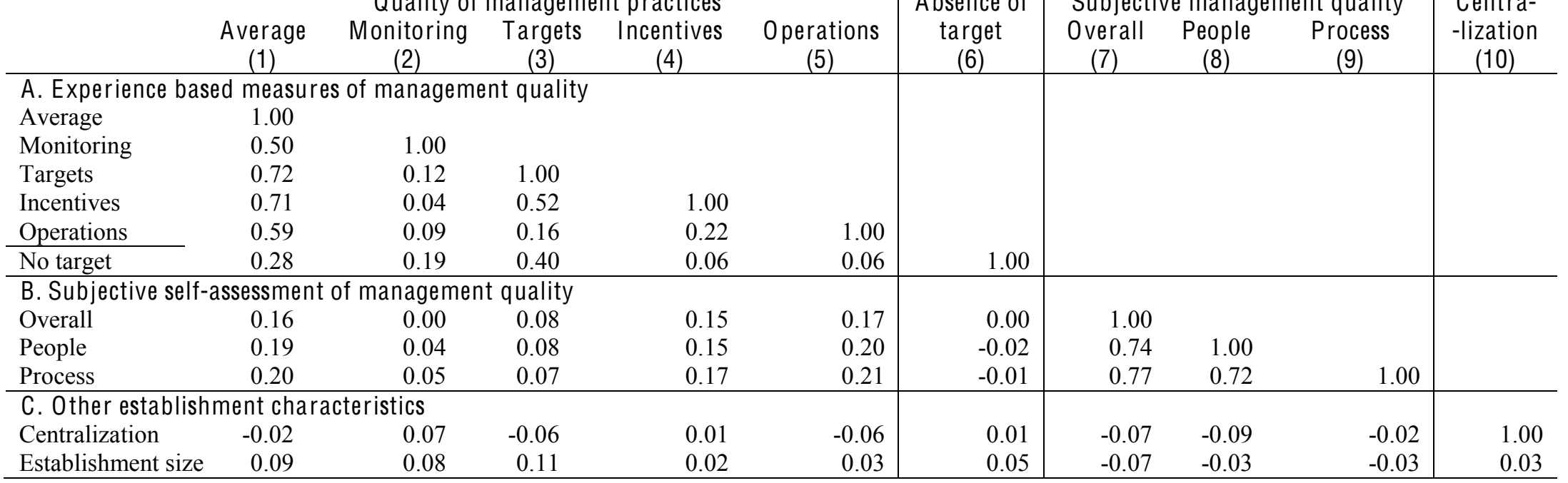

Note: The Table reports pair-wise linear correlations between different metric of the quality of management practices.

Source: MOI 2010 (EBRD-WB) and authors' computations. 